OCEAN DRILLING PROGRAM

LEG 114 SCIENTIFIC PROSPECTUS

SUBANTARCTIC SOUTH ATLANTIC

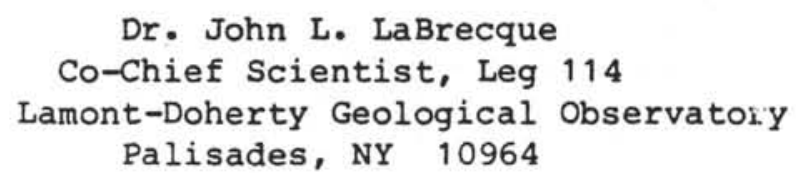

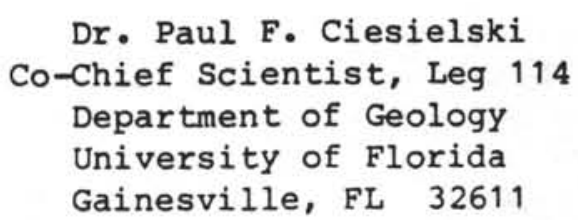
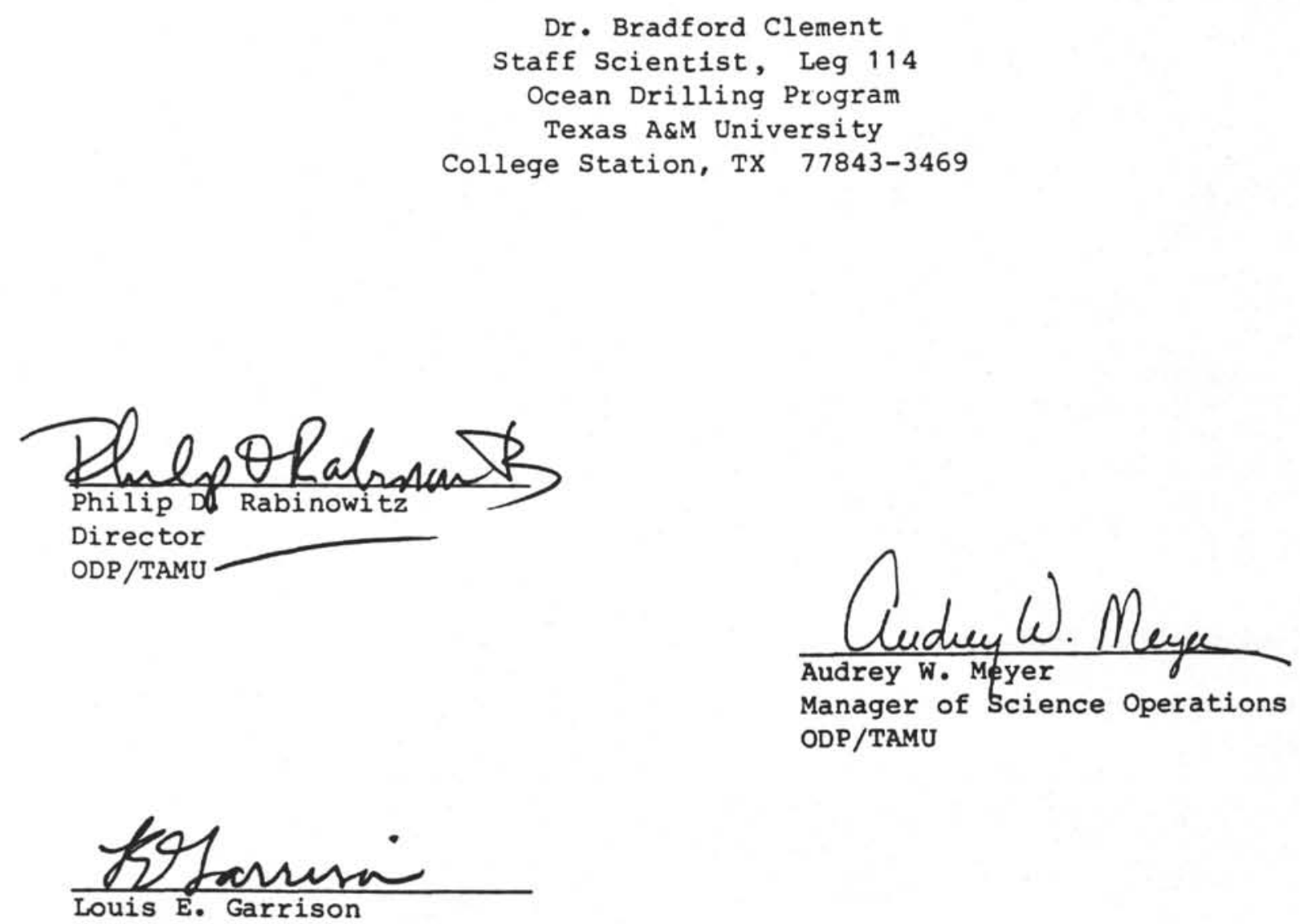

Deputy Director

ODP/TAMU

February, 1987 
Material in this publication may be copied without restraint for library, abstract service, educational or personal research purposes; however, republication of any portion requires the written consent of the Director, Ocean Drilling Program, Texas A\&M University, College Station, Texas, 77843-3469, as well as appropriate acknowledgment of this source.

Scientific Prospectus No. 14

First Printing 1987

Distribution

Copies of this publication may be obtained from the Director, Ocean Drilling Program, Texas A\&M University, College Station, Texas 77843-3469. In some cases, orders for copies may require a payment for postage and handling.

\section{DISCLA IMER}

This publication was prepared by the Ocean Drilling Program, Texas A\&M University, as an account of work performed under the international Ocean Drilling Program which is managed by Joint Oceanographic Institutions, Inc., under contract with the National Science Foundation. Funding for the program is provided by the following agencies:

Department of Energy, Mines and Resources (Canada)

Deutsche Forschungsgemeinschaft (Federal Republic of Germany)

Institut Francais de Recherche pour l'Exploitation de la Mer (France) Ocean Research Institute of the University of Tokyo (Japan)

National Science Foundation (United States)

Natural Environment Research Council (United Kingdom)

European Science Foundation Consortium for the Ocean Drilling Program (Belgium, Denmark, Finland, Iceland, Italy, Greece, the Netherlands, Norway, Spain, Sweden, Switzerland, and Turkey)

Any opinions, findings and conclusions or recommendations expressed in this publication are those of the author(s) and do not necessarily reflect the views of the National Science Foundation, the participating agencies, Joint Oceanographic Institutions, Inc., Texas A\&M University, or Texas A\&M Research Foundation. 


\section{INTRODUCTION}

Several fundamental questions remain regarding the evolution of global climatic, glacial, and oceanographic systems since the Late Mesozoic. The major driving forces for changes in these systems have been in the high southern latitudes where a number of tectonic events have led to the thermal isolation of Antarctica, the initiation and growth of the antarctic ice sheets, and the development of modern abyssal circulation.

Prior to the development of shallow and deep teleconnective passageways in the circum-antarctic, northward transport of cold surface and deep polar waters was restricted. The increase of thermal gradients in the southern hemisphere is linked to the development of the circum-antarctic circulation system (Kennett, 1977, 1978), first by the onset of deep water flow through the Tasman Seaway between Australia and Antarctica during the late Eocene, followed by the opening of the Drake Passage between South America and West Antarctica during the Oligocene (Barker and Burrell, 1977, 1982; LaBrecque and Rabinowitz, 1977; OMD Region 13 Synthesis, 1986). The result of a fully developed circum-antarctic current was thermal isolation of the antarctic continent by decoupling of the warm subtropical gyre systems from the antarctic margins. This led to the growth and expansion of the ice sheets on Antarctica and the development of the psychrosphere. Prior to the development of these passageways, Paleogene thermal gradients may have steepened at different rates within the Pacific, Indian Ocean, and Atlantic Basins. Critical to unraveling the Late Cretaceous to early Neogene paleoenvironmental evolution of the circum-antarctic is the recovery of well-distributed sedimentary sequences which can be assembled as meridional, latitudinal and depth transects.

The Ocean Drilling Program, recognizing the need and importance of additional high latitude drilling, has made a major commitment to Southern Ocean studies during the initial phase of the program. During 1987, ODP Legs 113 and 114 will sample the South Atlantic sector of the Southern Ocean. The sites proposed for these two cruises (Figure 1) will provide a broad regional sampling of the Indo-Atlantic and Weddell Basins with continuous coring techniques that minimize sediment disturbance.

Nearly continuous and undisturbed sequences recovered by the Advanced Piston Corer (APC) or the Extended Core Barrel (XCB) corer from the subantarctic and antarctic regions are required for the interpretation of high latitude climate and oceanographic dynamics. Only six previous DSDP cruises recovered subantarctic-antarctic sequences: Leg 28 (Southeast Indian Ocean and Ross Sea), Leg 29 (Southeast Indian Ocean), Leg 35 (Southeast Pacific), Legs 36 and 71 (Southwest Atlantic), and Leg 90 (Site 594, Southwest Pacific). Most holes of these legs were rotary drilled resulting in drilling disturbance and poor core recovery; other holes were sparsely sampled with large washed intervals in order to reach basement objectives. Only Sites 594 and 514 were cored with low disturbance techniques.

Proposed sites for ODP Legs 113 and 114 should provide a Late Mesozoic to Cenozoic record from the antarctic continental margin ( $72^{\circ} \mathrm{S}$ latitude) to the northern subantarctic ( $46^{\circ} \mathrm{S}$ latitude), over a wide range of paleo- and present water depths. A number of these sites are situated on basement 
Leg 114 Scientific Prospectus

page 2

highs where lengthy Upper Cretaceous to Neogene records of carbonatebearing pelagic sections will be recovered. The combined record from these sites is expected to provide the first detailed history of antarctic glacial conditions, the development of polar water masses, and their relationship to global climate and oceanographic evolution.

Leg 114 is scheduled to begin in East Cove, Falkland Islands on March 16, 1987, and end in Port Louis, Mauritius on May 14, 1987. During these 59 days, Leg 114 will have 36 days available for on-site operations to drill at least three high-priority sites (SA2 ALT A, SA3A, SA8C). Because of the prevalence of bad weather and sea conditions in this region and the associated uncertainties in scheduling, three contingency sites (SA5, SA6, and SA7) are included.

\section{OBJECTIVES}

I. Summary of Major Objectives

The drilling program for ODP Leg 114 will investigate the development and influence of teleconnective passageways to oceanic circulation within the Atlantic sector of the Southern Ocean. This general objective involves the interrelationship of the paleoceanographic record and the Mesozoic and Cenozoic regional geologic history. Three sites (SA5, SA6 and SA 8 ) have primary tectonic objectives regarding the evolution of the Malvinas Plate, the Islas Orcadas and Meteor Rises, and the interbasin gateway between the South Atlantic and Weddell Basins (LaBrecque and Hayes, 1979; OMD Region 13 Synthesis, 1986). The two prime deep water sites (SA2 and SA3) and a contingency site (SA7) will provide the record of a deep water passageway between the Weddell Basin and South Atlantic since the early Paleogene. Site SA2 will also provide a record of the Late Cretaceous deep water environment prior to the development of the gateway relief.

Some of the specific objectives to be addressed during Leg 114 include:

A. Regional geologic history

1. Examine the geochemical development of oceanic crust along a flow line which commences with the initial rifting of oceanic crust and the generation of dual aseismic ridges and proceeds to steady state seafloor spreading.

2. Determine the subsidence rates for the Northeast Georgia Rise (fossil arc Massif), Meteor and Islas Orcadas Rises (aseismic ridges).

3. Determine basement age at sites SA2, SA3, SA5, SA6, and SA 8 to check estimated basement ages and associated models.

4. Determine the geologic history of the Northeast Georgia Rise and its relationship to the Southern Andean Orogeny and the development of the Scotia Sea.

B. Paleoceanographic history of the subantarctic South Atlantic and its relationship to the glacial development of Antarctica and regional tectonic events.

1. Document the paleoenvironmental evolution from the Late Cretaceous to the modern ocean for the passageway linking the South Atlantic 
and Weddell Basins.

2. Determine Paleogene latitudinal and vertical thermal gradients in the Subantarctic South Atlantic.

3. Document the establishment of the Antarctic Circumpolar Current (ACC) as a result of the opening of the Drake Passage.

4. Complete the record of middle-late Cenozoic Polar Front migrations.

5. Interpret antarctic climate and ice volume history.

\section{Discussion of Major Objectives}

A. Regional geologic history and the nature of aseismic ridges.

1. Examine the geochemical development of oceanic crust along a flow line which commences with the initial rifting of oceanic crust and the generation of dual aseismic ridges and proceeds to steady state sea floor spreading.

The Islas Orcadas and Meteor Rises are aseismic ridges that were generated during the early Paleogene at the site of a propagating rift. As such they are analogues of the Walvis Ridge-Rio Grande Ridge system which was also generated during the Late Cretaceous (Chron C34 - C31) readjustment in seafloor spreading. Sites SA6, SA3, SA7, and SA8 will develop a petrologic data set analogous to the Walvis Ridge Leg 73-74 transect. This will monitor the development of the magma chamber along a flow line from a spreading center creating anomalous crustal structure to steady state sea floor spreading.

2. Determine the subsidence rates for the Northeast Georgia Rise (fossil arc Massif), the Meteor and Islas Orcadas Rises (aseismic ridges).

The recovered sediments from Sites SA5, SA6, and SA8 will track the rate of subsidence for these oceanic plateaus. The subsidence rates may be interpreted in terms of the lithospheric stress and thermal state and could lead to a better understanding of the mechanisms that generated these features. The rates of subsidence are also important in describing the development of the oceanic gateway between the South Atlantic and the Weddell Basin.

3. Determine basement age at Sites SA2, SA3, SA5, SA6, and SA8 to check estimated basement ages and associated models.

To date, the existing magnetic anomaly data for the region are sparse and interpretations of the data set are subject to major uncertainties. The results of basement ages at Sites SA2, SA2 ALT, SA5, SA6 and SA8 will greatly improve the certainty of paleogeographic reconstructions. Sites SA3 and SA7 are well positioned on clear magnetic anomalies. The basement ages at these sites could contribute to magneto-biostratigraphic time scale development. We hope, however, that the magnetostratigraphy of the recovered sequences will be much more valuable in this respect than basement ages. 
Leg 114 Scientific Prospectus

page 4

4. Determine the geologic history of the Northeast Georgia Rise and its relationship to the Southern Andean Orgeny and the development of the Scotia Sea.

LaBrecque and Hayes (1979) documented the existence of the Malvinas Plate and its motion with respect to Africa in the Late Cretaceous. The extent of the Malvinas Plate in the Late Cretaceous is uncertain because of the limited amount of geophysical data in the region and because most of the Mesozoic oceanic crust from the western Indo-Atlantic Basin (except for that in the Georgia Basin) has been removed as the South Sandwich subduction zone has advanced. The regional geology of the North Scotia Ridge and the Northeast Georgia Rise may allow us to reconstruct the Mesozoic history of the Northern Indo-Atlantic Basin. The Andean Orogeny generated a mid-Cretaceous accretionary prism which extends $2000 \mathrm{~km}$ from Tierra del Fuego to South Georgia. The North Scotia Ridge may be interpreted as the remains of an accretionary prism which has subsequently been dissected by the generation of the Scotia Sea since the Oligocene. Plate tectonic analysis and marine geophysical data show that the Northeast Georgia Rise may have been a portion of the convergent boundary between the Malvinas Plate and the South American Plate which was active during the Southern Andean Orogeny. Figure 2 (from the OMD Region 13 Atlas) displays the geometry and the amount of convergence predicted between the Malvinas Plate and the South American Plate during the Late Cretaceous. The model predicts nearly $1000 \mathrm{~km}$ of northward convergence in Tierra del Fuego (if the Malvinas Plate extended as far west as Tierra del Fuego), as well as the proper sense of motion to generate the Northeast Georgia Rise. This model can therefore explain the Southern Andean Orogeny and link the North Scotia Ridge sediments to Weddell Basin development. In other words, the sediments of the North Scotia Ridge were accreted from the opposing (northern) flank of a spreading center which generated the present-day Weddell seafloor (Figures 3-6). The sediments now accreted in the North Scotia Ridge could represent deep water equivalents of the Falkland Plateau sequences recovered by DSDP Sites 327, 329, 330, 511, and 512 .

Contingency Site SA5 will recover sediments from the Northeast Georgia Rise to establish the geologic history of the Rise and to provide a link between the region's marine data sets and land geology for the Mesozoic. The crucial test in linking the Malvinas Plate model to the Southern Andean Orogeny is the development of a time scale for subduction at the Northeast Georgia Rise. This time scale could then be compared to the timing of geologic events observed in the Southern Andean Cordillera. Drilling at SA5 is the best means to develop these objectives.

B. Paleoceanographic history of the subantarctic South Atlantic and its relationship to the glacial development of antarctic and regional tectonic events.

1. Document the paleoenvironmental evolution from the Late Cretaceous to modern ocean for the critical passageway linking the South Atlantic and Weddell Basins. 
The subantarctic region is of critical importance for an understanding of paleoenvironmental interaction between the Weddell Basin and the Atlantic Basin to the north. Tectonic development in the subantarctic region during the Cretaceous and Paleogene profoundly restricted deep and intermediate water mass connections between the southern and northern areas. Figure 6 displays the Campanian reconstruction of the Atlantic sector, while Figures 3 through 5 display reconstructions of the proposed drilling region for the Late Cretaceous, late Paleocene, and middle Eocene. Circulation between the South Atlantic and the Weddell Basin was interupted by the generation of the major relief along the Malvinas Plate boundaries during the Late Cretaceous. Following a jump in spreading centers, a gateway formed between the South Atlantic and Weddell Basins as thermal subsidence and seafloor spreading separated the Islas orcadas and Meteor Rises. It is likely that the interbasin connections remained relatively shallow throughout much of the Paleogene.

The Falkland/Agulhas interbasin passageway is critical because most bottom water that now enters the South Atlantic from the Weddell Sea flows through this passageway. Present-day flow is strongly affected by the regional morphology. Therefore, we expect that the influence of the regional relief increased during earlier periods in the basin's history as the gateway became more restricted. The age, subsidence, and separation history of the aseismic ridges are analogues to the Greenland-Iceland-Faroes Ridge and are no less important in understanding the development of Atlantic-Weddell-Indian paleoenvironment.

Sites SA3 and SA7 were selected on middle Eocene (Chron C23 to C20) oceanic crust on the flanks of the Mid-Atlantic Ridge. Each site is located in the earliest portion of the gateway that formed between these rises. The sedimentary sequences in these two locations are expected to provide a history of the re-establishment of intermediate to deep water mass connections between the Weddell and Atlantic Basins during the middle Cenozoic. This history should provide an important basis with which to interpret South Atlantic Basin sediments of Eocene and Oligocene age.

Site SA2 is located to the south of the gateway and northeast of the South Sandwich Arc. This site is located on Cretaceous crust which predates the formation of the Is las Orcadas and Meteor Rises and the gateway which formed between them in the Eocene. Comparison of the sedimentary sequence at this site with that from within the gateway (SA3 or SA7) and previous South Atlantic sites to the north of the gateway should provide a complete history of the Late Cretaceous to Neogene interbasin circulation.

2. Determine Paleogene and early Neogene latitudinal and vertical thermal gradients in the subantarctic South Atlantic.

A major objective of Leg 114, and the previous Leg 113 to the Weddell Sea, is to recover suitable sequences which may be used to reconstruct the record of steepening latitudinal gradients in high latitudes during the Cenozoic. Previous studies have shown that the 
Leg 114 Scientific Prospectus

page 6

tropics remained near constant temperature or may have warmed slightly during the Cenozoic (Savin et al., 1985). Even though the greatest temperature changes in the Cenozoic oceans occurred at high latitude, the thermal history of this region is poorly known because of the paucity of high latitude sequences suitable for isotopic study. The sequences to be drilled by Legs 113 and 114 will provide a latitudinal transect extending from $46^{\circ} \mathrm{S}$ to $72^{\circ} \mathrm{S}$ with which to evaluate the subantarctic-antarctic thermal gradients.

Keigwin and Corliss (1986) presented a synthesis of isotopic results for the middle Eocene through Oligocene (Figure 7 ) and concluded that no change occurred in latitudinal oxygen isotopic gradient and that the Paleogene gradient was less than half that of the Holocene gradient. It appears that the tropics and subtropics underwent little change during the Cenozoic and most temperature change was at high latitudes.

The greatest shortcoming in thermal gradient studies to date is the dearth of Paleogene oxygen isotopic data from latitudes greater than $50^{\circ} \mathrm{S}$ (Figure 7 ). At present, Paleogene oxygen isotopic records at higher latitudes are limited to two sites: Site 277 (52.13's) and Site $511\left(51^{\circ} \mathrm{S}\right)$. Integration of the antarctic (Leg 113) and subantarctic (Leg 114) oxygen isotopic data into the existing global syntheses (Keigwin and Corliss, 1986; Murphy, 1985) will provide the first complete transect of planktonic oxygen isotopic records from the polar regions to the equator.

Sites SA5, SA6, and SA8 are expected to provide a Late Cretaceous to Miocene carbonate record. These sites therefore will provide a rich resource for paleoenvironmental and isotopic analysis. Piston cores indicate that we will obtain Messinian carbonates from Site SA6, the only such site known in the Southern Ocean. Because of a severe hiatus, much of the Late Cretaceous and Paleogene sediments from the Falkland Plateau DSDP sites are missing. Sites SA6 and SA8, which are located on shallow pediments in the mid-basin, should have lengthy sections of Paleogene and upper Maestrichtian carbonate. Deep water Sites SA2, SA3, and SA 7 will recover Eocene to Oligocene carbonate because the location of the Eocene spreading center should be above the carbonate compensation depth (CCD) during this period. The younger Sites SA3 and SA7 may have carbonate records that continue into the early Miocene. Sites SA7 and SA8 will return information on the meridional thermal gradients.

The primary sites form a depth transect which spans a range from approximately 1600-4700 m. These sites should intersect the major water masses of the Paleogene Ocean between the photic zone and approximately $3700 \mathrm{~m}$ below sea level. Oxygen and carbon isotopic studies of benthic foraminifers from Leg 114 sites should further elucidate the vertical water mass structure of the Paleogene to early Neogene subantarctic and the evolution of the modern water masses (Antarctic Intermediate Water, Circumpolar Deep Water, Antarctic Bottom Water, Figure 8) or their precursors. It is hoped that carbon isotope analyses will yield source signatures for these water masses and therefore help in determining the development of teleconnective passageways. 
Questions that may be addressed through isotopic studies of Leg 114 sequences include:

(1) What was the history of the steepening of latitudinal temperature gradients in the South Atlantic during the Paleogene?

(2) What is the meridional dependence of temperature gradients?

(a) Did latitudinal thermal gradients steepen between the subantarctic and temperate regions during the Oligocene as observed in the Southwest Pacific (Murphy and Kennett, 1985)?

(b) How did the opening of the Drake Passage in the Oligoceneearly Miocene affect latitudinal thermal structure of the high latitude South Atlantic?

(c) How does the history of Paleogene temperature change compare between subantarctic Leg 114, antarctic Leg 113, and subantarctic Site 277?

(3) Did the planetary temperature gradient, especially at high latitude, change appreciably across the Eocene/Oligocene boundary?

(4) How do the Paleogene latitudinal thermal gradients compare with those during the Neogene and Holocene?

(5) Was salinity of surface waters at high latitudes reduced during the Paleogene because of the production of warm saline bottom water at low latitudes as suggested by Poore and Matthews (1984)?

(6) When did the Polar Front (Antarctic Convergence) become a strong, conspicuous feature of the high latitude Southern Ocean?

(7) How did changing thermal gradients during the Paleogene affect latitudinally-zoned biogeographic provinciality and diversity gradients?

3. Document the establishment of the Antarctic Circumpolar Current.

The opening of the Drake Passage between South America and West Antarctica strongly influenced Cenozoic climate because it allowed the complete development of the Antarctic Circumpolar Current (ACC) and thermal isolation of Antarctica. Barker and Burrell (1977, 1982) concluded that coherent spreading began in the Drake Passage at $29 \mathrm{Ma}$ (Chron C8). However, more recent data from the western Scotia Sea clearly show that seafloor spreading commenced prior to Chron $\mathrm{ClO}$ (LaBrecque and Rabinowitz, 1977; OMD Regional Synthesis 13). Even following formation of the gap, the vastly different tectonic setting in the Scotia Sea and the more compact arrangement of continental fragments around its margins may have greatly impeded and altered the early to middle Miocene flow of the ACC. Certainly the progressive cooling since the Eocene may be attributed to Drake Passage opening. Several paleoenvironmental events span the stratigraphic record within the oligocene and Miocene which may be attributed to events in the opening of the Drake Passage.

What of precursors to the Drake Passage opening? Wise et al. (1985) discuss a major erosional event of Late Cretaceous to Paleogene age on the Falkland Plateau which is difficult to explain in the context of an enclosed Weddell Basin.

Through examination of the thermal history (isotopic record) and sedimentologic and micropaleontologic characteristics of Leg 114 sites 
we will attempt to better constrain the opening of the Drake Passage and the changes in the position and volume of transport of the ACC between the Pacific and Atlantic.

\section{Document Antarctic Polar Front history.}

Leg 114 sites represent a southward extension of the longitudinal traverse begun with DSDP Sites 513 and 514. The traverse is intended to monitor the development and migration of surface water masses and the migrational history of the Polar Front. The continuation of the transect initiated at sites 513 and 514 is essential to determining the development of mid-latitude water masses and the long- and short-term migrations of the Polar Front and surface water masses. To date, the only detailed record of the Polar Front migration history is the Pliocene record of Site 514 (Ciesielski and Grinstead, 1986). Sedimentologic and quantitative micropaleontologic studies of Leg 114 sites should provide a valuable record of the latitudinal migrations of this sensitive oceanographic boundary separating antarctic and subantarctic water masses.

\section{Interpret antarctic climate and ice volume history.}

The greatest gap in knowledge of the development of Cenozoic climate and glacial systems is in the southern high latitudes. To a considerable degree this is the result of a paucity of continuous and undisturbed marine sequences between the Antarctic continent and the mid- to low-latitude regions. This has led to growing controversy over the history of the formation and subsequent fluctuations in the Antarctic ice sheets (Shackleton and Kennett, 1975; Miller and Fairbanks, 1985; Matthews and Poore, 1980; Poore and Matthews, 1984).

Existing records of paleoenvironmental conditions in the Antarctic and subantarctic regions come from widely dispersed localities, such as the Transantarctic Mountains, Ross Sea, Antarctic Peninsula, Dry Valleys of Antarctica, and a few DSDP sites which were in general discontinuously drilled. With few exceptions these sequences represent brief intervals of time and their stratigraphic ages are poorly constrained.

Elucidating the climatic and glacial history of Antarctica requires obtaining a more detailed stratigraphic representation from several regions around the antarctic continent. Prior to the Neogene, conditions along the continental margins must have differed from basin to basin owing to the absence of the ACC, the difference in timing of the opening of the tectonic portals, and the probable absence of a west Antarctic ice sheet (Ciesielski et al., 1982). ODP legs will provide the first complete transect of sites through the antarctic-subantarctic regions of a single sector of the Southern Ocean. From the results of these legs, when combined with future results from 1988 drilling in the Kerguelen Plateau region of the Indian Ocean and possibly additional drilling in the Pacific sector of the Southern Ocean, a complete history of circum-antarctic climatic and glacial history may finally emerge. 


\section{DRILLING PROGRAM}

During ODP Leg 114, JOIDES Resolution will transit across the subantarctic South Atlantic, drilling three sites (SA2 ALT A, SA3A, and $\mathrm{SA} 8 \mathrm{C}$ ) in route. Alternate sites have been selected which may be drilled in the event that severe weather restricts operations at the prime sites. At SA2 ALT A and SA3A, we plan to core using the APC to refusal and then to continue coring into basement with the XCB. Second APC holes are planned for these two sites. The sediment sequence at SA8C is too thick to core using the XCB. Because basement at SA $8 \mathrm{C}$ is a prime objective, we plan to rotary core to basement at this site and then use the APC to core the upper interval of the sequence. Two logging runs, using the standard Schlumberger tool combinations, will be made at each site. Up to three days during Leg 114 will be devoted to testing the Navidrill coring system. 
Leg 114 Scientific Prospectus page 10

REFERENCES

Barker, P.F., and Burrell, J., 1977. The opening of Drake Passage. Mar. Geol., 25: 15-344.

Barker, $\overline{P . F}_{.}$, and Burrell, J., 1982. The influence upon Southern Ocean circulation, sedimentation, and climate of the opening of Drake Passage. In Craddock, C. (Ed.), Antarctic Geoscience: Madison, WI (Univ. Wisconsin Press), 377-385.

Ciesielski, P.F., and Grinstead, G.P., 1986. Pliocene fluctuations of the Antarctic Convergence in the southwest Atlantic. Paleoceanography, $1: 197-232$.

Ciesielski, P.F., Ledbetter, M.T., and Ellwood, B.B., 1982. The development of Antarctic glaciation and the Neogene paleoenvironment of the Maurice Ewing Bank. Mar Geol., 46:1-51.

Gordon, A.L., 1971. Oceanography of Antarctic Waters. In Antarctic Research Series: Washington, Am. Geophys. Union, 15: 169-203.

Keigwin, L.D., Jr., and Corliss, B.H., 1986. Stable isotopes in late middle Eocene to Oligocene foraminifera. Geol. Soc. Am. Bull., 97: 335-345.

Kennett, J.P., 1977. Cenozoic evolution of Antarctic glaciation, the circum-Antarctic Ocean, and their impact on global paleoceanography. J. Geophys. Res., 82:3843-3860.

Kennett, J.P., 1978. The development of planktonic biogeography in the southern ocean during the Cenozoic. Mar. Micropaleontol., 3: $301-345$.

LaBrecque, J.L., and Hayes, D.E., 1979. Seafloor spreading in the Agulhas Basin. Earth Planet. Sci. Lett., 45:411-428.

LaBrecque, J.L., and Rabinowitz, P.D., 1977. Magnetic Anomalies--Argentine Continental Margin, Argentine Basin, North Scotia Ridge, Falkland Plateau: AAPG Spec. Map Ser.

Ladd, J.W., 1974. South Atlantic seafloor spreading and Caribbean tectonics [Ph.D. Thesis]. Columbia Univ., New York.

Matthews, R.K., and Poore, R.Z., 1980. Tertiary 180 record and glacialeustatic sea level fluctuations. Geology, 8:501-504.

Miller, K.G., and Fairbanks, R.G., 1985. Oligocene to Miocene carbon isotope cycles and abyssal circulation changes. In The Carbon Cycle \& Atmospheric CO2: Natural Variations, Archean to present: Washington (Am. Geophys. Union), AGU Geophys. Monogr., 32:469-486.

Murphy, M.G., 1985. A model of oceanic circulation in the Oligocene: oxygen isotopic evidence [M.S. thesis]. Univ. Rhode Island.

Murphy, M.G., and Kennett, J.P., 1985. Development of latitudinal thermal gradients during the oligocene: oxygen isotope evidence from the Southwest Pacific. In Init. Repts. DSDP 90: Washington (U.S. Govt. Printing office), $13 \overline{47}-1360$.

OMD Region 13 Synthesis, 1986. South Atlantic Ocean and Adjacent Continental Margin Atlas $\overline{13, \mathrm{~J}} . \overline{\mathrm{L} .}$ LaBrecque (Ed.): Mar. Sci. Int., Woods Hole, MA.

Poore, R.Z., and Matthews, R.K., 1984. Oxygen isotope ranking of late Eocene and Oligocene planktonic foraminifers: Implications for Oligocene sea-surface temperatures and global ice volume. Mar. Micropaleontol., 9:111-134.

Savin, S.M., Abel, L., Barrera, E., et al., 1985. The evolution of Miocene surface and near-surface marine temperatures: oxygen isotopic evidence. In J.P. Kennett (Ed.), The Miocene Ocean: Geol. Soc. Am. 
Leg 114 Scientific Prospectus

page 11

Mem. 163.

Sverdrup, H.U., Johnson, N.W., and Fleming, R.H., 1942. The Oceans: Englewood Cliffs, NJ (Prentice-Hall).

Shackleton, N.J., and Kennett, J.P., 1975. Paleotemperature history of the Cenozoic and the initiation of Antarctic glaciation: Oxygen and carbon isotope analyses in DSDP Sites 277, 279, and 281. In Kennett, J.P., Houtz, R.E., et al., Init. Repts. DSDP 29: Washington (U.S. Govt. Printing office), 743-755.

Wise, S.W., Gombos, A.M., and Muza, J.P., 1985. Cenozoic evolution of polar water masses, Southwest Atlantic Ocean. In Hsu, K.J., and Weisert, J.J. (Eds.), South Atlantic Paleoceanography: Cambridge (Cambridge Univ. Press), 283-324. 
Leg 114 Scientific Prospectus

page 12

\section{FIGURE CAPTIONS}

Figure 1. Locations of proposed ODP sites for the Weddell Sea (Leg 113 -"W" prefix) and subantarctic drilling (Leg 114 -- "SA" prefix).

Figure 2. Detail of Figure 6D at the Campanian/Santonian boundary (Chron C34). Spreading center location determined from magnetic anomaly locations. Convergence vectors show direction and total motion during Chrons C34 and C31 based on the poles of rotation determined from LaBrecque and Hayes (1979) and Ladd (1974). The bases of the convergence vectors are plotted along the North Scotia Ridge and the Northeast Georgia Rise. Note that total convergence may have reached $1000 \mathrm{~km}$ near Tierra del Fuego from Santonian to Maestrichtian time. Polarity of the subduction zone was likely southward-dipping along the North Scotia Ridge and westward-facing along the Northeast Georgia Rise.

Figure 3. Reconstruction of the subantarctic sites for the Late Cretaceous. Spreading center locations based on magnetic anomaly locations and SEASAT gravity field. Supporting data are presented in the OMD Region 13 synthesis (1986).

Figure 4. Reconstruction of the subantarctic sites for the late Paleocene. Spreading center locations based on magnetic anomaly locations and SEASAT gravity field. Supporting data are presented in the OMD Region 13 synthesis (1986).

Figure 5. Reconstruction of the subantarctic sites for the middle Eocene. Spreading center locations based on magnetic anomaly locations and SEASAT gravity field. Supporting data are presented in the OMD Region 13 synthesis (1986).

Figure 6A. Jurassic reconstruction of Antarctica, South America and Africa. Presented in the OMD Region 13 synthesis (1986).

6B. Chron-CM13 or the Valanginian reconstruction. Presented in the OMD Region 13 synthesis (1986).

6C. Chron-CM1 or the Aptian reconstruction of the Southern Ocean. Note the opening of a seaway between East and West Antarctica. Presented in the OMD Region 13 synthesis (1986).

6D. Chron-C34 or the Campanian/Santonian reconstruction. Closure of the Trans-Antarctic Seaway is predicted. Relative motion of the Malvinas-South America plates has commenced. Subduction continues along the western margins of Antarctica and South America. Presented in the OMD Region 13 synthesis (1986).

6E. Early Paleogene reconstruction. The Bouvet Triple Junction jumps $800 \mathrm{~km}$ to the west. The Malvinas Plate ceases to exist and a barrier to Weddell-South Atlantic circulation forms as the Falkland-Agulhas Ridges are created. Relative motion between East and West Antarctica has terminated. Presented in the OMD Region 13 synthesis (1986). 
Leg 114 Scientific Prospectus

page 13

Figure 7. Average oxygen isotopic results in surface dwelling planktonic foraminifers (late Eocene and early Oligocene) plotted against paleolatitude without respect for hemisphere ("absolute" latitude). Eocene (solid data points) and Oligocene (open data points) are fitted with regression lines with slopes of 0.023 $(r=0.71)$ and $0.022 \% / 00(r=0.69)$ per degree latitude, respectively. Note that the Paleogene $18^{\circ}$ latitudinal gradient is considerably less than the Holocene gradient $(0.056$ o/oo per degree latitude). Keigwin and Corliss (1986) relate the significant difference between Eocene and Oligocene regression lines to effects of increased continental glaciation in earliest oligocene time (from Keigwin and Corliss, 1986).

Figure 8. Schematic representation of major surface and subsurface water masses of the high-latitude Southern Ocean (from Sverdrup et al., 1942; and Gordon, 1971). 


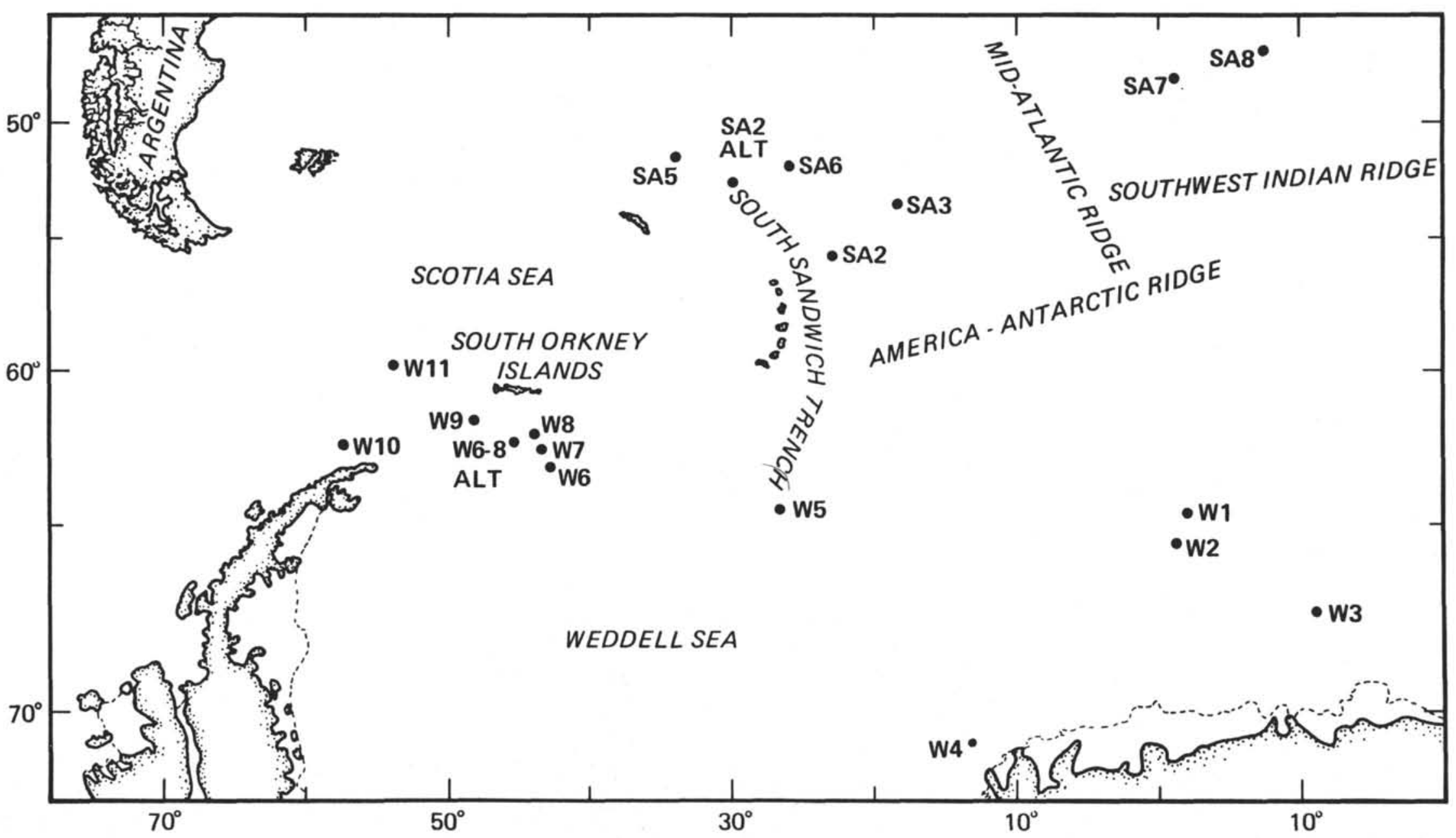

Figure 1. 


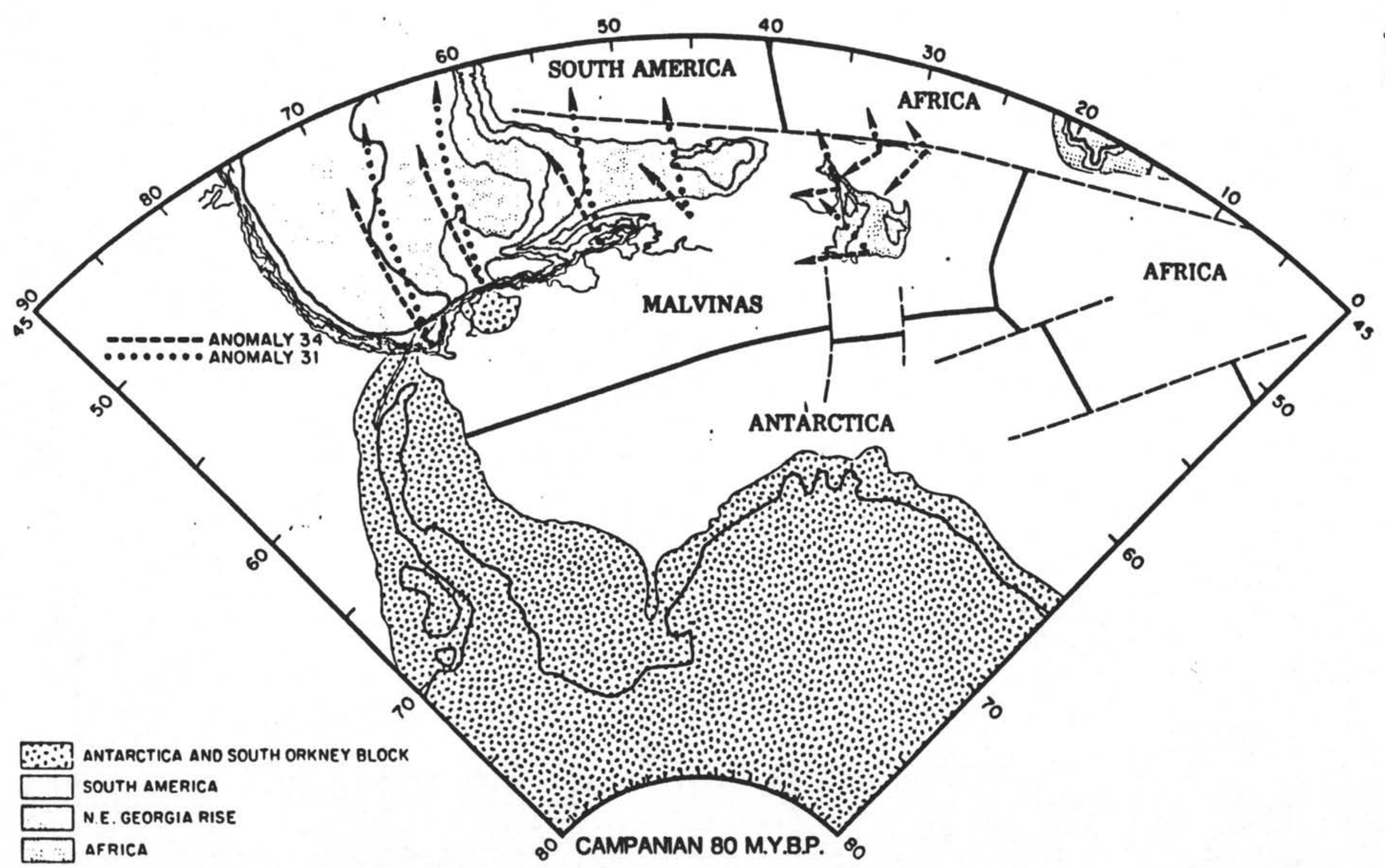

Figure 2. 


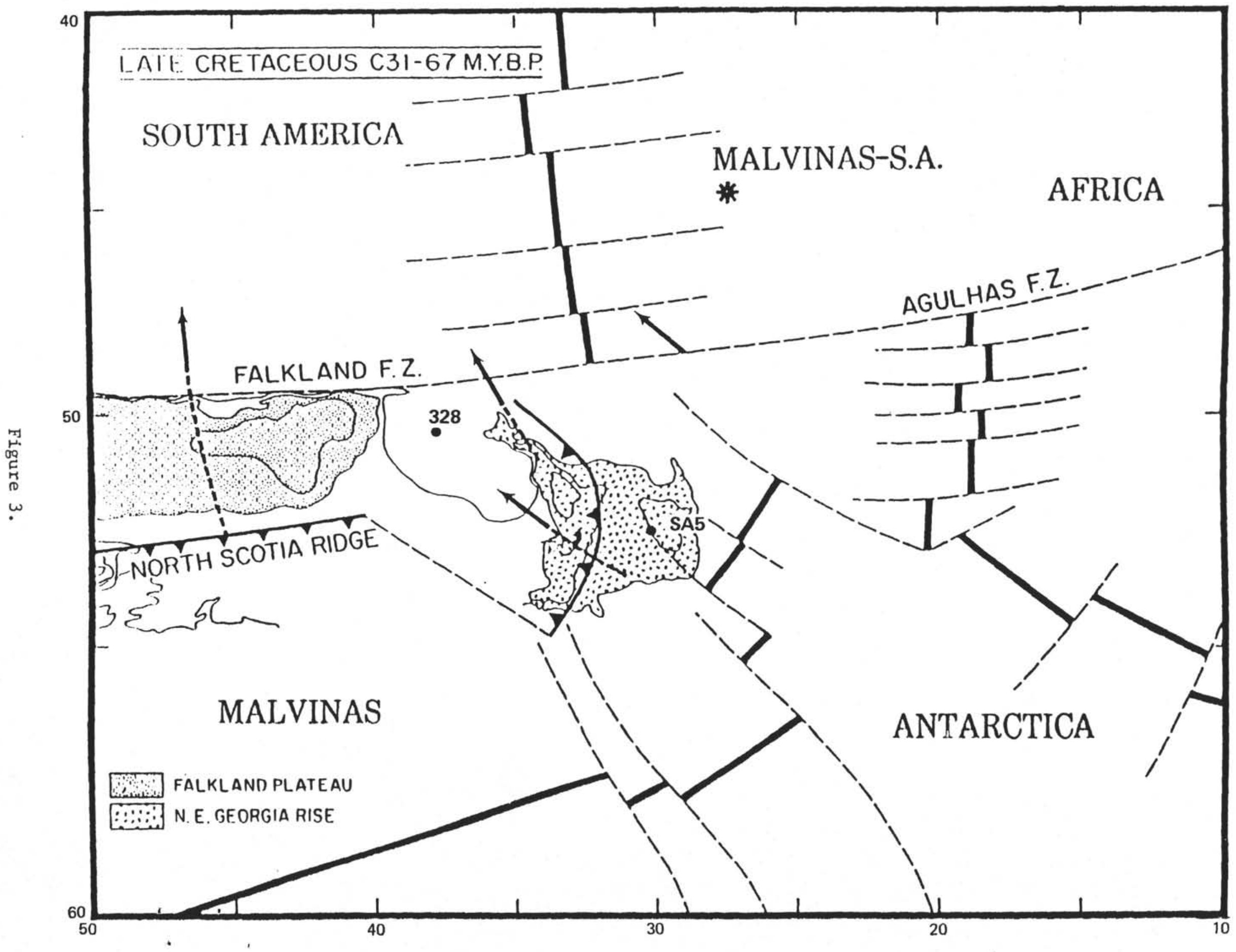




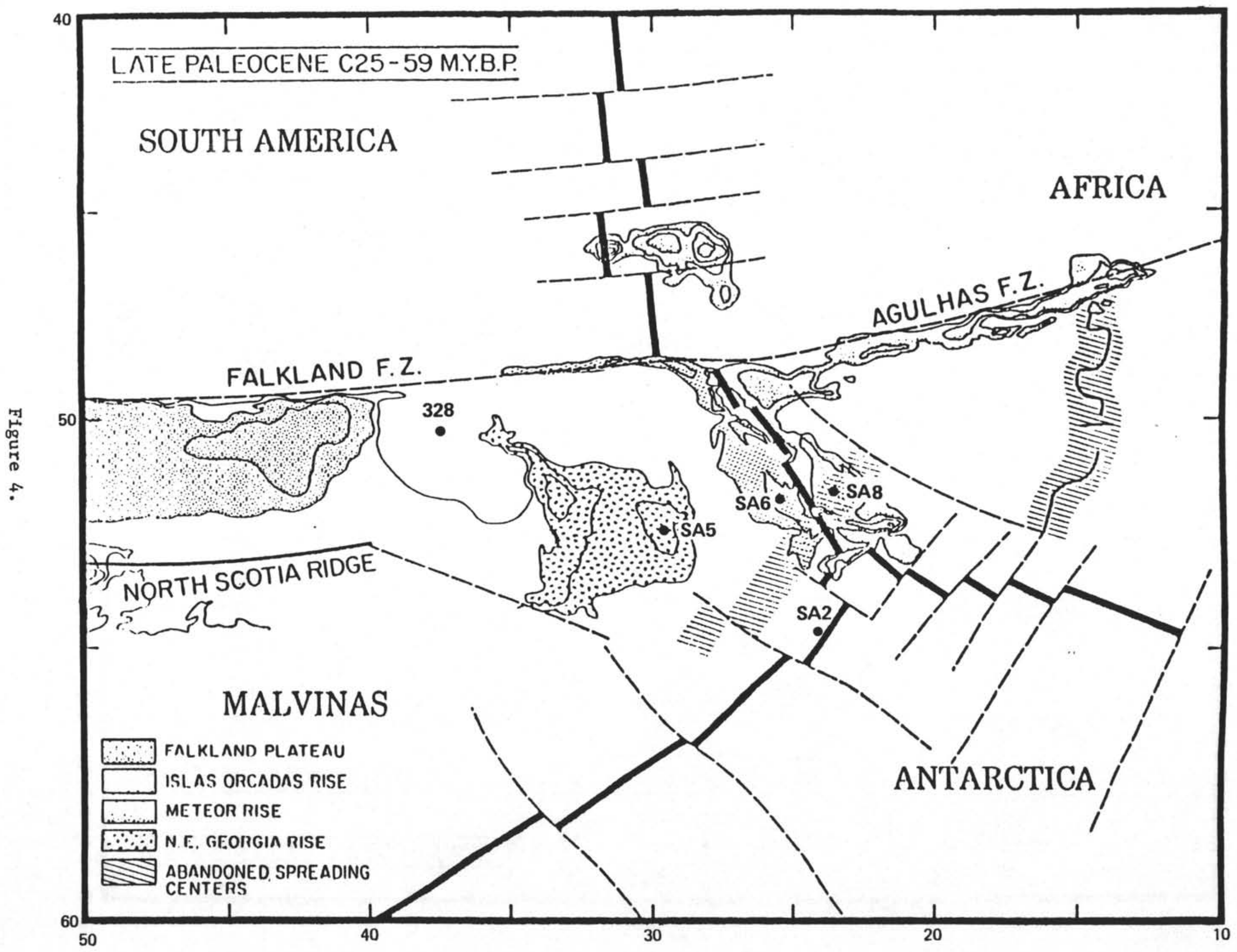




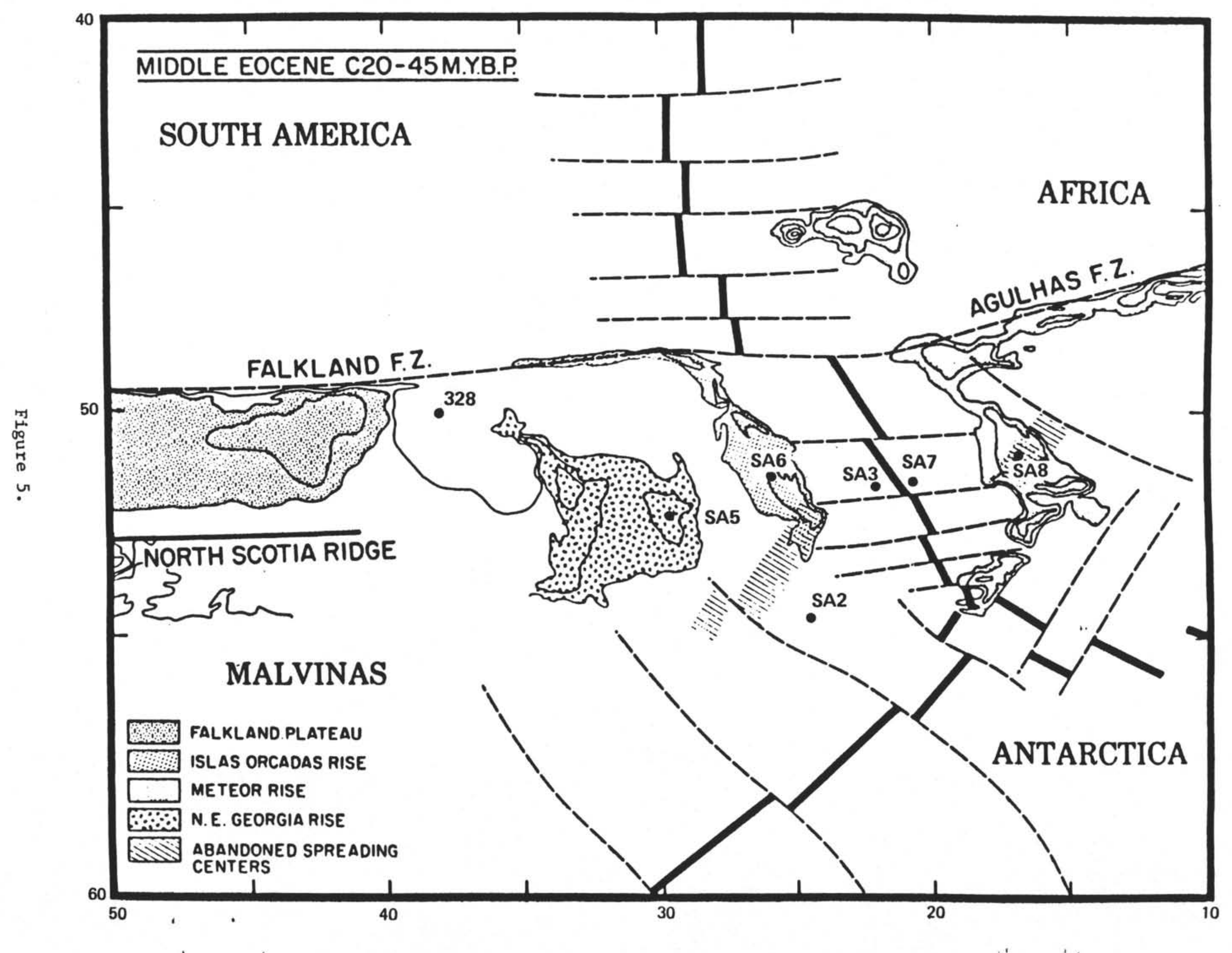


A

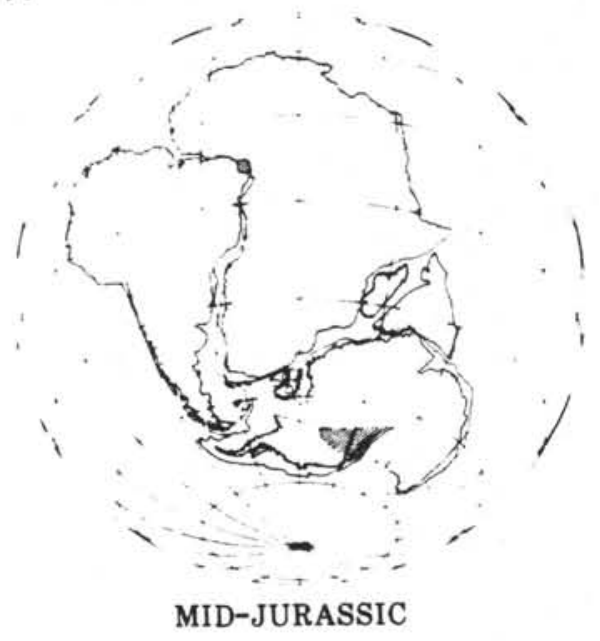

B

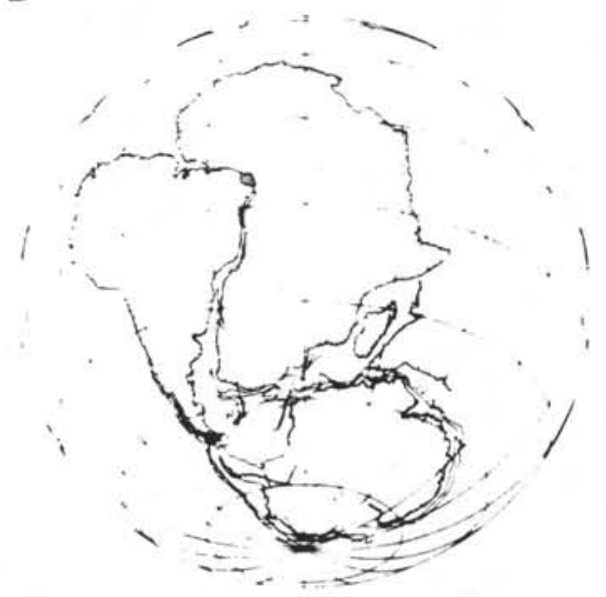

VALANGINIAN CM13
D

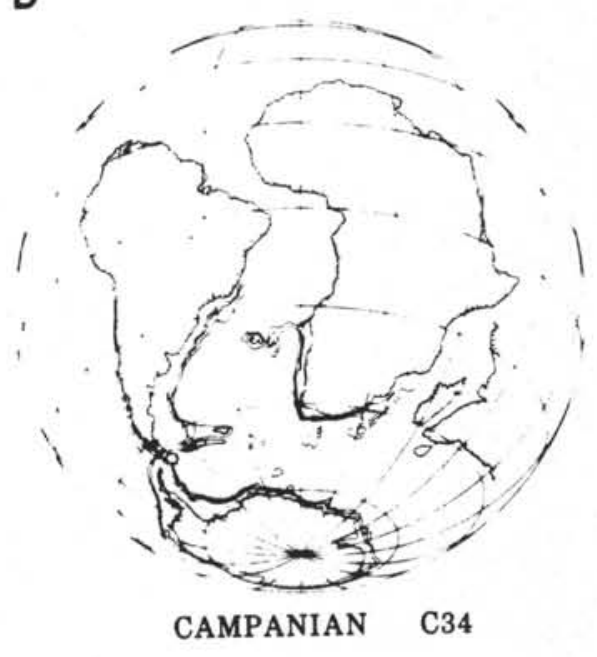

E

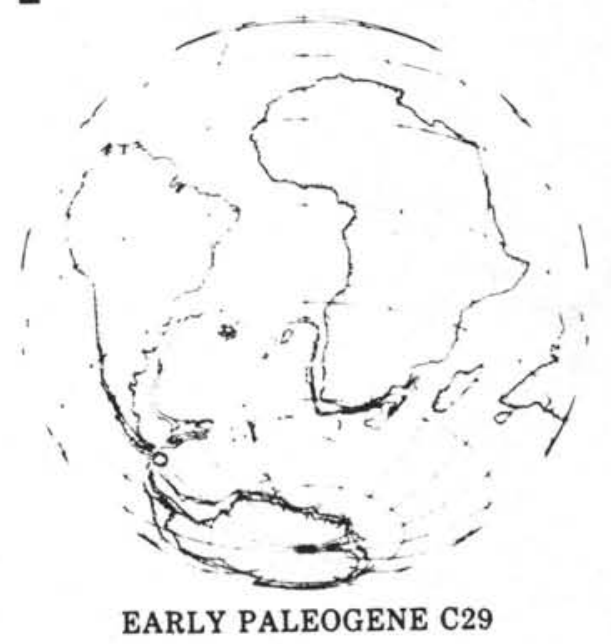

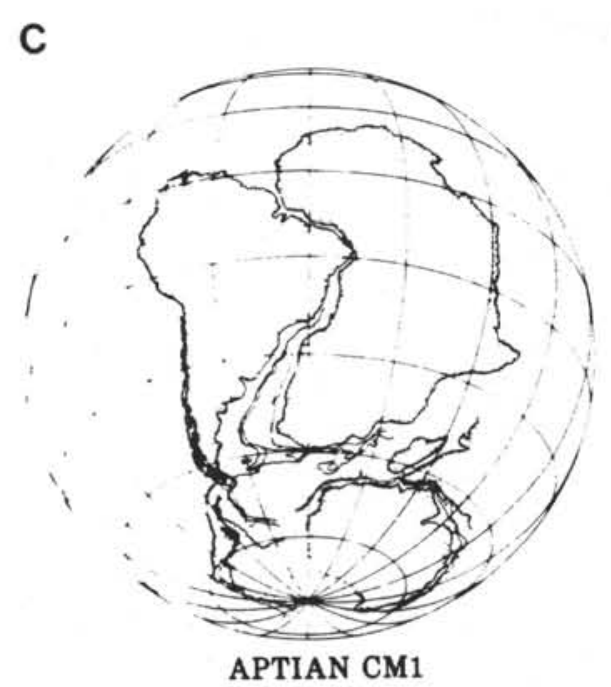

Figure 6. 


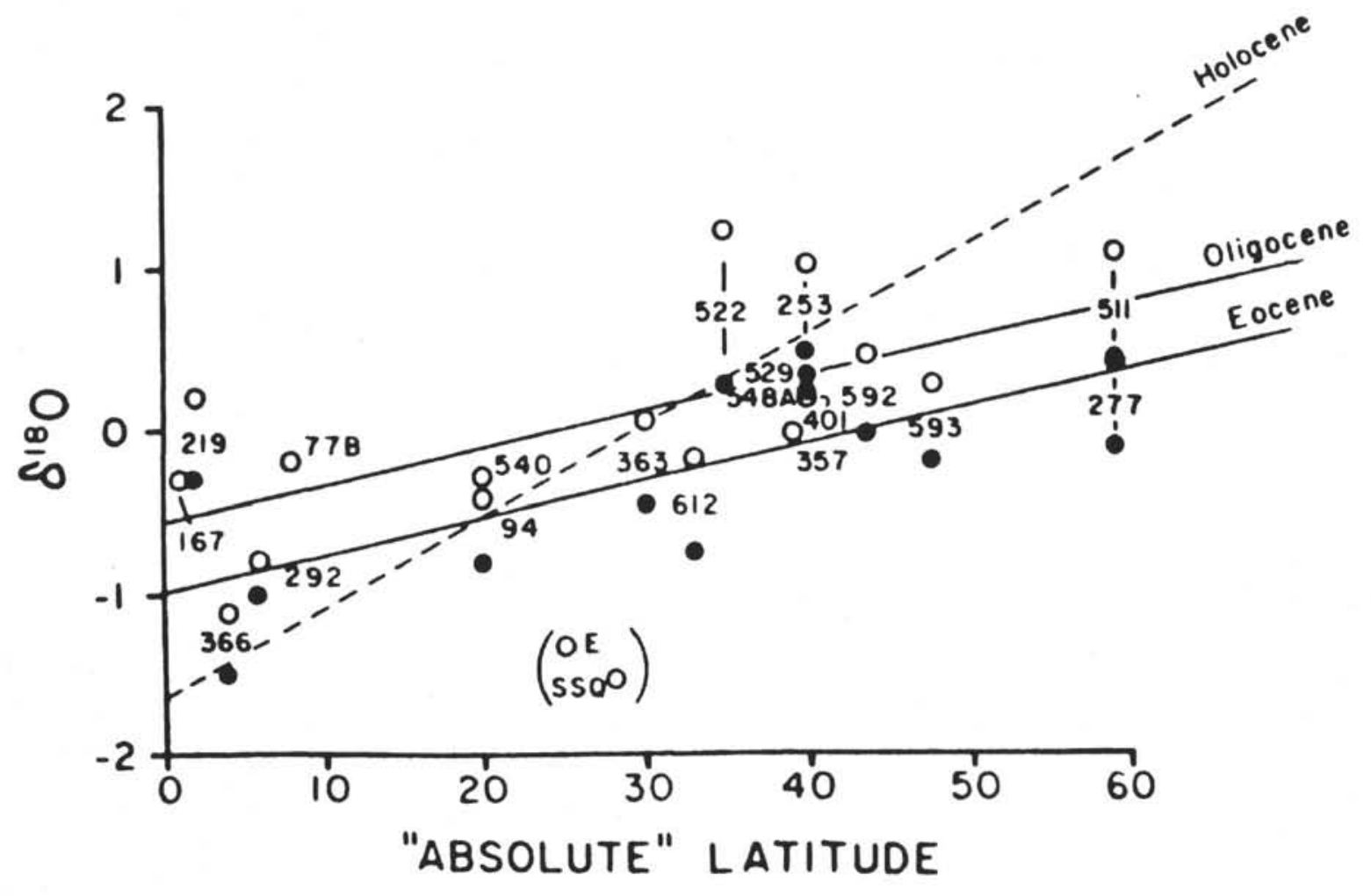

Figure 7. 


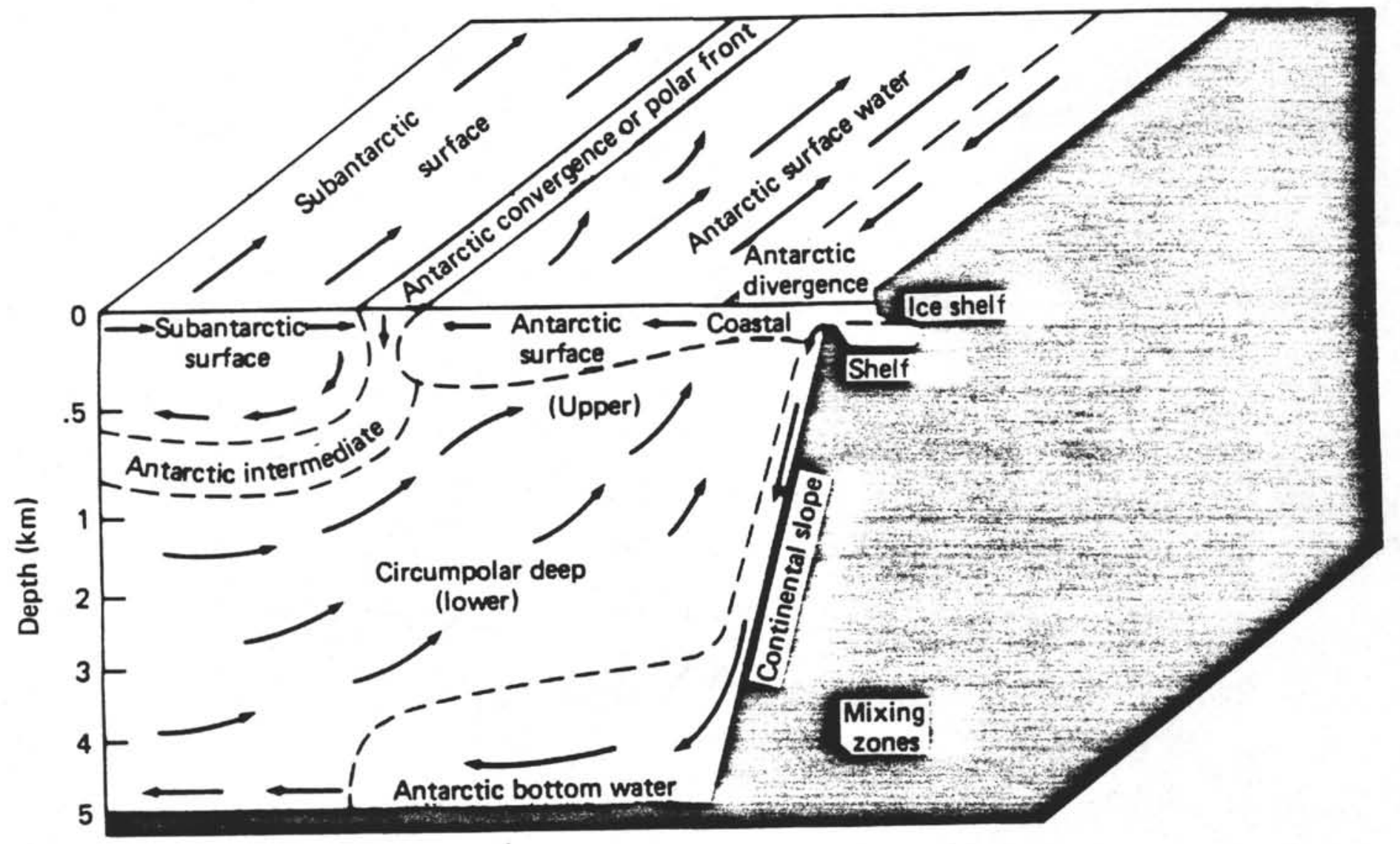

Figure 8. 
Table 1. Location of Proposed Sites for Leg 114

\begin{tabular}{|c|c|c|c|c|}
\hline & & & WATER & SEDIMENT \\
\hline SITE & LATITUDE & LONGITUDE & DEPTH (m) & THICKNESS (m) \\
\hline SA $2 A$ & $55.593^{\circ} \mathrm{S}$ & $22.101^{\circ} \mathrm{W}$ & 4275 & 600 \\
\hline SA 2B & $54.873^{\circ} \mathrm{S}$ & $23.734^{\circ} \mathrm{W}$ & 3975 & 600 \\
\hline SA 2C & $55.463^{\circ} \mathrm{S}$ & $23.450^{\circ} \mathrm{W}$ & 3975 & 600 \\
\hline SA2D & $55.852^{\circ} \mathrm{S}$ & $22.103^{\circ} \mathrm{W}$ & 4350 & 600 \\
\hline SA 2ALT-A & $51.542^{\circ} \mathrm{s}$ & $30.623^{\circ} \mathrm{W}$ & 3750 & 700 \\
\hline SA2ALT-B & $51.538^{\circ} \mathrm{S}$ & $30.309^{\circ} \mathrm{W}$ & 3600 & 350 \\
\hline SA $3 A$ & $51.987^{\circ} \mathrm{s}$ & $23.098^{\circ} \mathrm{W}$ & 4505 & 600 \\
\hline SA 3B & $52.623^{\circ} \mathrm{s}$ & $22.387^{\circ} \mathrm{W}$ & 4506 & 600 \\
\hline$S A 3 C$ & $51.626^{\circ} \mathrm{s}$ & $23.013^{\circ} \mathrm{W}$ & 4543 & 600 \\
\hline SA 3D & $51.838^{\circ} \mathrm{s}$ & $22.476^{\circ} \mathrm{W}$ & 4535 & 250 \\
\hline SA $5 A$ & $51.945^{\circ} \mathrm{s}$ & $33.088^{\circ} \mathrm{W}$ & 1604 & 800 \\
\hline SA $5 B$ & $51.550^{\circ} \mathrm{S}$ & $33.397^{\circ} \mathrm{W}$ & 1714 & 700 \\
\hline SA $5 \mathrm{C}$ & $51.442^{\circ} \mathrm{S}$ & $33.430^{\circ} \mathrm{W}$ & 1796 & 450 \\
\hline SA5D & $51.198^{\circ} \mathrm{S}$ & $34.084^{\circ} \mathrm{W}$ & 2677 & 820 \\
\hline SA $6 \mathrm{~A}$ & $51.043^{\circ} \mathrm{s}$ & $26.083^{\circ} \mathrm{W}$ & 3069 & 700 \\
\hline SA $6 B$ & $51.035^{\circ} \mathrm{S}$ & $26.108^{\circ} \mathrm{W}$ & 3092 & 550 \\
\hline SA $6 \mathrm{C}$ & $50.981^{\circ} \mathrm{S}$ & $26.247^{\circ} \mathrm{W}$ & 3098 & 450 \\
\hline SA6D & $51.042^{\circ} \mathrm{s}$ & $25.883^{\circ} \mathrm{W}$ & 3096 & 600 \\
\hline SA $6 E$ & $51.204^{\circ} \mathrm{s}$ & $26.075^{\circ} \mathrm{W}$ & 3131 & 750 \\
\hline SA 7A & $47.185^{\circ} \mathrm{S}$ & $04.420^{\circ} \mathrm{E}$ & 4778 & 800 \\
\hline SA 7B & $47.216^{\circ} \mathrm{S}$ & $04.864^{\circ} \mathrm{E}$ & 4624 & 700 \\
\hline SA $7 C$ & $47.234^{\circ} \mathrm{s}$ & $05.208^{\circ} \mathrm{E}$ & 4455 & 400 \\
\hline SA 7D & $47.503^{\circ} \mathrm{S}$ & $04.693^{\circ} \mathrm{E}$ & 4215 & 300 \\
\hline SA7E & $47.144^{\circ} \mathrm{S}$ & $05.692^{\circ} \mathrm{E}$ & 4413 & 510 \\
\hline
\end{tabular}


Table 1 (cont.)

\begin{tabular}{lllll} 
SITE & LATITUDE & LONGITUDE & $\begin{array}{l}\text { WATER } \\
\text { DEPTH }\end{array}(\mathrm{m})$ & $\begin{array}{l}\text { SEDIMENT } \\
\text { THICKNESS (m) }\end{array}$ \\
\hline SA8A & $47.134^{\circ} \mathrm{S}$ & $07.517^{\circ} \mathrm{E}$ & 2328 & 850 \\
SA8B & $47.079^{\circ} \mathrm{S}$ & $07.525^{\circ} \mathrm{E}$ & 2419 & 800 \\
SA8C & $46.992^{\circ} \mathrm{S}$ & $07.489^{\circ} \mathrm{E}$ & 2510 & 750 \\
SA8D & $47.157^{\circ} \mathrm{S}$ & $07.506^{\circ} \mathrm{E}$ & 2290 & 800 \\
SA8E & $46.91^{\circ} \mathrm{S}$ & $07.325^{\circ} \mathrm{E}$ & 2540 & $250-800$ \\
SA8F & $47.04^{\circ} \mathrm{S}$ & $08.018^{\circ} \mathrm{E}$ & 1700 & $250-800$ \\
SA8G & $46.948^{\circ} \mathrm{S}$ & $07.300^{\circ} \mathrm{E}$ & 2580 & $300-800$ \\
-
\end{tabular}


Table 2. Site Occupation Schedule

Ocean Drilling Program Leg 114

Site Location $\quad$ Transit Operations

4.3 days

SA2 ALT A $51.542^{\circ} \mathrm{S} \quad 30.623^{\circ} \mathrm{W}$

12.6 days $20 \mathrm{March}$

1.1 days

SA $3 A$

$$
51.987^{\circ} \mathrm{S} \quad 23.098^{\circ} \mathrm{W}
$$

10.9 days

4 April

5.0 days

SA 8C $\quad 46.992^{\circ} \mathrm{S} \quad 07.489^{\circ} \mathrm{E}$

12.8 days

21 April

12 days

Arrive Mauritius

14 May

59 days 


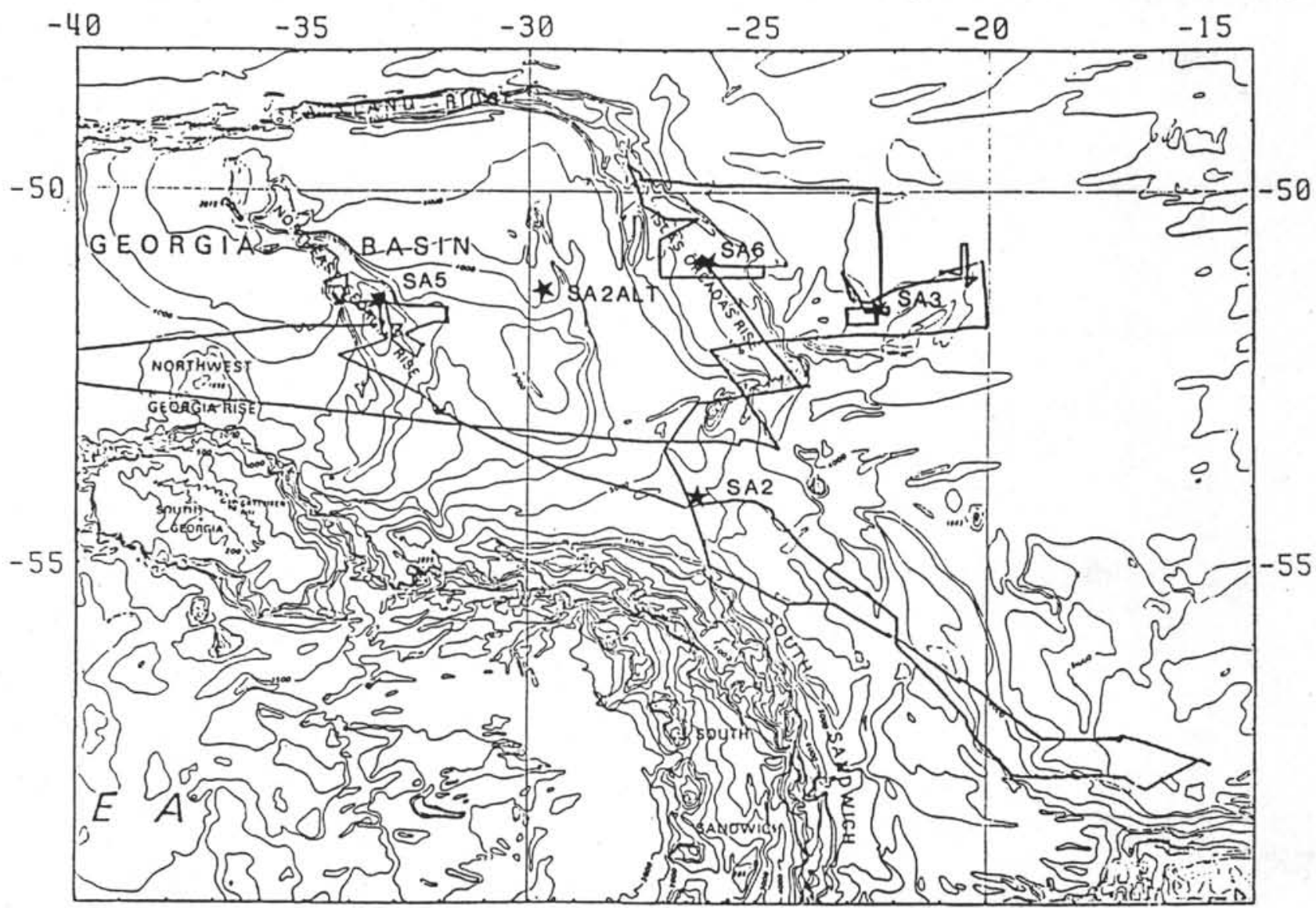

Ship's tracks for site survey of Sites SA5, $\mathrm{SA} 2, \mathrm{SA} 6$, and SA3. 


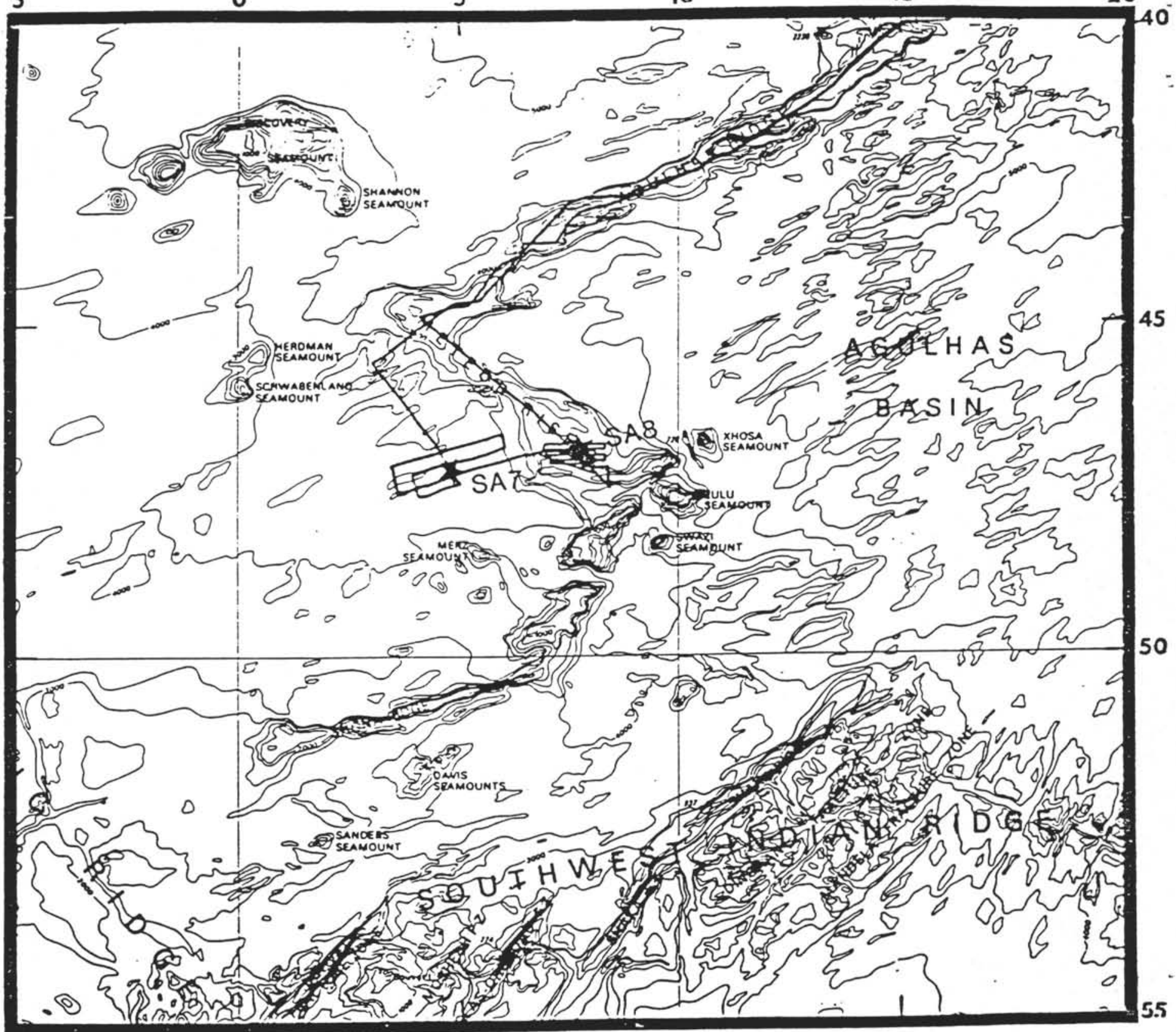

Ship's tracks for site survey of Sites SA7 and SA8. 
SITE NUMBER: SA2A (East of S. Sandwich Island Arc)

POSITION: $55.593^{\circ} \mathrm{S}, 22.101^{\circ} \mathrm{W}$ SEDIMENT THICKNESS: $600 \mathrm{~m}$

WATER DEPTH: $4275 \mathrm{~m} \quad$ PRIORITY: II

PROPOSED DRILLING PROGRAM: Double APC, XCB, approximate $650 \mathrm{~m}$ penetration.

SEISMIC RECORD: R/V Polar Duke, 2245Z, 9/8/86, profile R-S

LOGGING: Standard Schlumberger logs, 2 runs, seismic

stratigraphy tool and geochemical tool.

OBJECTIVES: Site SA2A lies on Upper Cretaceous (Maestrichtian) oceanic crust which predates the formation of the Islas Orcadas Rise and Meteor Rise and the deep water gateway which formed between these features. This site will provide a pre- to post-gateway record with which to interpret the influence of gateway formation on Southern Ocean and South Atlantic paleoceanography. Other objectives include documentation of: -Paleogene vertical water mass gradients (with shallower sites) -the evolution of the northern Weddell water mass, -development of the Antarctic Circumpolar Current (ACC), -the influence of the Drake Passage opening on the South Atlantic sector of the Southern Ocean, -temporal variations in Antarctic Bottom Water flow, -and a check on a basement age model. All proposed SA2 sites are the near conjugate locations of Leg 113 Site W5. Site W5 lies on the southern flank and Site SA2 on the northern flank of the America-Antarctica spreading center. This distribution of sites will, we hope, yield information on the effect of spreading center relief on the benthic paleoenvironment. Sites SA2A and SA2D are equivalent in basal age and sediment thickness. They are given a lower priority than $\mathrm{SA} 2 \mathrm{~B}$ and $\mathrm{SA} 2 \mathrm{C}$ because the basement age is nearly contemporaneous with the age of the Islas Orcadas and Meteor Rises.

SEDIMENT TYPE: Diatomaceous ooze, muddy diatomaceous ooze, calcareous/ siliceous ooze and chalk, zeolitic clay, and basalt. 
Page 28

SITE NUMBER: SA2B (East of S. Sandwich Island ArC)

POSITION: $54.873^{\circ} \mathrm{S}, 23.734^{\circ} \mathrm{W}$ SEDIMENT THICKNESS: $600 \mathrm{~m}$

WATER DEPTH: $3975 \mathrm{~m} \quad$ PRIORITY: II

PROPOSED DRILLING PROGRAM: Double APC, XCB, approximate $650 \mathrm{~m}$ penetration

SEISMIC RECORD: R/V Polar Duke, 0640Z, 9/9/86, profile R-S

LOGGING: Standard Schlumberger logs, 2 runs, seismic stratigraphy tool and geochemical tool.

OBJECTIVES: Site SA2B provides an optional thinner section than at SA2C with the loss of surficial sediments which are present at SA2C. The site lies on Upper Cretaceous (Campanian) oceanic crust which predates the formation of the Islas Orcadas Rise and Meteor Rise and the deep water gateway which formed between these features. This site will provide a pre- to post-gateway record with which to interpret the influence of gateway formation on Southern Ocean-South Atlantic paleoceanography. Other objectives include documentation of: -Paleogene vertical water mass gradients (with shallower sites -the evolution of the northern Weddell water mass, -development of the Antarctic Circumpolar Current (ACC), -the influence of the Drake Passage opening on the South Atlantic sector of the Southern Ocean, -temporal variations in Antarctic Bottom Water flow, -and a check on a basement age model.

All proposed $S A 2$ sites are the near conjugate locations of Leg 113 Site W5. Site W5 lies on the southern flank and Site SA2 on the northern flank of the America-Antarctica spreading center. This distribution of sites will, we hope, yield information on the effect of spreading center relief on the benthic paleoenvironment. Sites SA2A and SA2D are equivalent in basal age and sediment thickness. They are given a lower priority than $\mathrm{SA} 2 \mathrm{~B}$ and $\mathrm{SA} 2 \mathrm{C}$ because the basement age is nearly contemporaneous with the age of the Islas Orcadas and Meteor Rises.

SEDIMENT TYPE: Diatomaceous ooze, muddy diatomaceous ooze, calcareous/ siliceous ooze and chalk, zeolitic clay (Eocene), and basalt. 
Page 29

SITE NUMBER: SA2C (East of $S$. Sandwich Island Arc)

POSITION: $55.463^{\circ} \mathrm{S}, 23.450^{\circ} \mathrm{W}$ SEDIMENT THICKNESS: $600 \mathrm{~m}$

WATER DEPTH: $3975 \mathrm{~m} \quad$ PRIORITY: II

PROPOSED DRILLING PROGRAM: Double APC, XCB, approximate $650 \mathrm{~m}$ penetration.

SEISMIC RECORD: R/V Polar Duke, 1050Z, 9/5/86, profile U-T

LOGGING: Standard Schlumberger logs, 2 runs, seismic stratigraphy tool and geochemical tool.

OBJECTIVES: Site SA2C provides a thicker section than at SA2B with the addition of surficial sediments which are eroded at SA2B. The site lies on Upper Cretaceous (Campanian) oceanic crust which predates the formation of the Islas Orcadas Rise and Meteor Rise and the deep water gateway which formed between these features. This site will provide a pre- to post-gateway record with which to interpret the influence of gateway formation on Southern Ocean-South Atlantic paleoceanography. Other objectives include documentation of:

-Paleogene vertical water mass gradients (with shallower sites -the evolution of the northern Weddell water mass, -development of the Antarctic Circumpolar Current (ACC), -the influence of the Drake Passage opening on the South Atlantic sector of the Southern Ocean, -temporal variations in Antarctic Bottom Water flow, -and a check on a basement age model.

A11 proposed SA2 sites are the near conjugate locations of Leg 113 Site W5. Site W5 lies on the southern flank and Site SA2 on the northern flank of the America-Antarctica spreading center. This distribution of sites wili, we hope, yield information on the effect of spreading center relief on the benthic paleoenvironment. Sites SA2A and SA2D are equivalent in basal age and sediment thickness. They are given a lower priority than $S A 2 B$ and $S A 2 C$ because the basement age is nearly contemporaneous with the age of the Islas Orcadas and Meteor Rises.

SEDIMENT TYPE: Diatomaceous ooze, muddy diatomaceous ooze, calcareous/ siliceous ooze and chalk, zeolitic clay (Eocene), and basalt. 
Page 30

SITE NUMBER: SA2D (East of S. Sandwich Island Arc)

POSITION: $55.852^{\circ} \mathrm{S}, 22.103^{\circ} \mathrm{W} \quad$ SEDIMENT THICKNESS: $600 \mathrm{~m}$

WATER DEPTH: $4350 \mathrm{~m} \quad$ PRIORITY: II

PROPOSED DRILLING PROGRAM: Double APC, XCB, approximate $650 \mathrm{~m}$

penetration

SEISMIC RECORD: R/V Polar Duke, 1750Z, 9/5/86, profile U-T

LOGGING: Standard Schlumberger logs, 2 runs, seismic

stratigraphy tool and geochemical tool.

OBJECTIVES: Site SA2D lies on Upper Cretaceous (Maestrichtian) oceanic crust that predates the formation of the Islas Orcadas Rise and Meteor Rise and the deep water gateway which formed between these Eeatures. This site will provide a pre- to post-gateway record with which to interpret the influence of gateway formation on Southern Ocean-South Atlantic

paleoceanography. Other objectives include documentation of: -Paleogene vertical water mass gradients (with shallower sites -the evolution of the northern Weddell water mass, -development of the Antarctic Circumpolar Current (ACC), -the influence of the Drake Passage opening on the South Atlantic sector of the Southern Ocean, -temporal variations in Antarctic Bottom Water flow, -and a check on a basement age model.

All proposed SA2 sites are the near conjugate locations of Leg 113 Site W5. Site w5 lies on the southern flank and Site SA 2 on the northern flank of the America-Antarctica spreading center. This distribution of sites will, we hope, yield information on the effect of spreading center relief on the benthic paleoenvironment. Sites SA2A and SA2D are equivalent in basal age and sediment thickness. They are given a lower priority than $\mathrm{SA} 2 \mathrm{~B}$ and $\mathrm{SA} 2 \mathrm{C}$ because the basement age is nearly contemporaneous with the age of the Islas Orcadas and Meteor Rises.

SEDIMENT TYPE: Diatomaceous ooze, muddy diatomaceous ooze, calcareous/ siliceous ooze and chalk, zeolitic clay (Eocene), and basalt. 


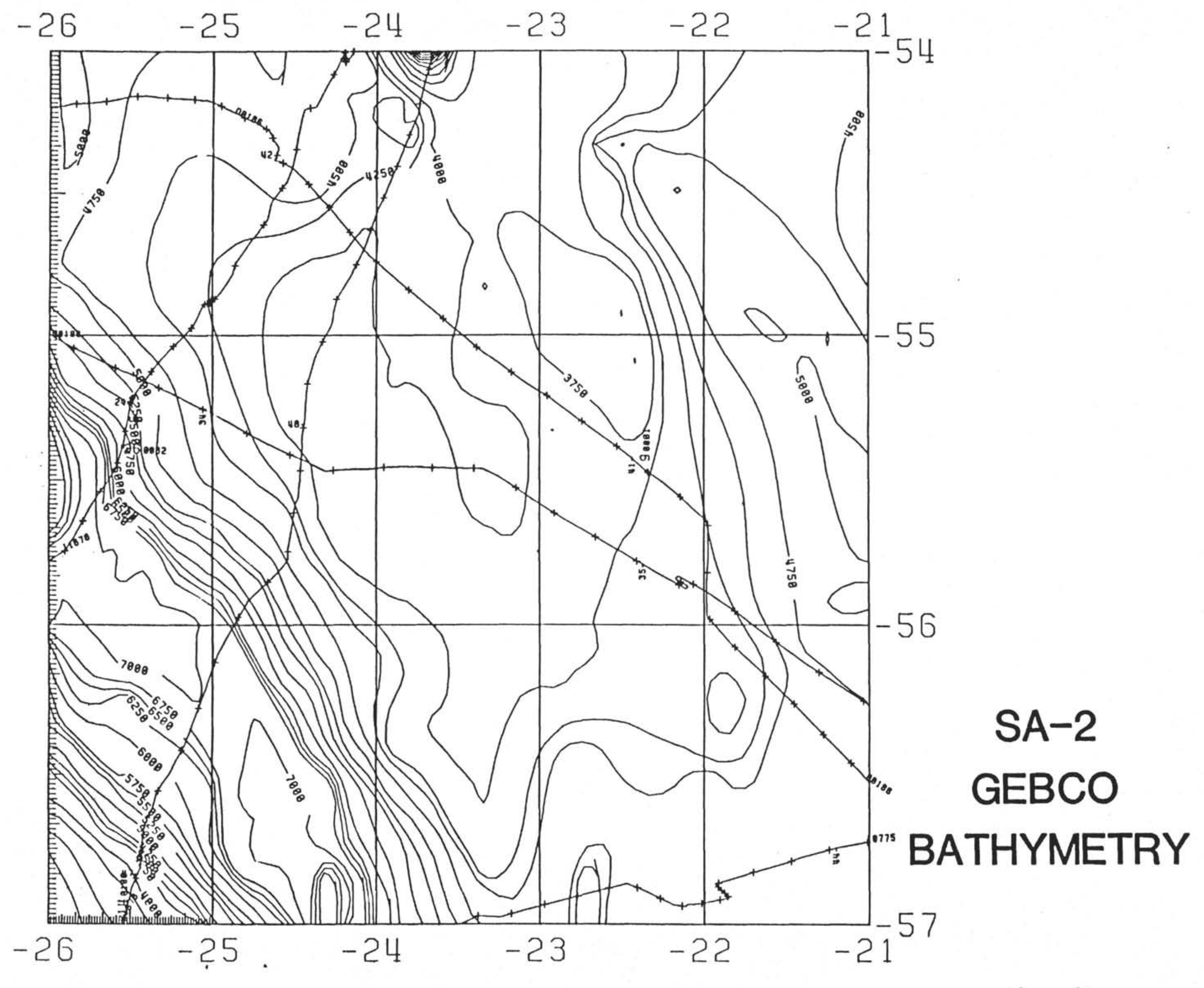




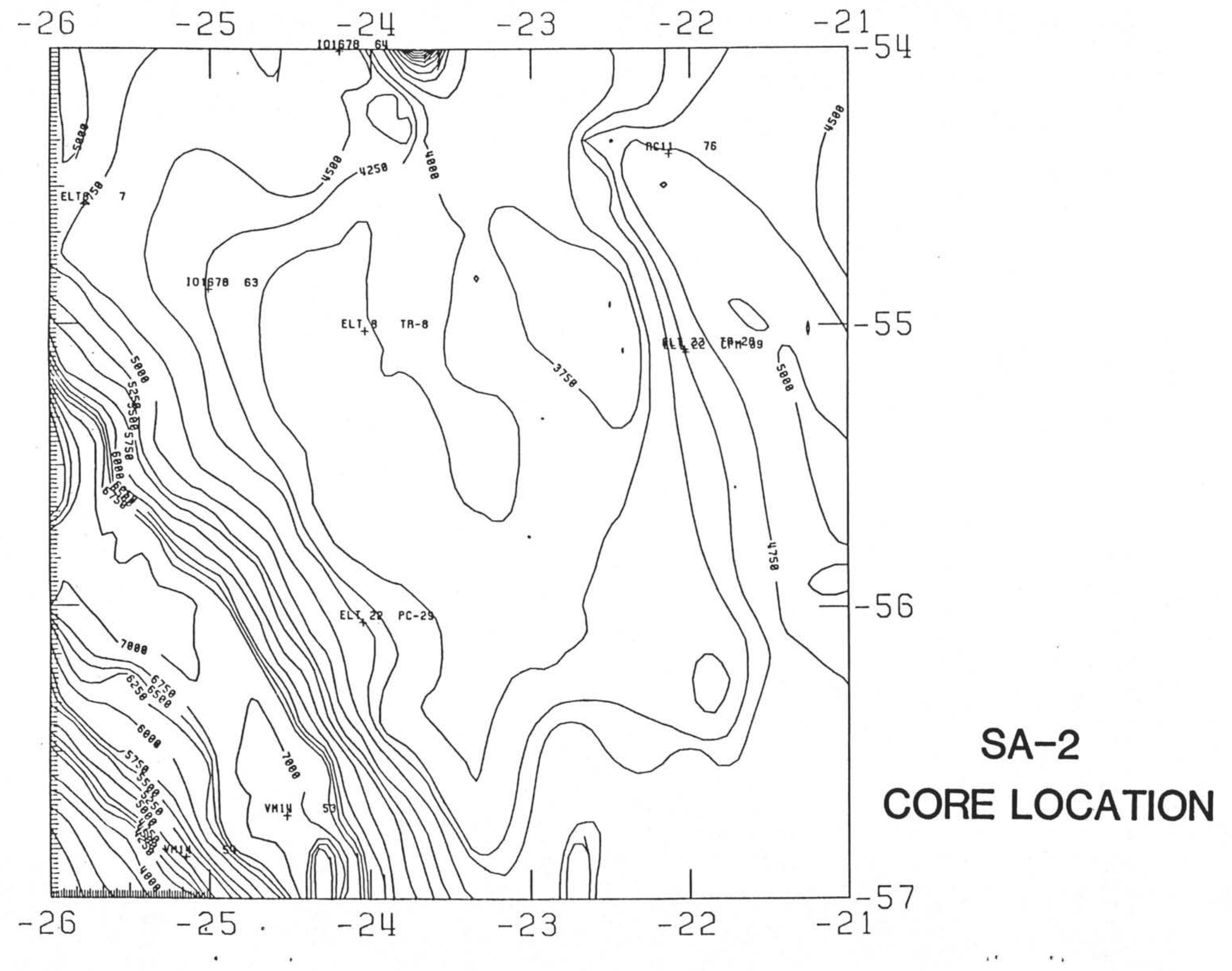




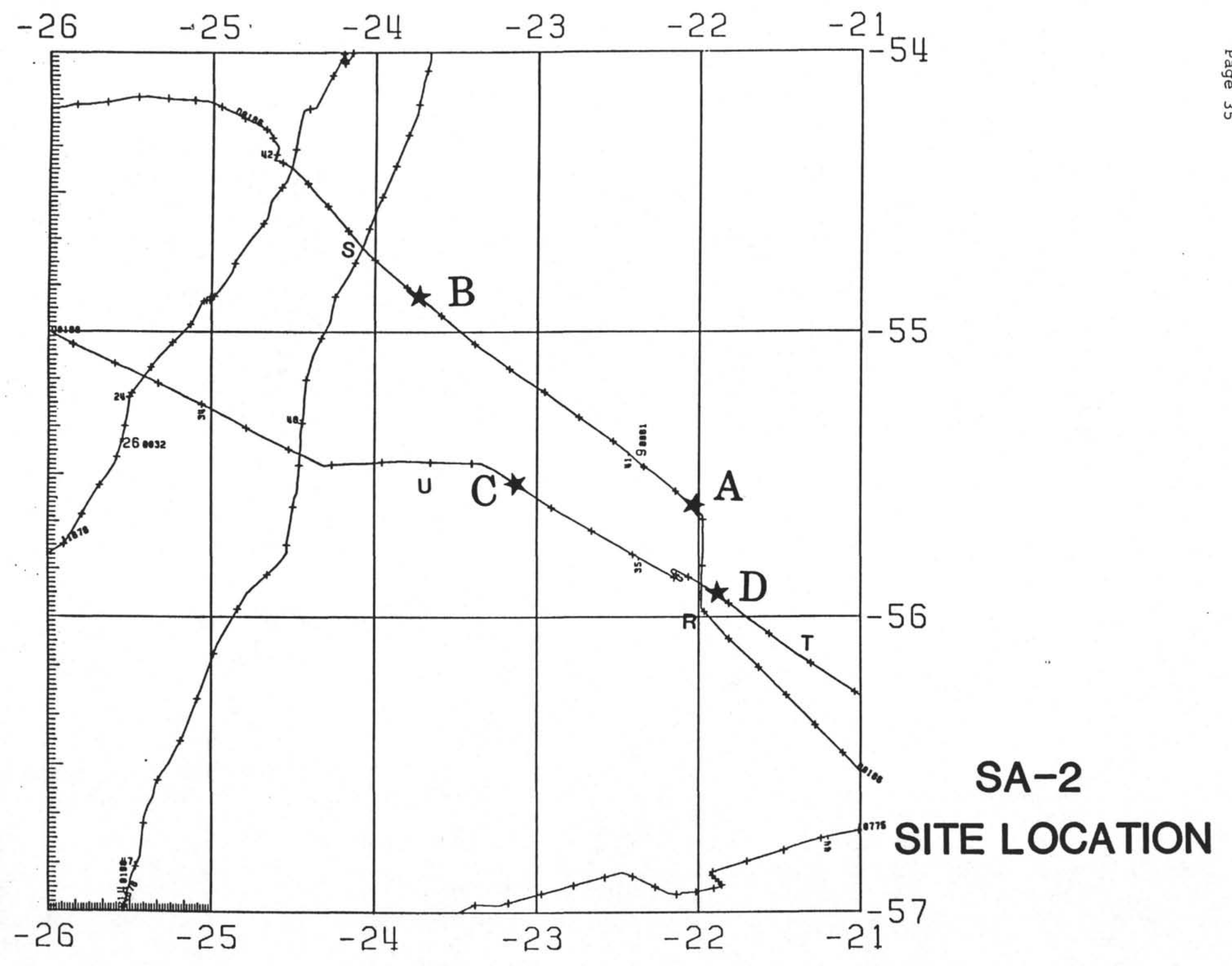




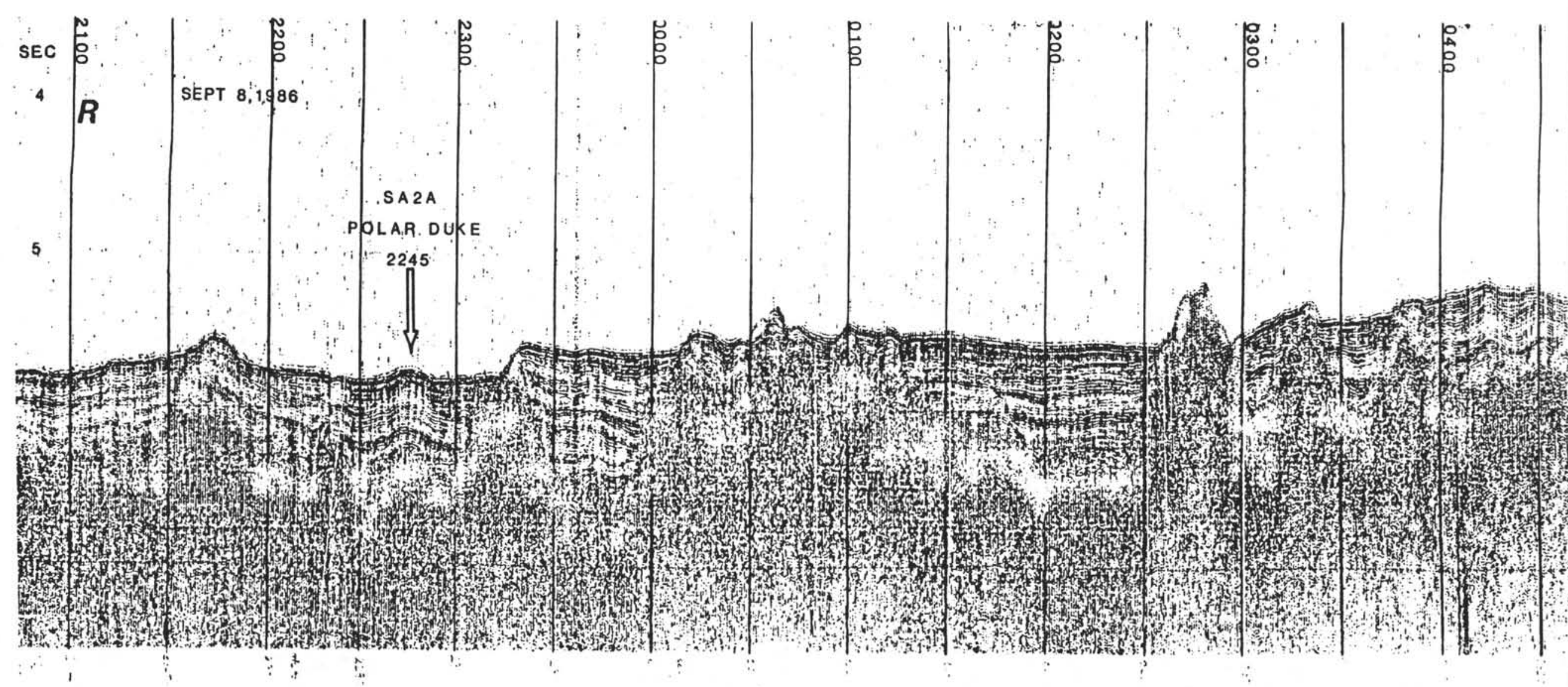




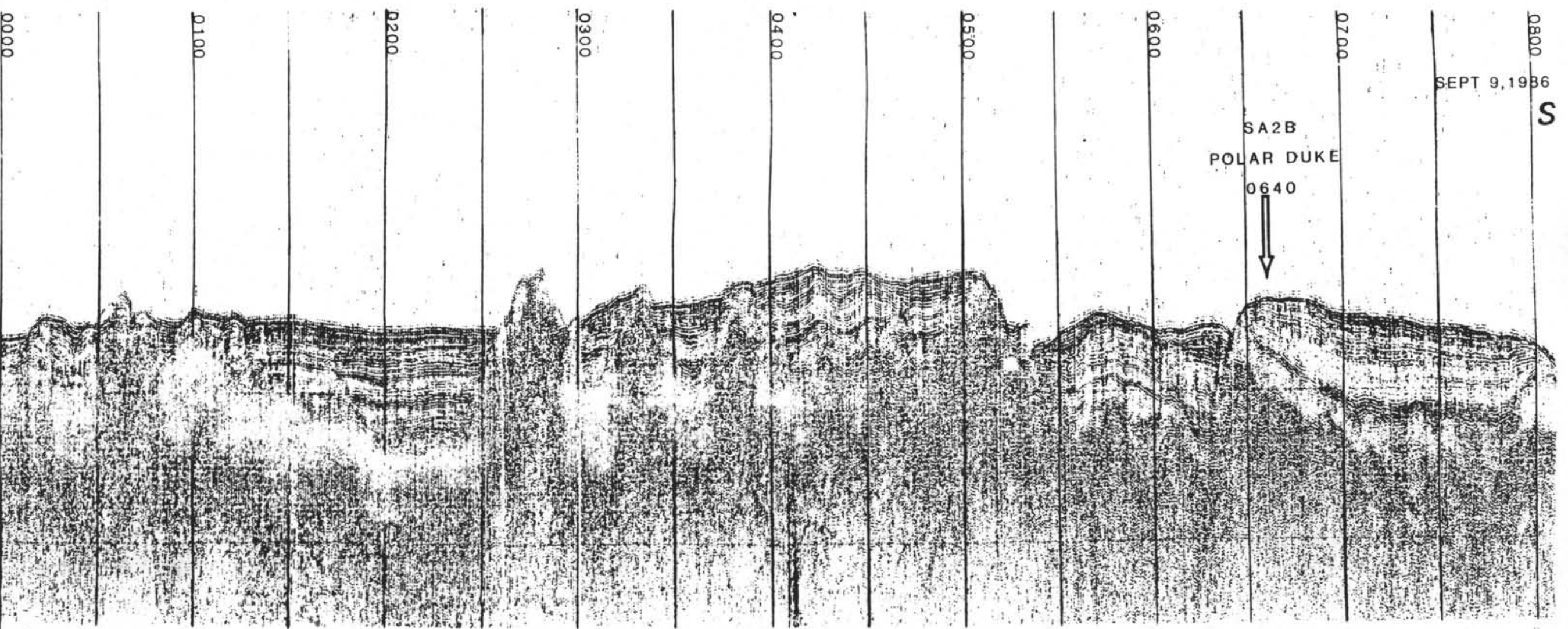




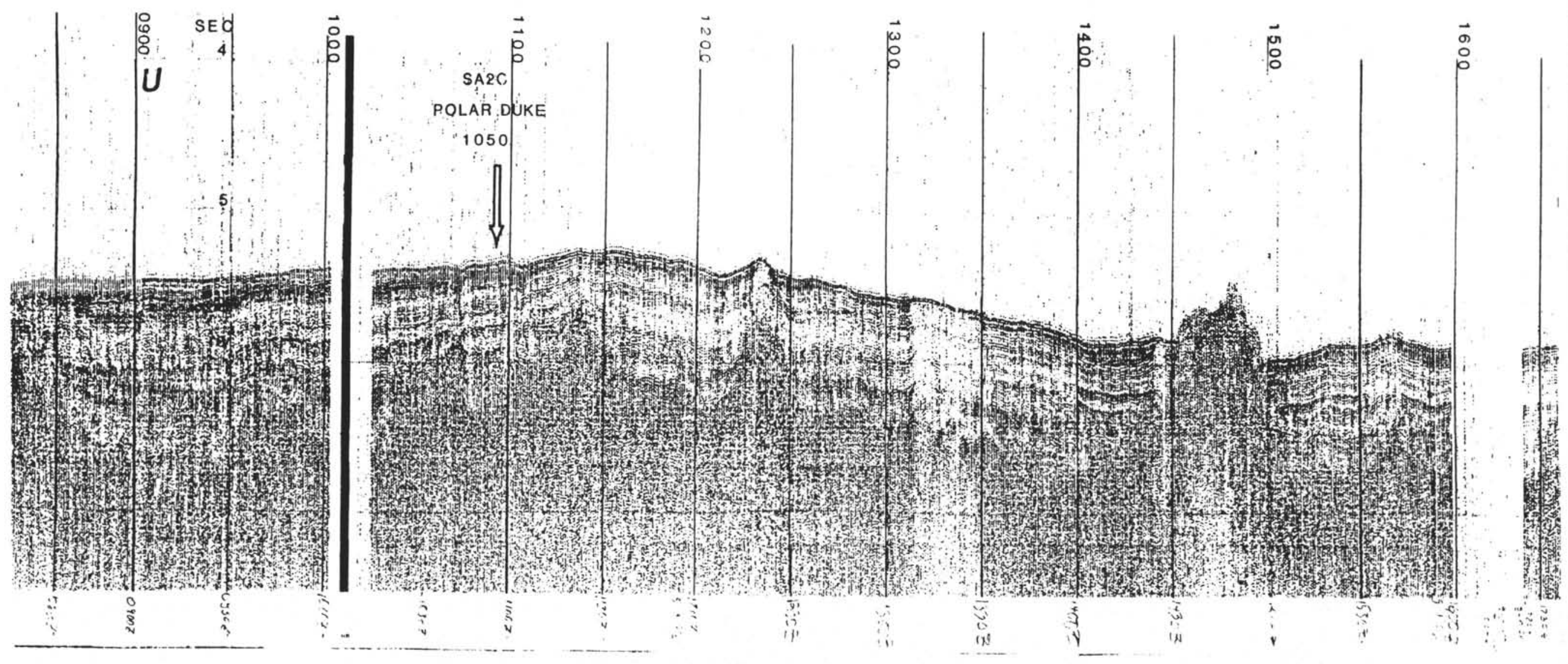




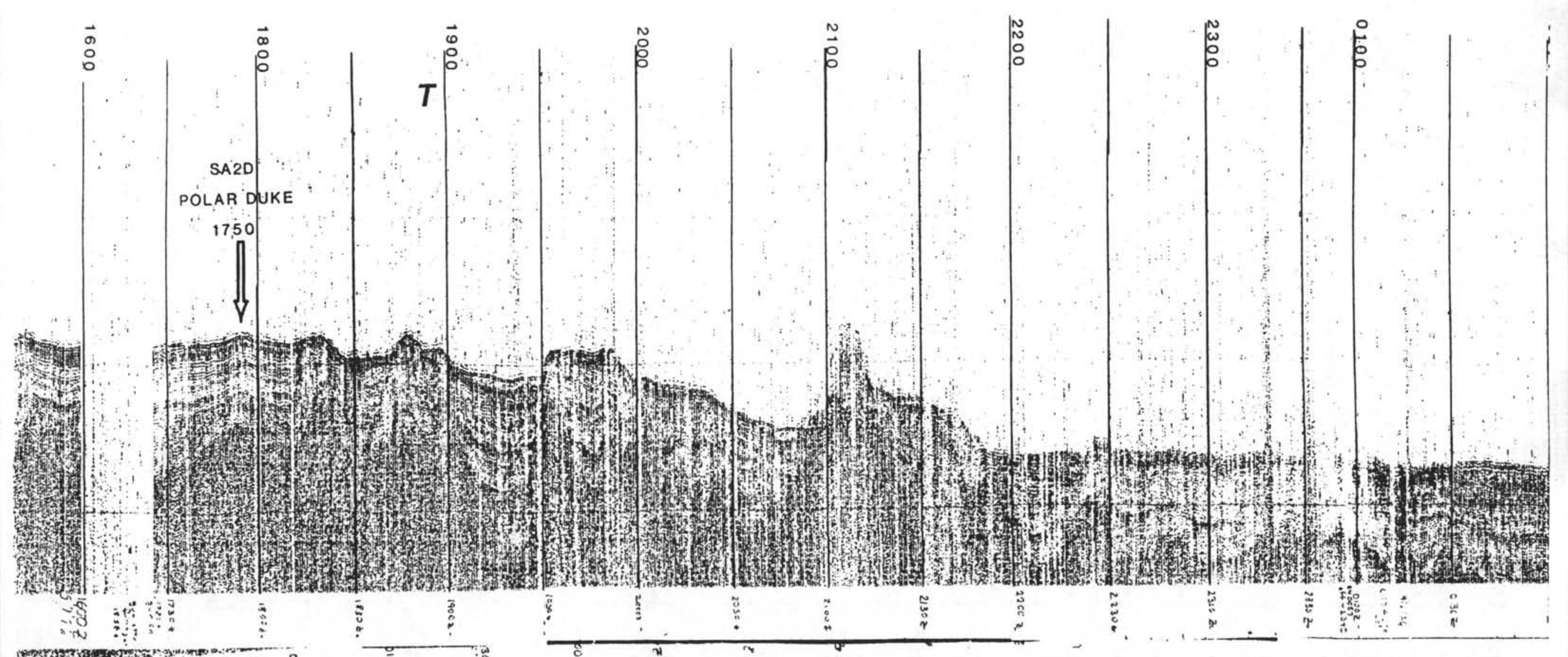




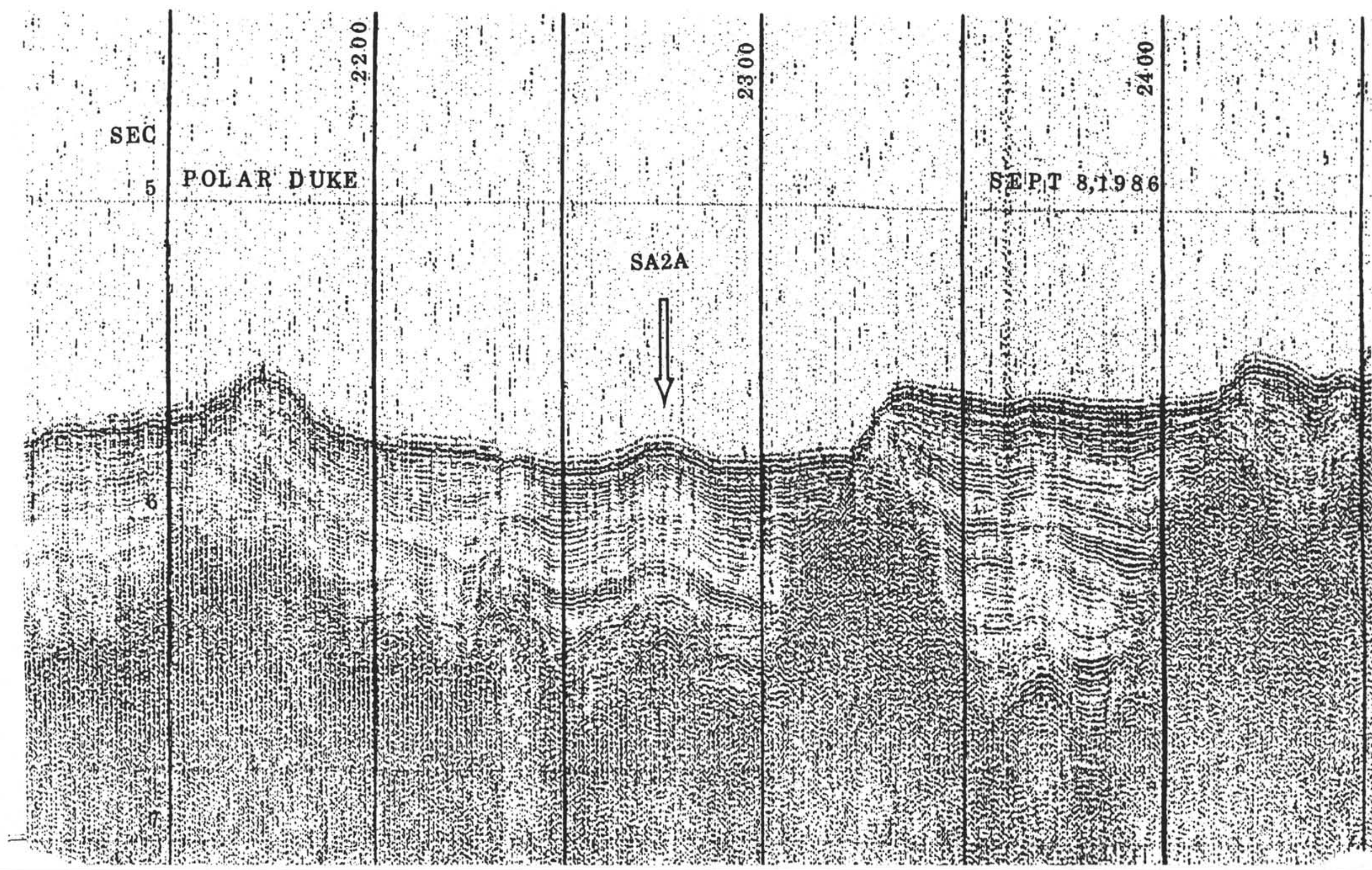




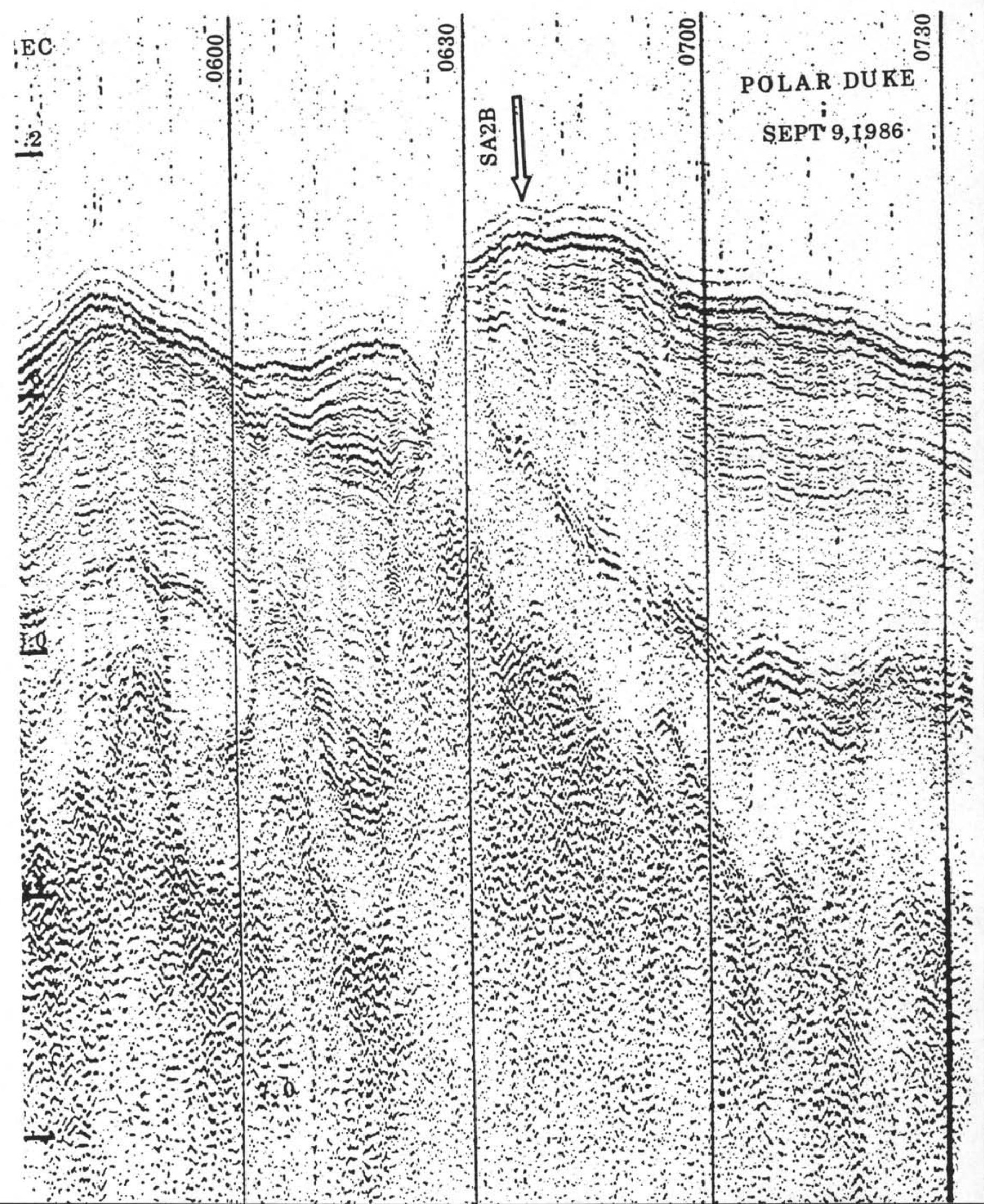




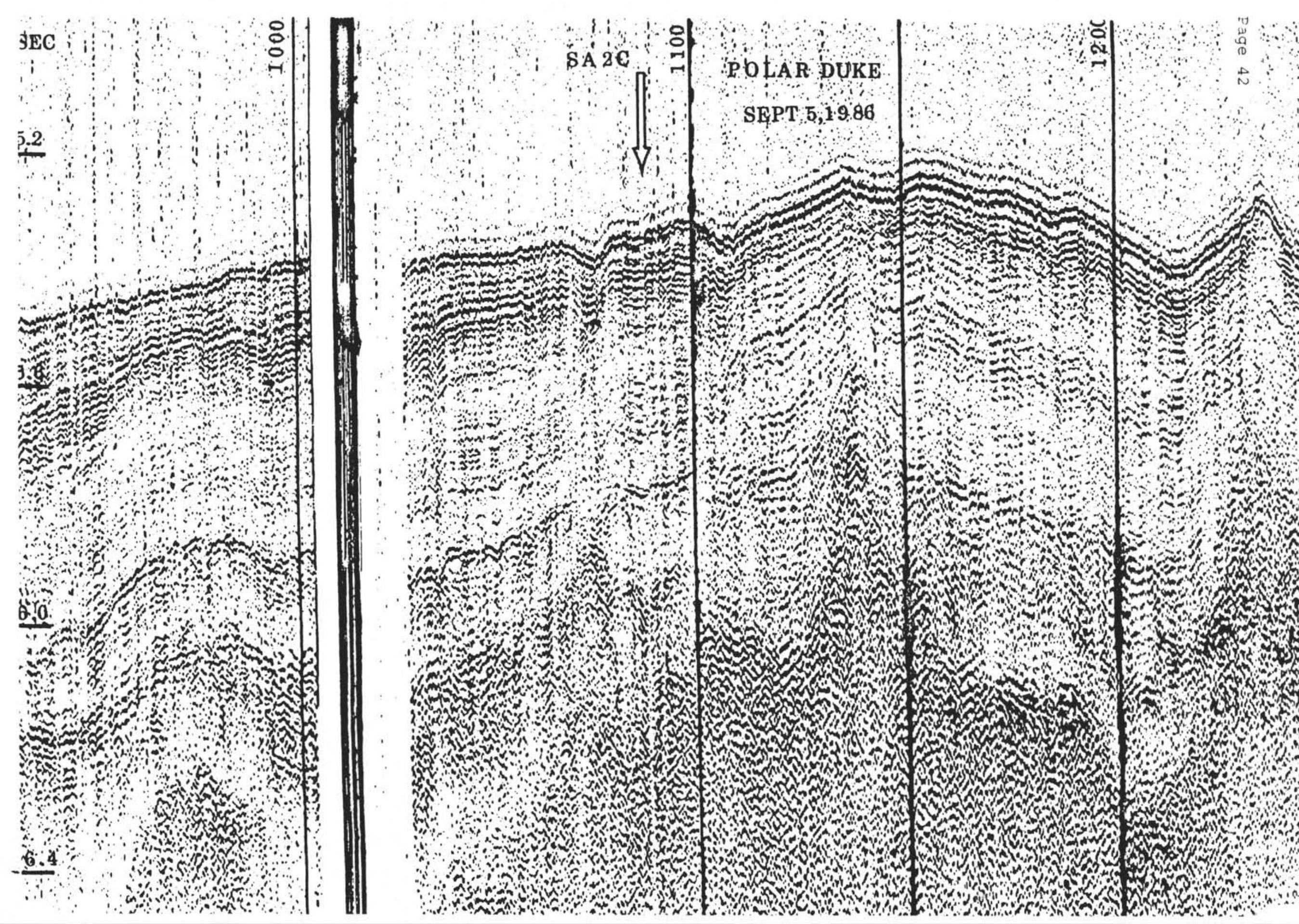




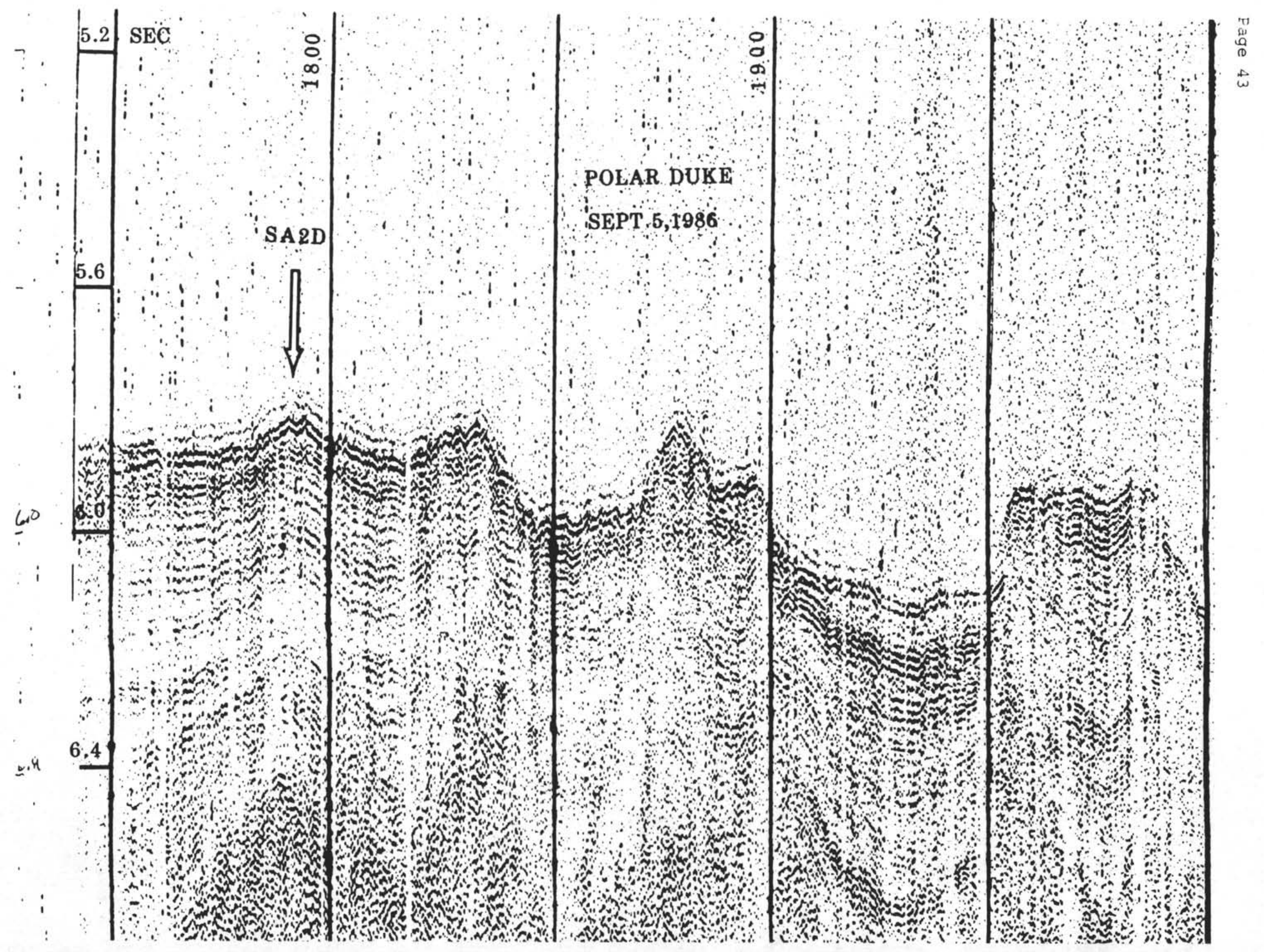


SITE NUMBER: SA2 ALT A (West of the Islas Orcadas Rise)

POSITION: $51.542^{\circ} \mathrm{S}, 30.623^{\circ} \mathrm{W}$ SEDIMENT THICKNESS: $700 \mathrm{~m}$

WATER DEPTH: $3750 \mathrm{~m} \quad$ PRIORITY: I

PROPOSED DRILLING PROGRAM: Double APC, XCB, approximate $750 \mathrm{~m}$

penetration.

SEISMIC RECORD: ARA Islas Orcadas 0775 Nov 24,1975 04200

LOGGING: Standard Schlumberger logs, 2 runs, seismic

stratigraphy tool and geochemical tool.

OBJECTIVES: Sites SA2 ALT A and SA2 ALT B provide alternate sites to the proposed $S A 2(A-D)$ in the event that we are not allowed to drill within the South Sandwich EEZ. The sites lie on the .. Upper-Mid Cretaceous oceanic crust that predates the formation of the Islas Orcadas Rise and Meteor Rise and the deep water gateway which formed between these features. Site SA2 ALT B has an exposed basal section of likely Eocene to Paleocene age. Site SA2 ALT B will therefore provide a pre-gateway to syn-gateway record with minimum drilling time. Site SA2 ALT A should provide Neogene sediments as well. Site SA2 ALT A will provide a pre- to post-gateway record with which to interpret the influence of gateway formation on Southern Ocean-South Atlantic paleoceanography. Other objectives include documentation of:

-development of the Antarctic Circumpolar Current (ACC), -the influence of the Drake Passage opening on the South Atlantic sector of the Southern Ocean, -temporal variations in Antarctic Bottom Water flow, -and a check on basement age model.

SEDIMENT TYPE: Diatomaceous ooze, muddy diatomaceous ooze, calcareous/ siliceous ooze and chalk, zeolitic clay (Eocene), and basalt. 
SITE NUMBER: SA2 ALT B (West of the Islas Orcadas Rise)

POSITION: $51.538^{\circ} \mathrm{S}, 30.309^{\circ} \mathrm{W}$ SEDIMENT THICKNESS: $350 \mathrm{~m}$

WATER DEPTH: $3600 \mathrm{~m} \quad$ PRIORITY: II PROPOSED DRILLING PROGRAM: $\begin{aligned} & \text { Double APC, XCB, approximate } 400 \mathrm{~m} \\ & \text { penetration. }\end{aligned}$

SEISMIC RECORD: ARA Islas Orcadas 0775 Nov 24,1975 0250

LOGGING: Standard Schlumberger logs, 2 runs, seismic

stratigraphy tool and geochemical tool.

OBJECTIVES: Sites SA2 ALT A and SA2 ALT B provide alternate sites to the proposed Site SA2(A-D) in the event that we are not allowed to arill within the South Sandwich EEZ. The sites lie on the Upper-Mid Cretaceous oceanic crust that pre-dates the formation of the Islas Orcadas Rise and Meteor Rise and the deep water gateway which formed between these features. Site SA2 ALT B has an exposed basal section of likely Eocene to Paleocene age. Site SA2 ALT B will therefore provide a pregateway to syn-gateway record with minimum drilling time. Site SA2 ALT A should provide Neogene sediments as well. Site SA2 ALT A will provide a pre- to post-gateway record with which to interpret the influence of gateway formation on Southern Ocean-South Atlantic paleoceanography. Other objectives include documentation of: -development of the Antarctic Circumpolar Current (ACC), -the influence of the Drake Passage opening on the South Atlantic sector of the Southern Ocean, -temporal variations in Antarctic Bottom Water flow, -and a check on basement age model.

SEDIMENT TYPE: Diatomaceous ooze, muddy diatomaceous ooze, calcareous/ siliceous ooze and chalk, zeolitic clay (Eocene), and basalt. 


\section{SA-2 ALT. SITE LOCATION}

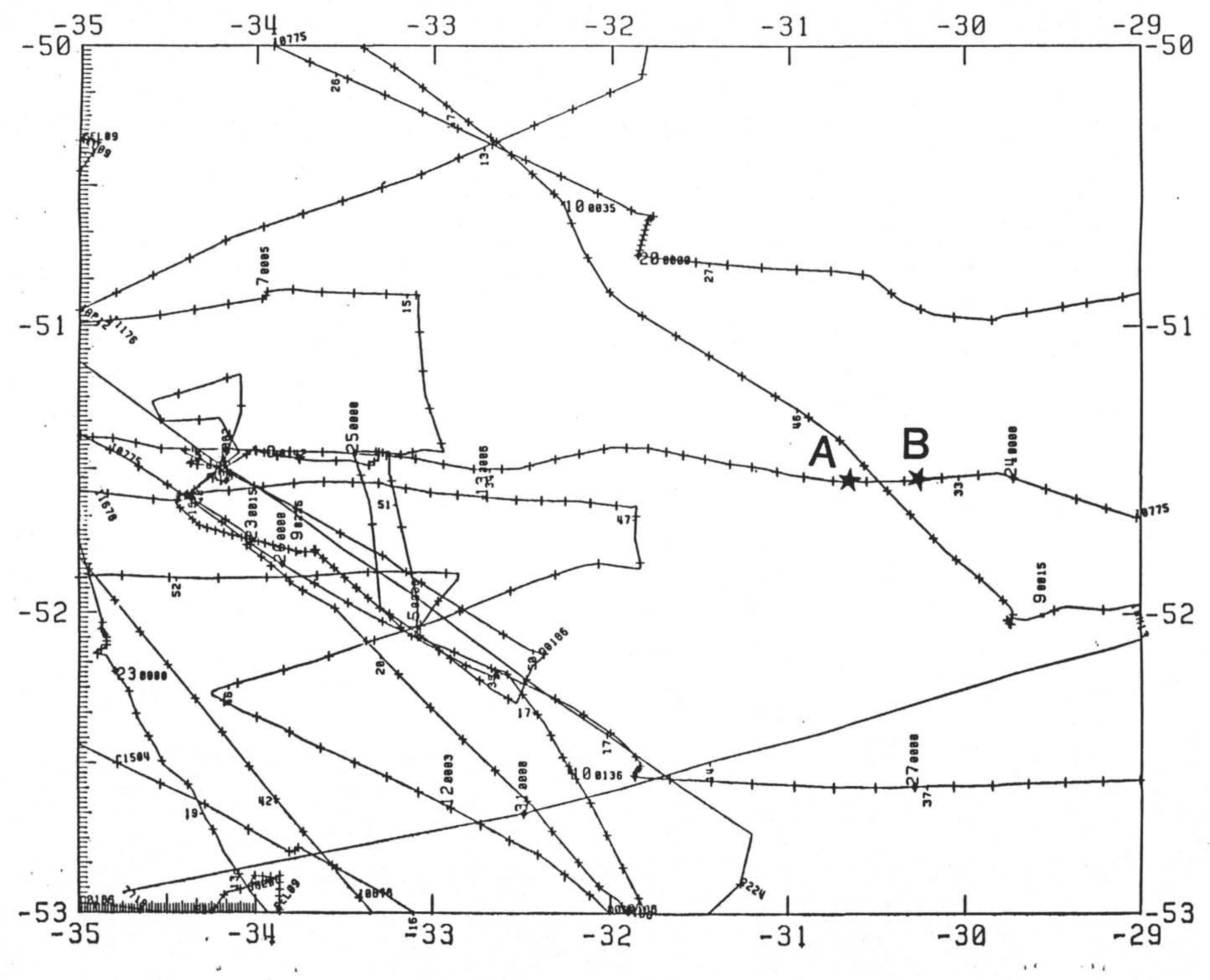


SITE NUMBER: SA3A (East of the Islas Orcadas Rise)

POSITION: $51.987^{\circ} \mathrm{S}, 23.098^{\circ} \mathrm{W}$ SEDIMENT THICKNESS: $600 \mathrm{~m}$

WATER DEPTH: $4505 \mathrm{~m} \quad$ PRIORITY: I

PROPOSED DRILLING PROGRAM: Double APC, XCB, approximate $650 \mathrm{~m}$ penetration.

SEISMIC RECORD: R/V Polar Duke, 1227Z, 8/27/86

LOGGING: Standard Schlumberger logs, 2 runs, seismic stratigraphy tool and geochemical tool.

OBJECTIVES: Site SA3 lies east of the Islas Orcadas Rise on oceanic crust of mid-Eocene age (Chron C21.8R) created by the mid-Atlantic Ridge which separated the Islas Orcadas Rise and Meteor Rise in the early Paleocene. The major objective at this site is to obtain a sedimentary record of the oceanic gateway between the South Atlantic and Weddell Basin. In conjunction with Site SA2, Site SA3 will provide a history of deep water circulation through the gateway as a result of its growth and the subsidence of surrounding relief. A comparison of Sites SA 3 and SA7 will provide information on meridional environmental development. With Sites SA5, SA6, and SA8 the paleoenvironmental depth dependence can also be investigated. Other objectives at this site include evaluation of:

-the vertical water mass gradients during the Paleogene (with shallow sites), -development of the ACC, -migration history of the Polar Front, -temporal variations in AABW flow.

Sites SA3 (A-D) provide various options in sampling sediments which appear between two seismically apparent unconformities. A preliminary interpretation is that the lower unconformity is a middle to late Eocene erosional event associated with the gateway opening. The upper unconformity is probably Miocene in age and likely is associated with the Drake Passage opening • Three sequences appear:

-a seismically transparent lower sequence

-a seismically striated middle sequence

-an upper striated sequence.

SEDIMENT TYPE: Diatomaceous ooze, calcareous/siliceous ooze and chalk, zeolitic clay (Eocene), basalt. 
Page 49

SITE NUMBER: SA3B (East of the Islas Orcadas Rise)

POSITION: $51.623^{\circ} \mathrm{S}, 23.387^{\circ} \mathrm{W}$ SEDIMENT THICKNESS: $600 \mathrm{~m}$

WATER DEPTH: $4506 \mathrm{~m}$ PRIORITY: II

PROPOSED DRILLING PROGRAM: Double APC, XCB, approximate $650 \mathrm{~m}$ penetration.

SEISMIC RECORD: R/V Polar Duke, 0130Z, 8/30/86, profile Q-R

LOGGING: Standard Schlumberger logs, 2 runs, seismic

stratigraphy tool and geochemical tool.

OBJECTIVES: Site SA3B lies east of the Islas Orcadas Rise on oceanic crust of mid-Eocene age (Chron C21.ON) created by the mid-Atlantic Ridge which separated the Islas Orcadas Rise and Meteor Rise in the early Paleocene. The major objective at this site is to obtain a sedimentary record of the oceanic gateway between the South Atlantic and Weddell Basin. In conjunction with Site SA2, Site SA 3 will provide a history of deep water circulation through the gateway as a result of its growth and the subsidence of surrounding relief. A comparison of Sites SA3 and SA7 will provide information on meridional environmental development. With Sites SA5, SA6, and SA8 the paleoenvironmental depth dependence can also be investigated. Other objectives at this site include evaluation of: -the vertical water mass gradients during the Paleogene (with shallow sites), -development of the ACC, -migration history of the Polar Front, -temporal variations in AAB' flow. Sites SA3 (A-D) provide various options in sampling sediments which appear between two seismically apparent unconformities. A preliminary interpretation is that the lower unconformity is a midale to late Eocene erosional event associated with the gateway opening. The upper unconformity is probably Miocene in age and likely is associated with the Drake Passage opening. Three sequences appear:

-a seismically transparent lower sequence -a seismically striated middle sequence -an upper striated sequence.

SEDIMENT TYPE: Diatomaceous ooze, calcareous/siliceous ooze and chalk, zeolitic clay (Eocene), basalt. 
Page 50

SITE NUMBER: SA3C (East of the Islas Orcadas Rise)

POSITION: $51.626^{\circ} \mathrm{S}, 23.013^{\circ} \mathrm{W}$ SEDIMENT THICKNESS: $600 \mathrm{~m}$

WATER DEPTH: $4543 \mathrm{~m} \quad$ PRIORITY: II

PROPOSED DRILLING PROGRAM: Double APC, XCB, approximate $650 \mathrm{~m}$ penetration.

SEISMIC RECORD: R/V Polar Duke, 0400Z, 8/30/86, profile Q-R

LOGGING: Standard Schlumberger logs, 2 runs, seismic

stratigraphy tool and geochemical tool.

OBJECTIVES: Site SA3C lies east of the Islas Orcadas Rise on oceanic crust of mid-Eocene age (Chron C22. ON) created by the mid-Atlantic Ridge which separated the Islas Orcadas Rise and Meteor Rise in the early Paleocene. The major objective at this site is to obtain a sedimentary record of the oceanic gateway between the South Atlantic and Weddell Basin. In conjunction with Site SA2, Site SA3 will provide a history of deep water circulation through the gateway as a result of its growth and the subsidence of surrounding relief. A comparison of Sites SA 3 and SA7 will provide information on meridional environmental development. With Sites SA5, SA6, and SA8 the paleoenvironmental depth dependence can also be investigated. Other objectives at this site include evaluation of:

-the vertical water mass gradients during the Paleogene (with shallow sites), -development of the ACC, -migration history of the Polar Front, -temporal variations in AABW flow.

Sites SA3 (A-D) provide various options in sampling sediments which appear between two seismically apparent unconformities. A preliminary interpretation is that the lower unconformity is a middle to late Eocene erosional event associated with the gateway opening. The upper unconformity is probably Miocene in age and likely is associated with the Drake Passage opening. Three sequences appear:

-a seismically transparent lower sequence

-a seismically striated middle sequence

-an upper striated sequence.

SEDIMENT TYPE: Diatomaceous ooze, calcareous/siliceous ooze and chalk, zeolitic clay (Eocene), basalt. 
Page 51

SITE NUMBER: SA3D (East of the Islas Orcadas Rise)

POSITION: $51.838^{\circ} \mathrm{S}, 22.476^{\circ} \mathrm{W}$ SEDIMENT THICKNESS: $250 \mathrm{~m}$

WATER DEPTH: $4535 \mathrm{~m} \quad$ PRIORITY: II

PROPOSED DRILLING PROGRAM: Double APC, XCB, approximate $300 \mathrm{~m}$

penetration.

SEISMIC RECORD: R/V Polar Duke, 0800Z, 8/30/86, profile Q-R

LOGGING: Standard Schlumberger logs, 2 runs, seismic

stratigraphy tool and geochemical tool.

OBJECTIVES: Site SA3D lies east of the Islas Orcadas Rise on oceanic crust of mid-Eocene age (Chron C21. ON) created by the mid-Atlantic Ridge which separated the Islas Orcadas Rise and Meteor Rise in the early Paleocene. The major objective at this site is to obtain a sedimentary record of the oceanic gateway between the South Atlantic and Weddell Basin. In conjunction with Site SA2, Site SA3 will provide a history of deep water circulation through the gateway as a result of its growth and the subsidence of surrounding relief. A comparison of Sites SA3 and SA7 will provide information on meridional environmental development. With Sites SA5, SA6, and SA8 the paleoenvironmental depth dependence can also be investigated. Other objectives at this site include evaluation of: -the vertical water mass gradients during the Paleogene (with shallow sites), -development of the ACC, -migration history of the Polar Front, -temporal variations in AABW flow. Sites SA3 (A-D) provide various options in sampling sediments which appear between two seismically apparent unconformities. A preliminary interpretation is that the lower unconformity is a middle to late Eocene erosional event associated with the gateway opening. The upper unconformity is probably Miocene in age and likely is associated with the Drake Passage opening. Three sequences appear:

-a seismically transparent lower sequence

-a seismically striated middle sequence

-an upper striated sequence.

SEDIMENT TYPE: Diatomaceous ooze, calcareous/siliceous ooze and chalk, zeolitic clay (Eocene), basalt. 


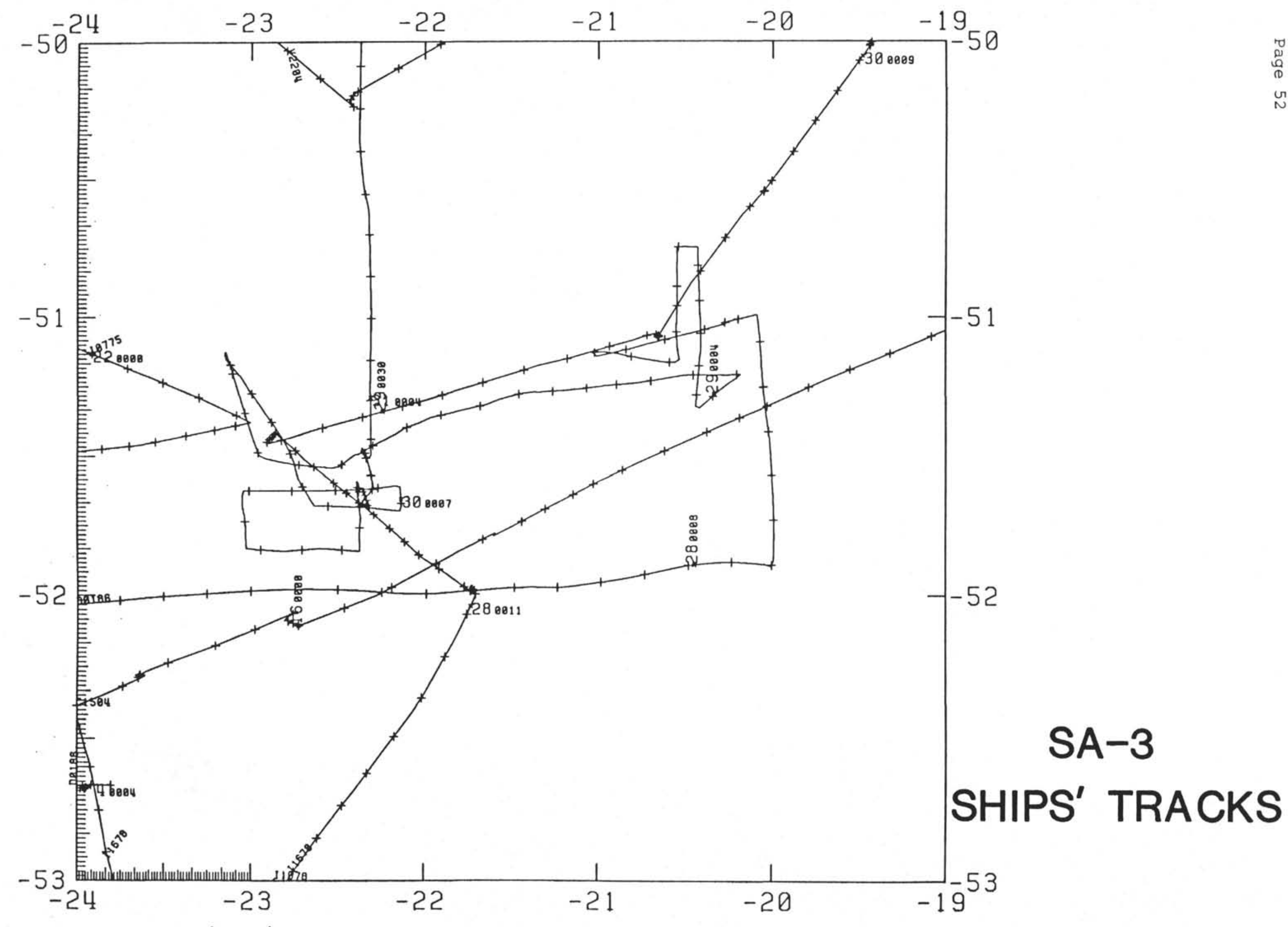




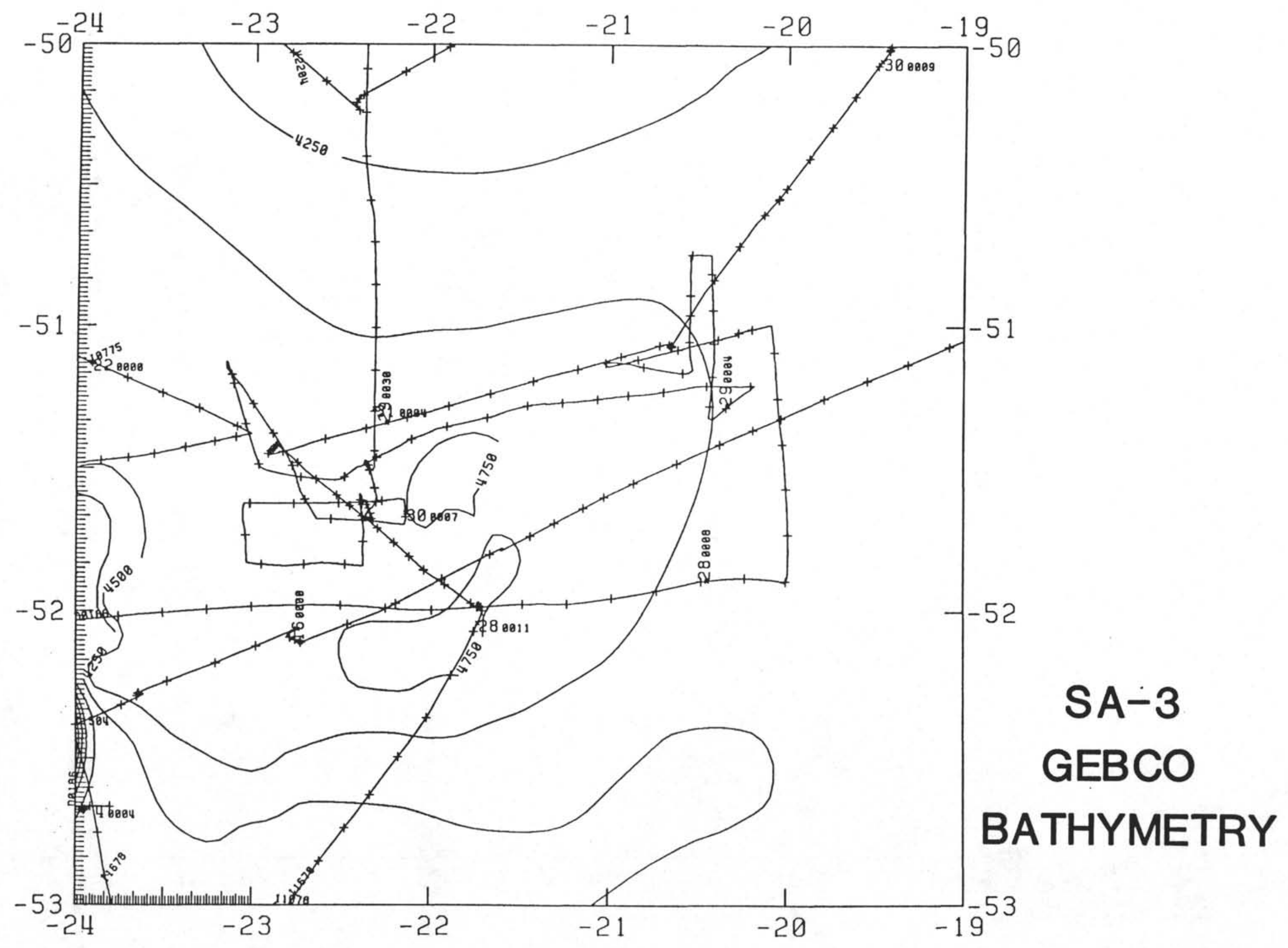




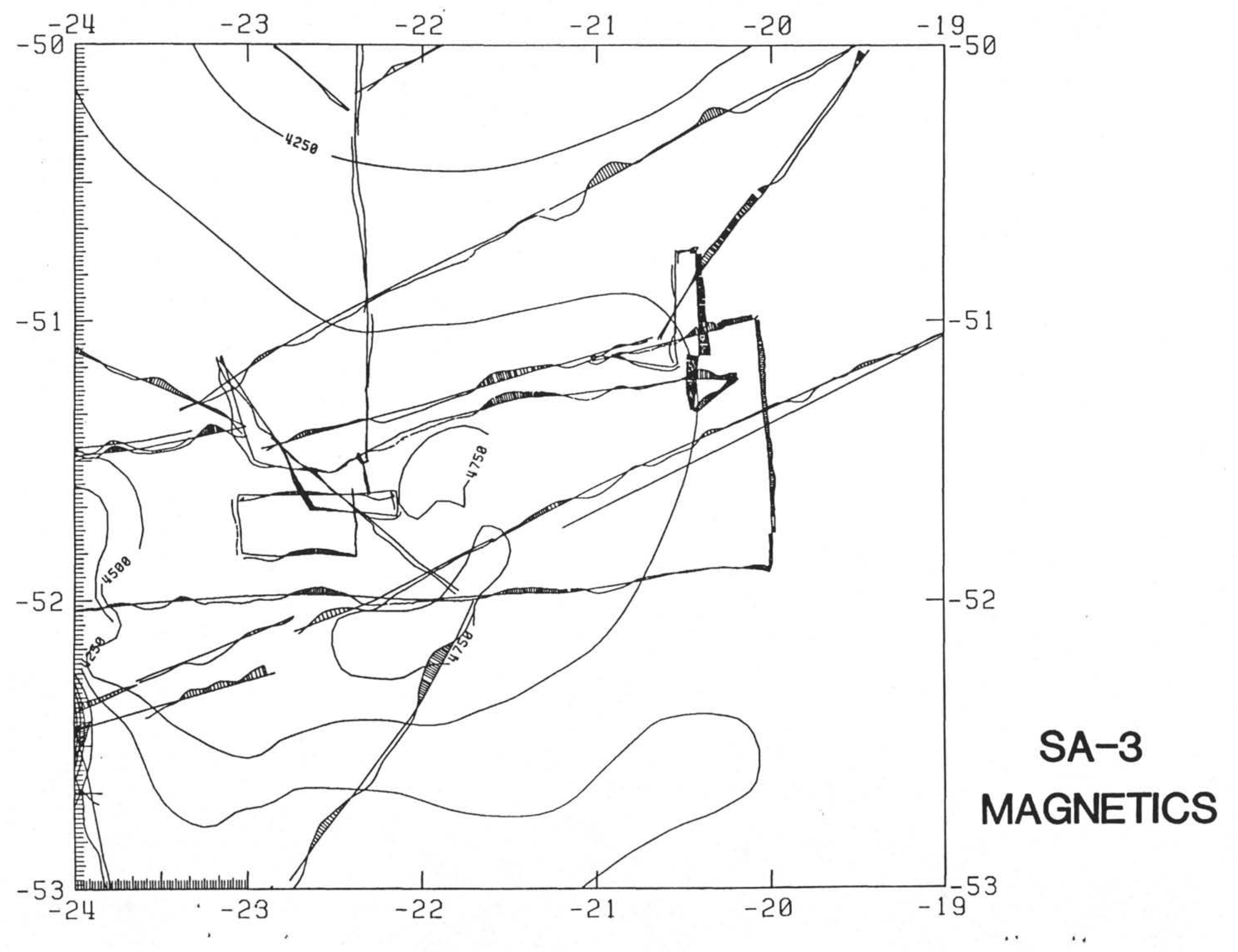




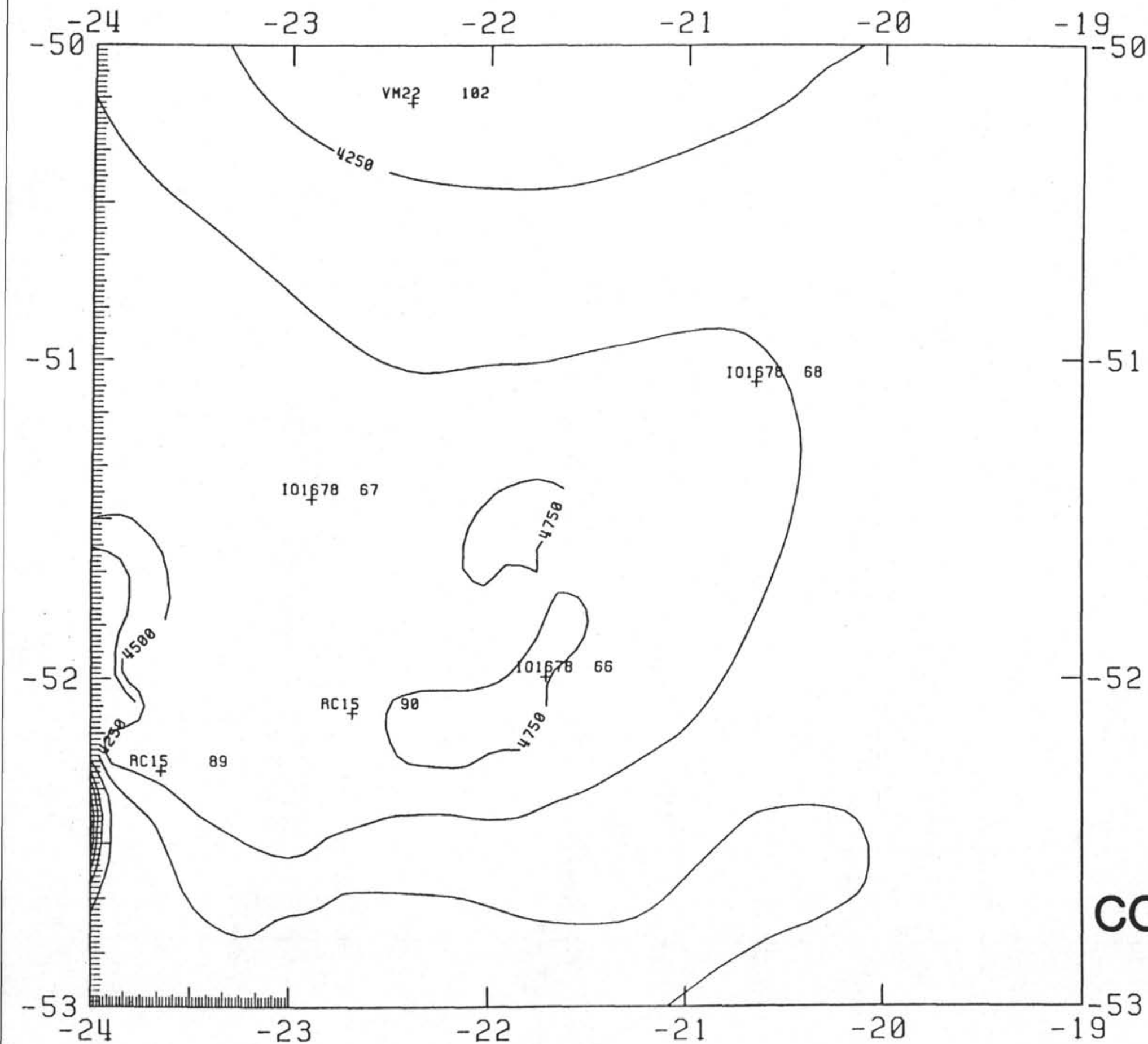

SA-3

CORE LOCATION 


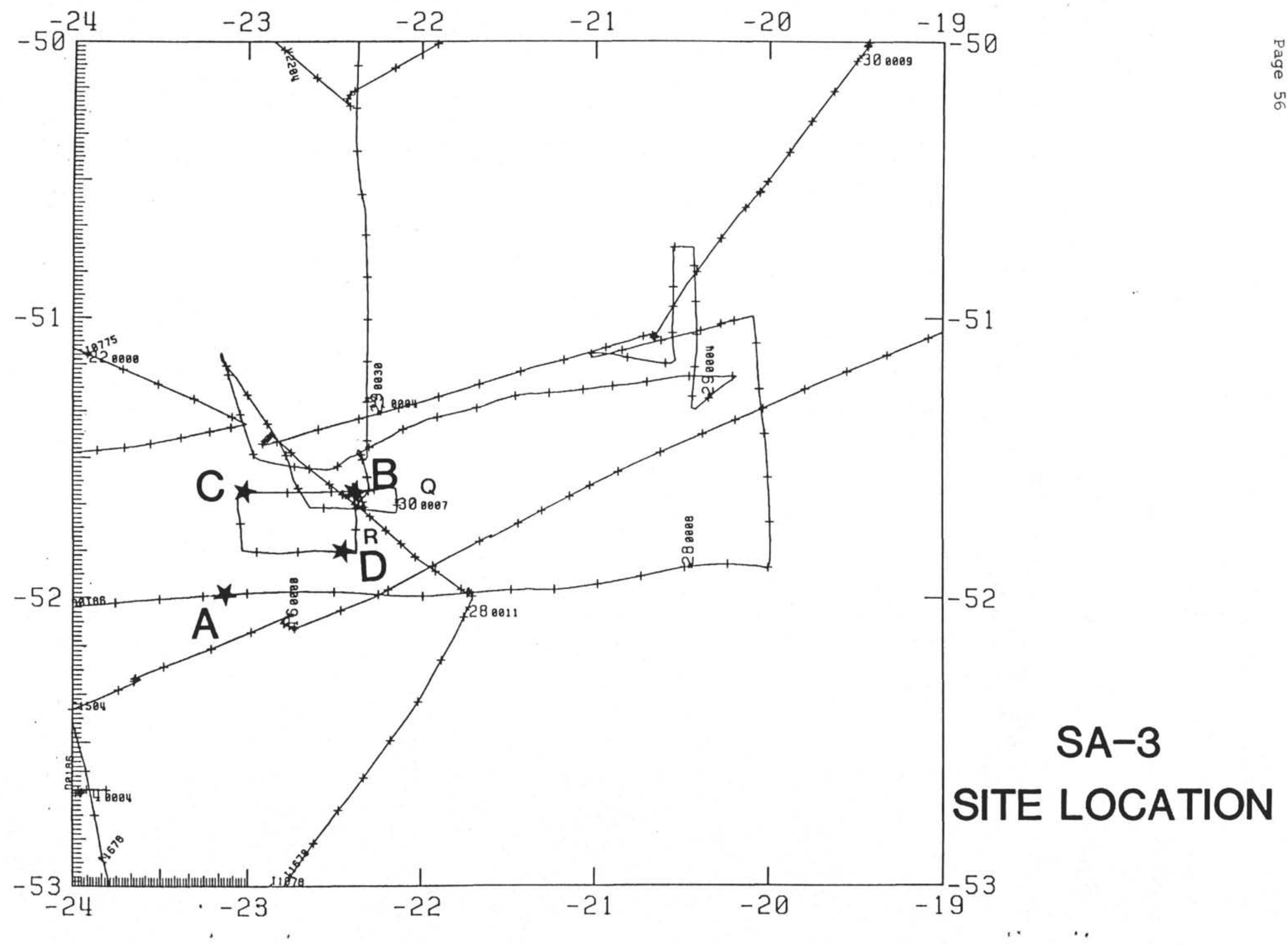


: :

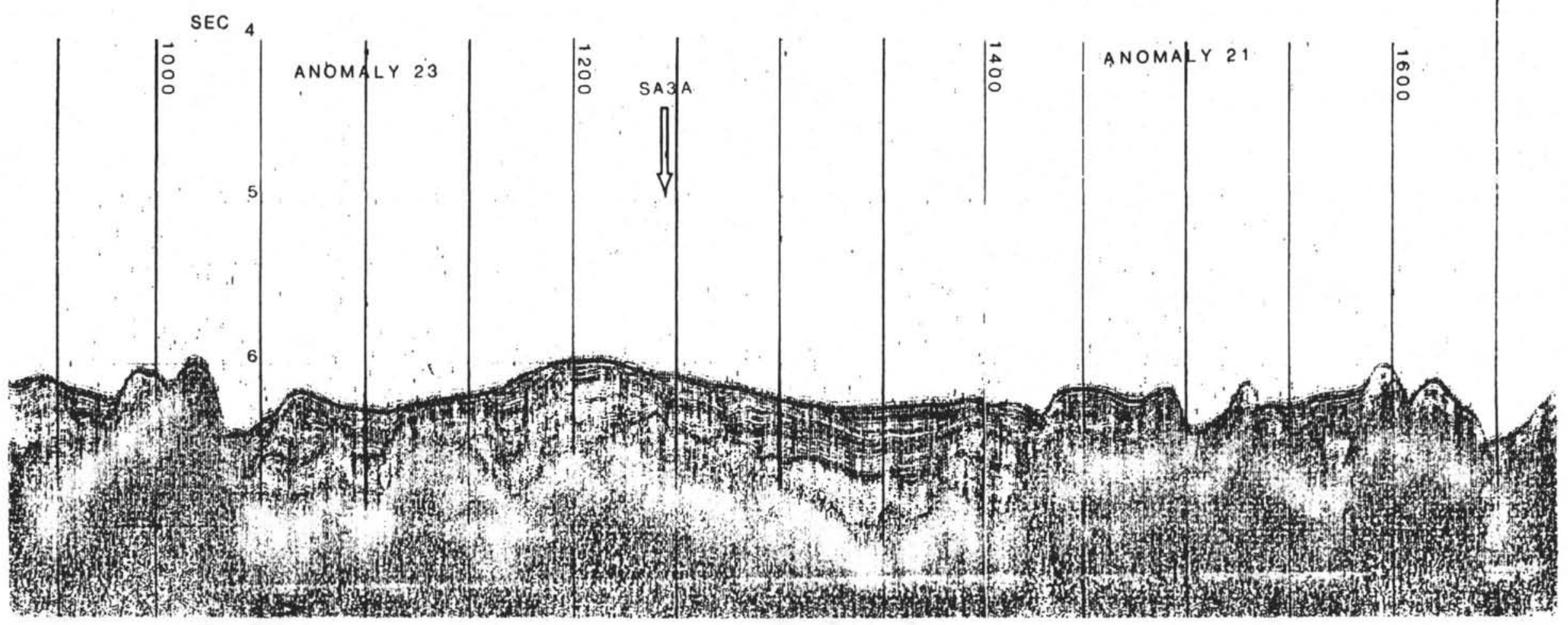




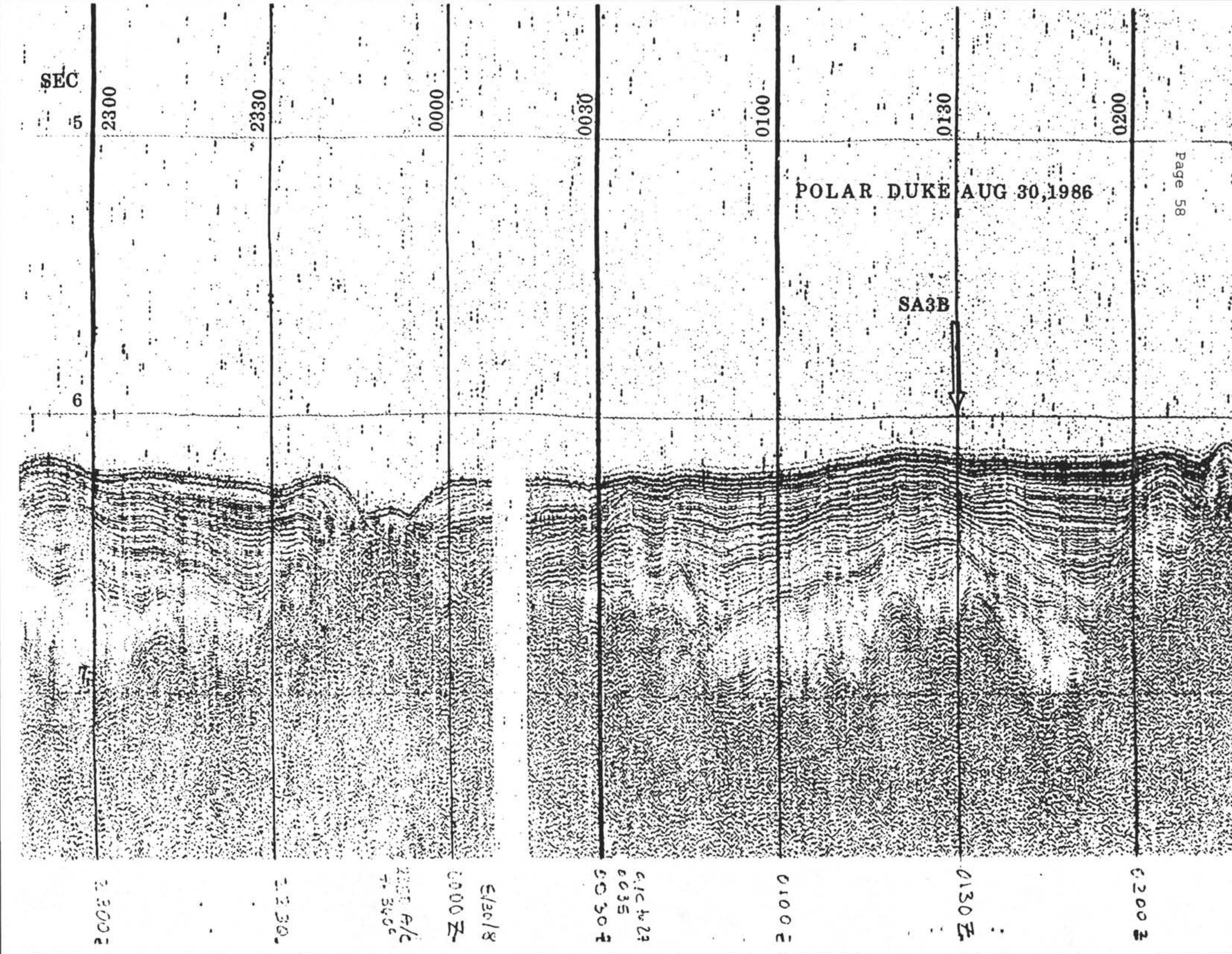




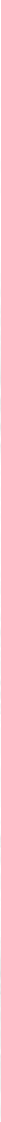




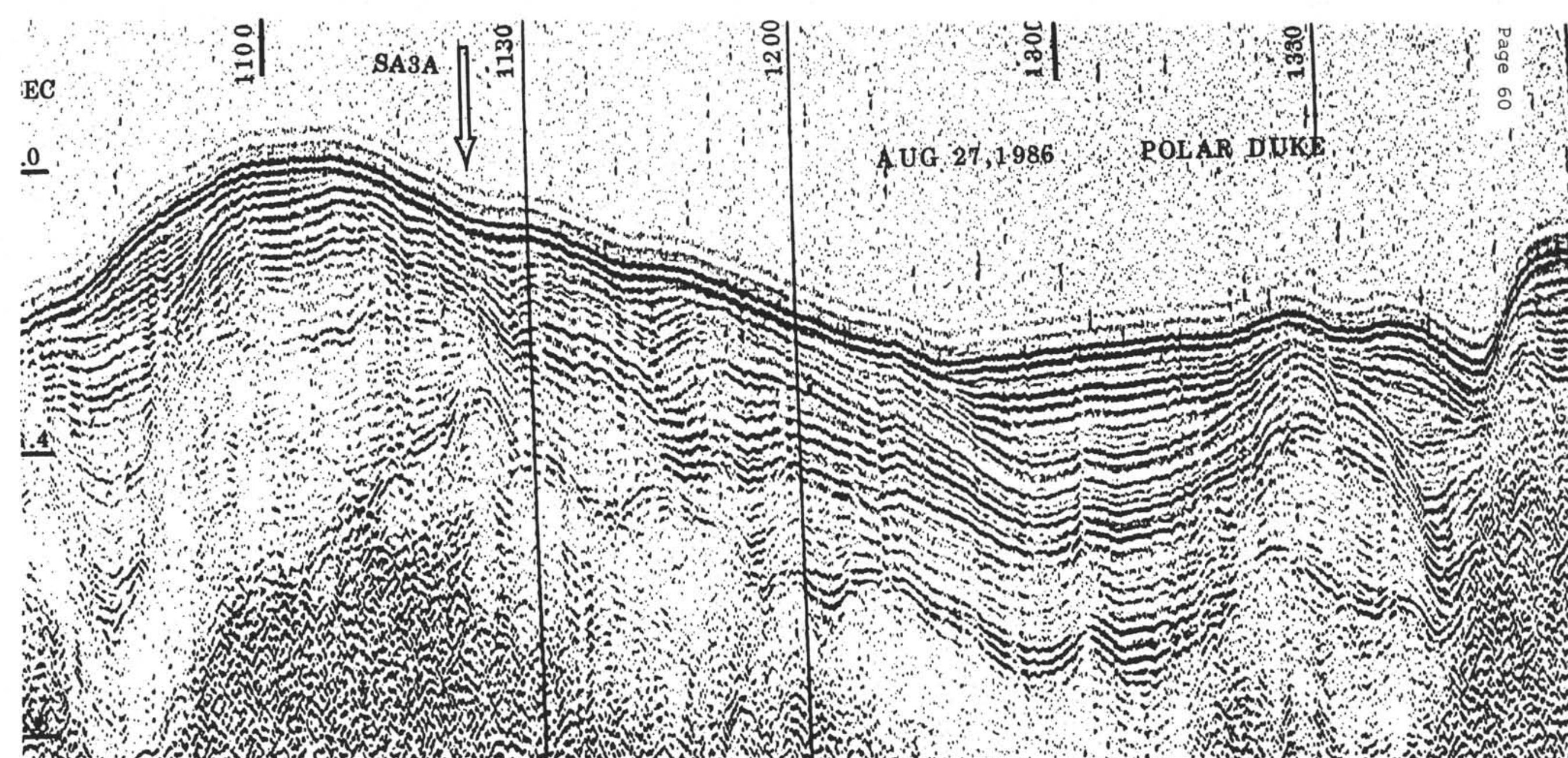

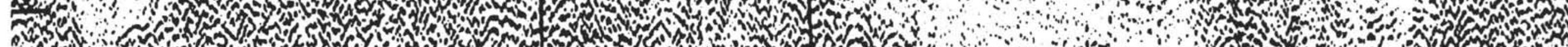

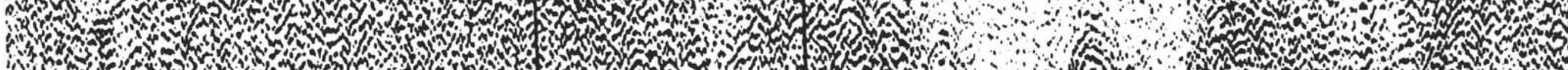

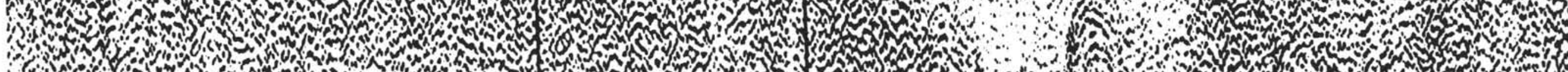
(1) (w) N (1)

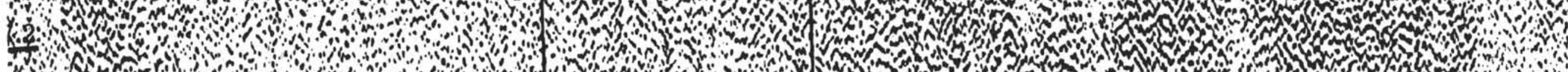

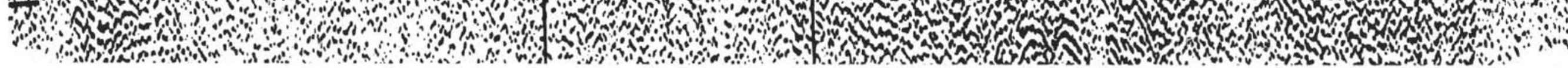




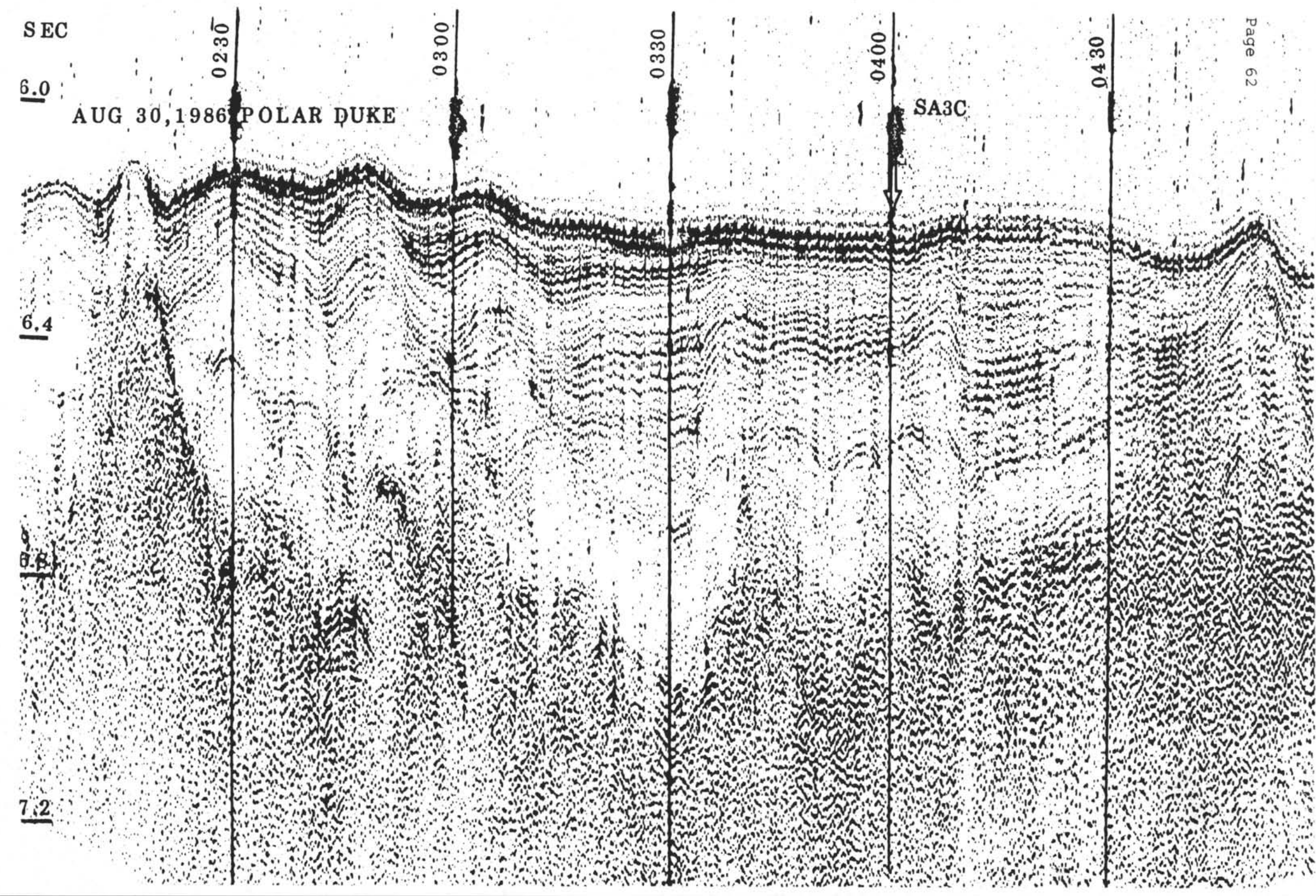




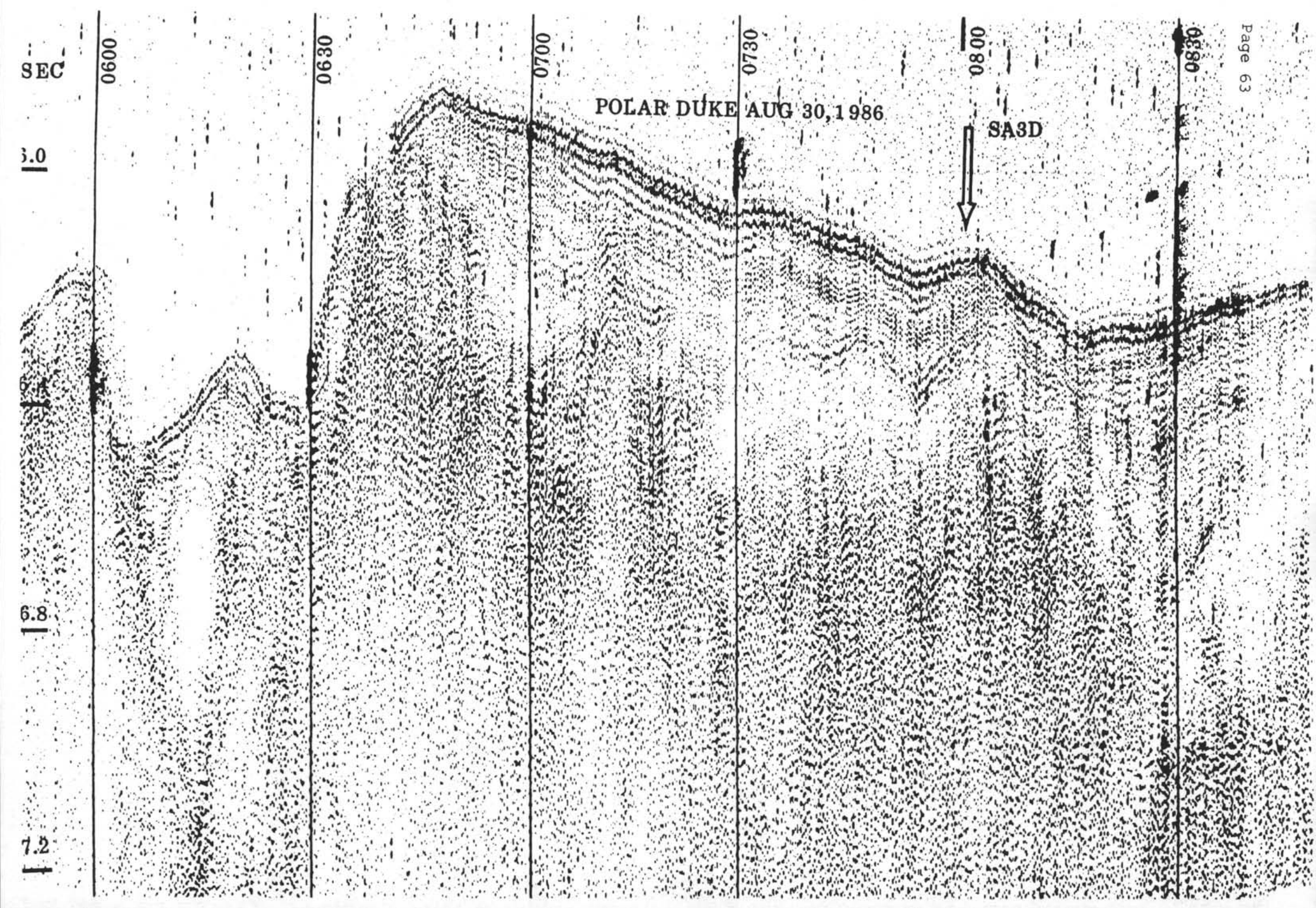


SITE NUMBER: SA5A (Northeast Georgia Rise)

POSITION: $51.945^{\circ} \mathrm{S}, 33.088^{\circ} \mathrm{W}$ SEDIMENT THICKNESS: $800 \mathrm{~m}$

$\underline{\text { WATER DEPTH: }} 1604 \mathrm{~m} \quad$ PRIORITY: II

PROPOSED DRILLING PROGRAM: Double APC, single XCB, approximate penetration $850 \mathrm{~m}$

SEISMIC RECORD: R/V Polar Duke, 0830Z, 9/15/86, profile C-D $\mathrm{R} / \mathrm{V}$ Polar Duke, $1227 \mathrm{Z}, 9 / 15 / 86$, profile E-F

LOGGING: Standard Schlumberger logs, 2 runs, seismic stratigraphy tool and geochemical tool.

OBJECTIVES: Site SA5A is located near the apex of the Northeast Georgia Rise, an oceanic plateau of mid-Cretaceous to Paleocene age. Site SA5A is located on the flank of a basement high with evidence of increasing surface erosion to the south. A hole or a sequence of slightly offset sites may capture the entire section with APC or XCB. Major objectives are to:

-test the hypothesis that the Northeast Georgia Rise is a fossil arc massif generated at a convergent boundary of the Malvinas plate with respect to South America, -determine the duration of possible subduction, -interpret the relationship between Malvinas Plate subduction, North Scotia Ridge deformation, and southern Andean orogeny.

-evaluate Cenozoic shallow to intermediate water mass structure,

-interpret Paleogene and Late Cretaceous vertical water mass gradients (with Sites SA2, SA3, and SA6), -document the development of the ACC,

-document the migration history of the Polar Front.

SEDIMENT TYPE: Calcareous/siliceous ooze and chalk of Paleocene to early Neogene age, zeolitic clay (Eocene). Basal sequence of Upper Cretaceous to lower Paleogene shelf carbonates interbedded with volcanic tephra and subaerial/shallow submarine basalts. 
Page 65

SITE NUMBER: SA5B (Northeast Georgia Rise)

POSITION: $51.550^{\circ} \mathrm{S}, 33.397^{\circ} \mathrm{W} \quad$ SEDIMENT THICKNESS: $700 \mathrm{~m}$

WATER DEPTH: $1714 \mathrm{~m} \quad$ PRIORITY: II

PROPOSED DRILLING PROGRAM: Double APC, single XCB, approximate penetration $750 \mathrm{~m}$.

SEISMIC RECORD: R/V Polar Duke, 0440Z, 9/13/86, profile G-H

$\mathrm{R} / \mathrm{V}$ Polar Duke, 0350Z, 9/15/86, profile A-B

LOGGING: Standard Schlumberger logs, 2 runs, seismic stratigraphy tool and geochemical tool.

OBJECTIVES: Site SA5B is located near the apex of the Northeast Georgia Rise, an oceanic plateau of Mid-Cretaceous to Paleocene age. Site SA5B is located on the flank of a basement high with evidence of increasing surface erosion to the south. A hole or a sequence of slightly offset sites may capture the entire section with APC or XCB. Major objectives are to:

-test the hypothesis that the Northeast Georgia Rise is a fossil arc massif generated at a convergent boundary of the Malvinas plate with respect to South America, -determine the duration of possible subduction, -interpret the relationship between Malvinas plate subduction, North Scotia Ridge deformation, and southern Andean orogeny. -evaluate Cenozoic shallow to intermediate water mass structure,

-interpret $\mathrm{Paleogene}$ and Late Cretaceous vertical water mass gradients (with Sites SA2, SA3, and SA6),

-document the development of the ACC,

-document the migration history of the Polar Front.

SEDIMENT TYPE: Calcareous/siliceous ooze and chalk of Paleogene age, zeolitic clay (Eocene). Basal sequence of Upper Cretaceous to lower Paleogene shelf carbonates interbedded with volcanic tephra and subaerial/shallow submarine basalts. 
SITE NUMBER: SA5C (Northeast Georgia Rise)

POSITION: $51.442^{\circ} \mathrm{S}, 33.430^{\circ} \mathrm{W} \quad$ SEDIMENT THICKNESS: $450 \mathrm{~m}$

WATER DEPTH: $1796 \mathrm{~m} \quad$ PRIORITY: I

PROPOSED DRILLING PROGRAM: Double APC, single XCB, approximate penetration $500 \mathrm{~m}$.

SEISMIC RECORD: R/V Polar Duke, 0432Z, 9/15/86, profile C-D

ARA Islas Orcadas, 2340Z, $11 / 24 / 75$

LOGGING: Standard Schlumberger logs, 2 runs, seismic stratigraphy tool and geochemical tool.

OBJECTIVES: Site SASC is located near the apex of the Northeast Georgia Rise, an oceanic plateau of mid-Cretaceous to Paleocene age. Site SA5C is located on the flank of a basement high with evidence of increasing surface erosion to the south. A hole or a sequence of slightly offset sites may capture the entire section with APC or XCB. Major objectives are to:

-test the hypothesis that the Northeast Georgia Rise is a fossil arc massif generated at a convergent boundary of the Malvinas plate with respect to South America, -determine the duration of possible subduction, -interpret the relationship between Malvinas plate subduction, North Scotia Ridge deformation, and southern Andean orogeny. -evaluate Cenozoic shallow to intermediate water mass structure,

-interpret Paleogene and Late Cretaceous vertical water mass gradients (with SA2, SA3, and SA6), -document the development of the ACC, -document the migration history of the Polar Front.

SEDIMENT TYPE: Calcareous/siliceous ooze and chalk of Paleogene age, zeolitic clay (Eocene). Basal sequence of Upper Cretaceous to lower Paleogene shelf carbonates interbedded with volcanic tephra and subaerial/shallow submarine basalts. 
SITE NUMBER: SA5D (Northeast Georgia Rise)

POSITION: $51.198^{\circ} \mathrm{S}, 34.084^{\circ} \mathrm{W}$ SEDIMENT THICKNESS: $820 \mathrm{~m}$

WATER DEPTH: $2677 \mathrm{~m} \quad$ PRIORITY : II

PROPOSED DRILLING PROGRAM: Double APC, single XCB, approximate penetration $870 \mathrm{~m}$

SEISMIC RECORD: R/V Polar Duke, 1624Z, 9/13/86

LOGGING: Standard Schlumberger logs, 2 runs, seismic stratigraphy tool and geochemical tool.

OBJECTIVES: Site SA5D is located near the apex of the Northeast Georgia Rise, an oceanic plateau of Mid-Cretaceous to Paleocene age. Site SA5D is located on the flank of a basement high with evidence of increasing surface erosion to the south. A hole or a sequence of slightly of fset sites may capture the entire section with APC or XCB. Major objectives are to:

-test the hypothesis that the Northeast Georgia Rise is a fossil arc massif generated at a convergent boundary of the Malvinas plate with respect to South America, -determine the duration of possible subduction, -interpret the relationship between Malvinas plate subduction, North Scotia Ridge deformation, and southern Andean orogeny. -evaluate Cenozoic shallow to intermediate water mass structure,

-interpret Paleogene and Late Cretaceous vertical water mass gradients (with SA2, SA3, and SA6), -document the development of the ACC, -document the migration history of the Polar Front.

SEDIMENT TYPE: Calcareous/siliceous ooze and chalk of Paleocene to early Neogene age, zeolitic clay (Eocene). Basal sequence of Upper Cretaceous to lower Paleogene shelf carbonates interbedded with volcanic tephra and subaerial/shallow submarine basalts. 


\section{SA-5 SHIPS' TRACKS}

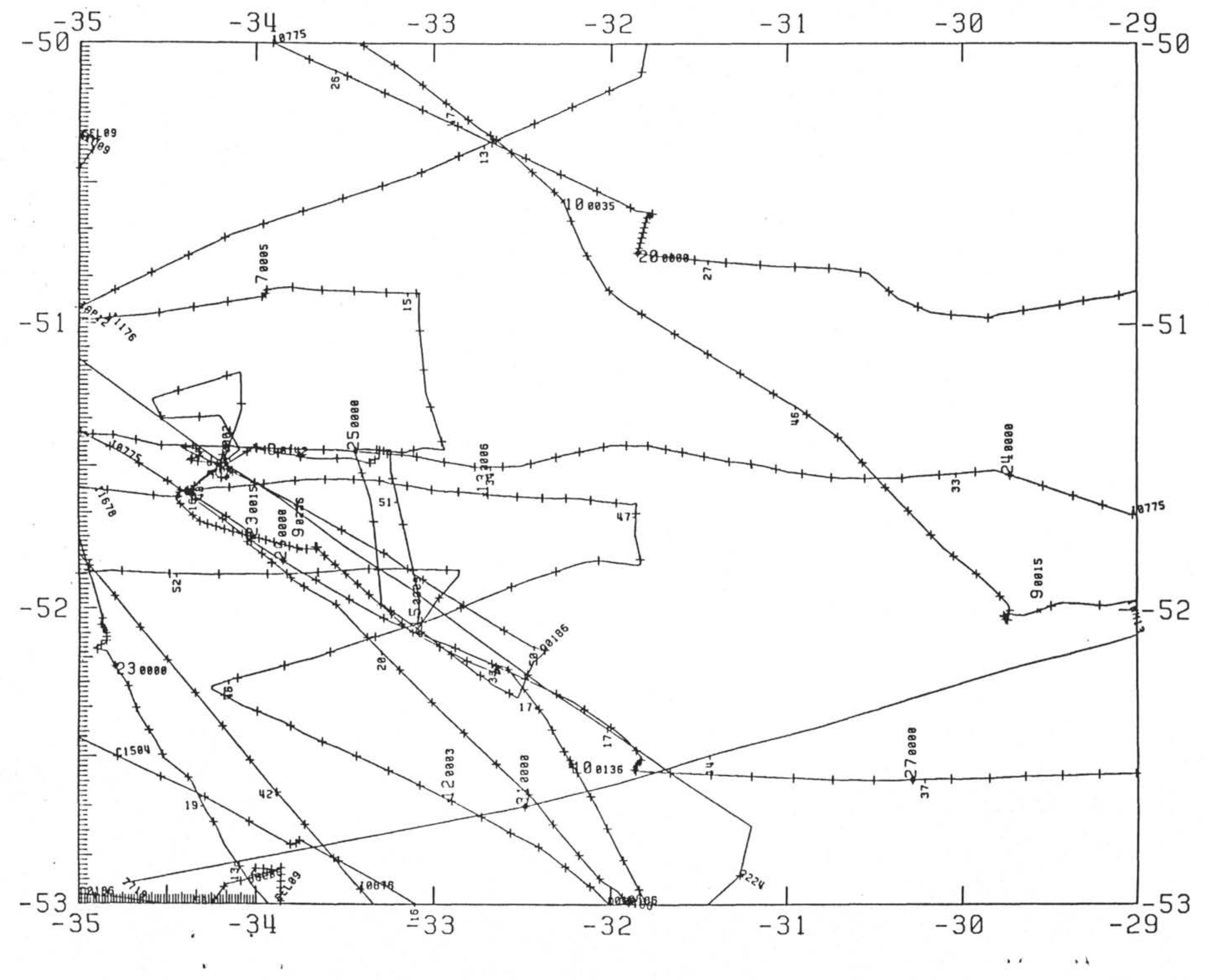


- SA-5 GEBCO BATHYMETRY

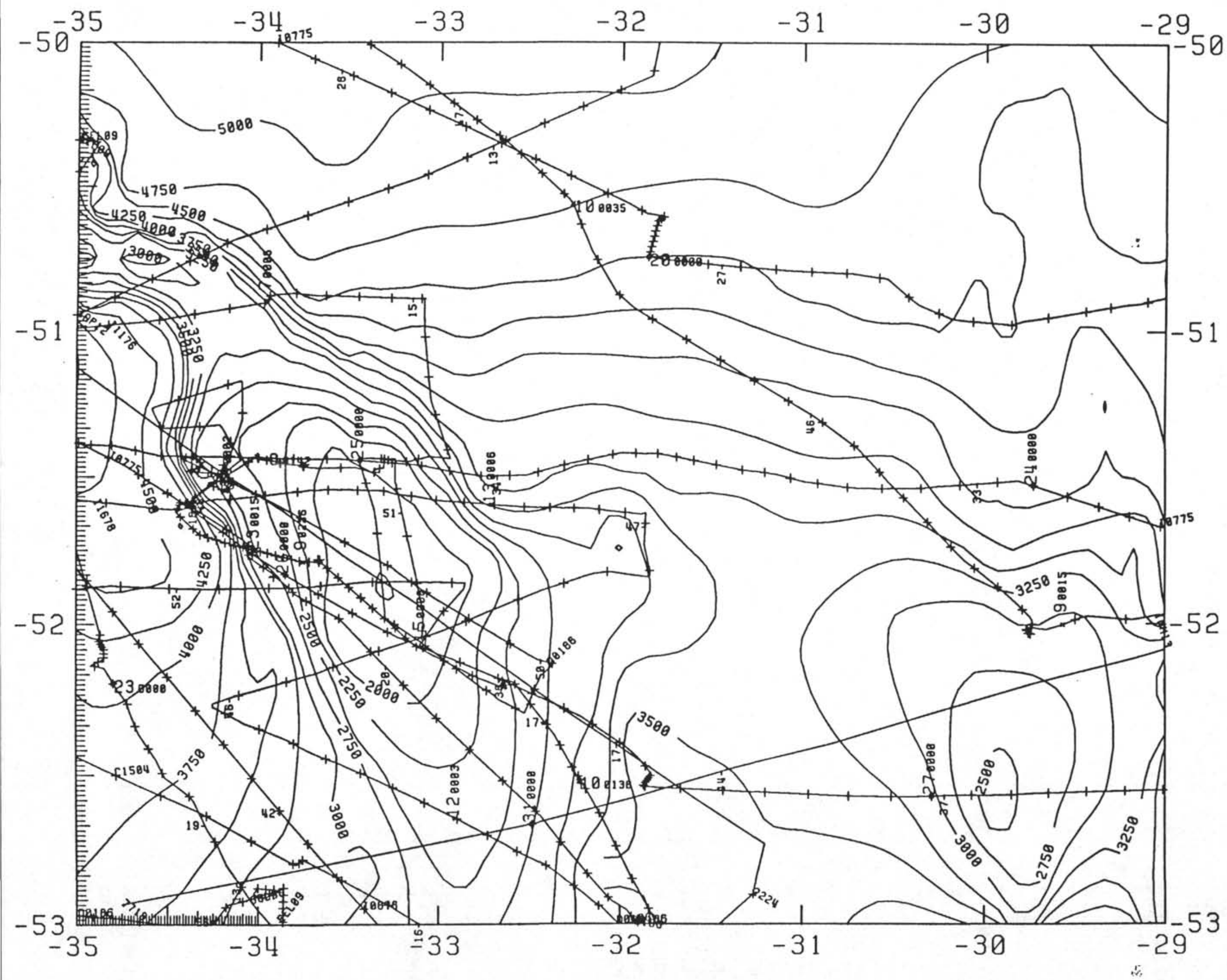




\section{SA-5 MAGNETICS}

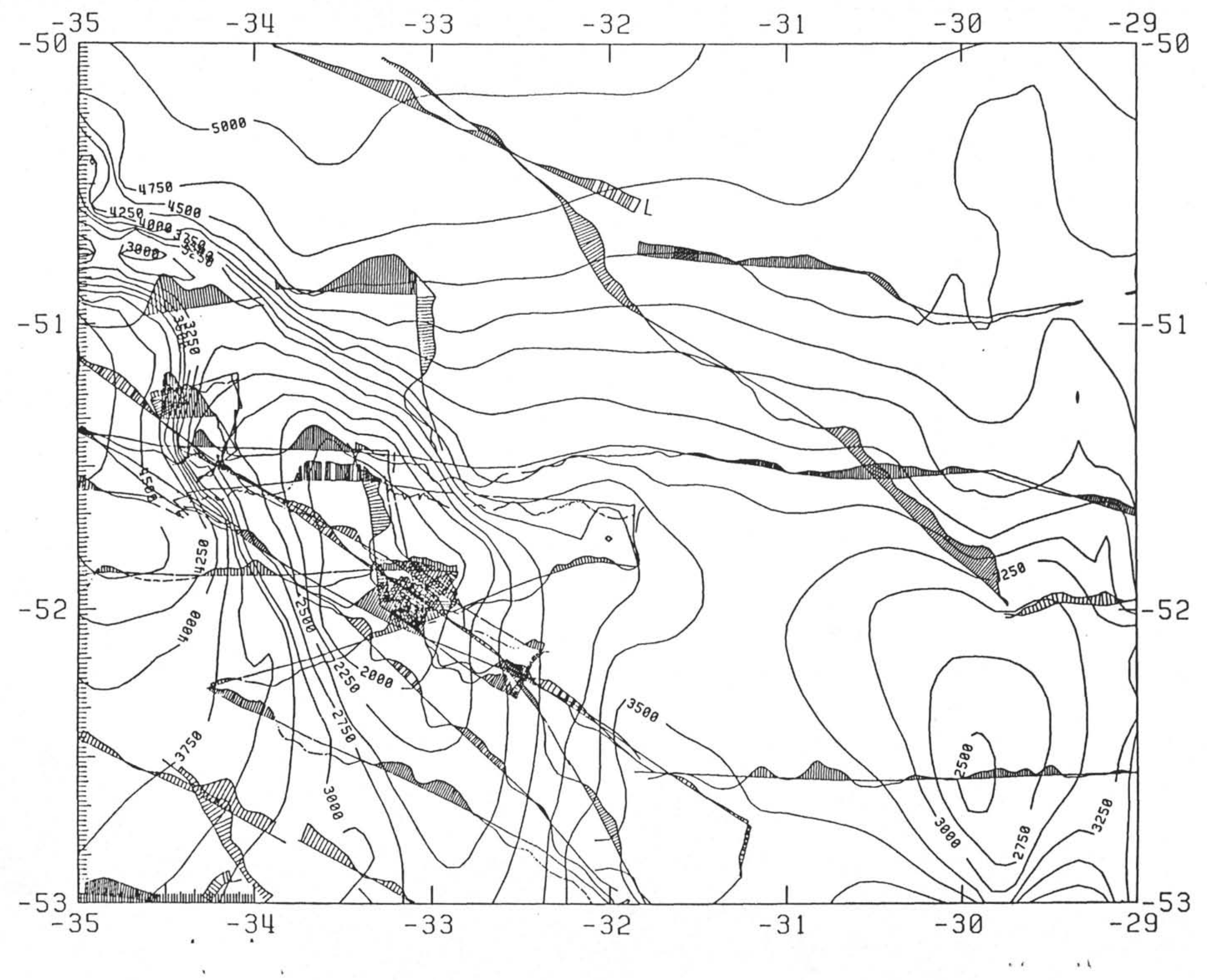




\section{SA-5 CORE LOCATION}

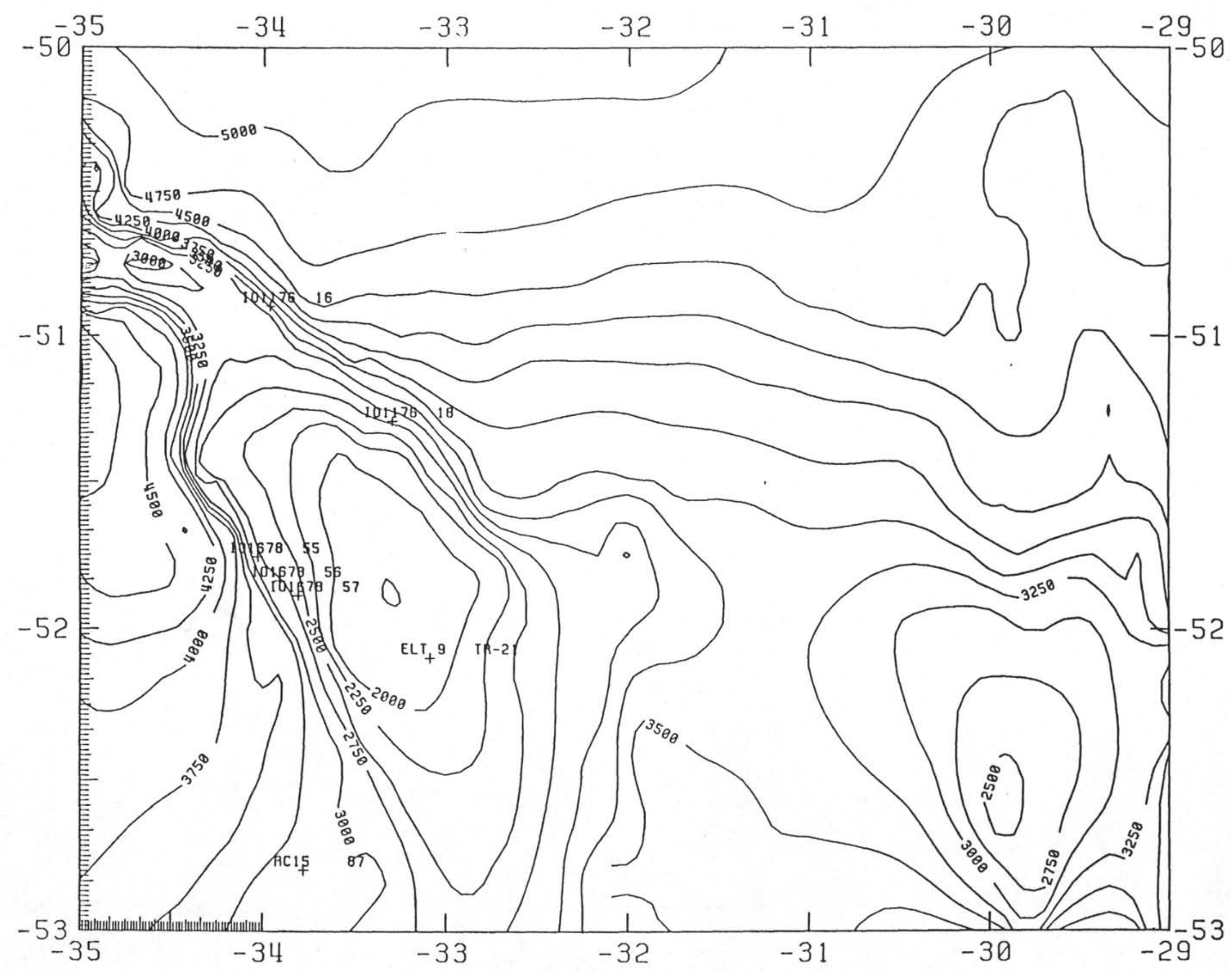




\section{SA-5 SITE LOCATION}

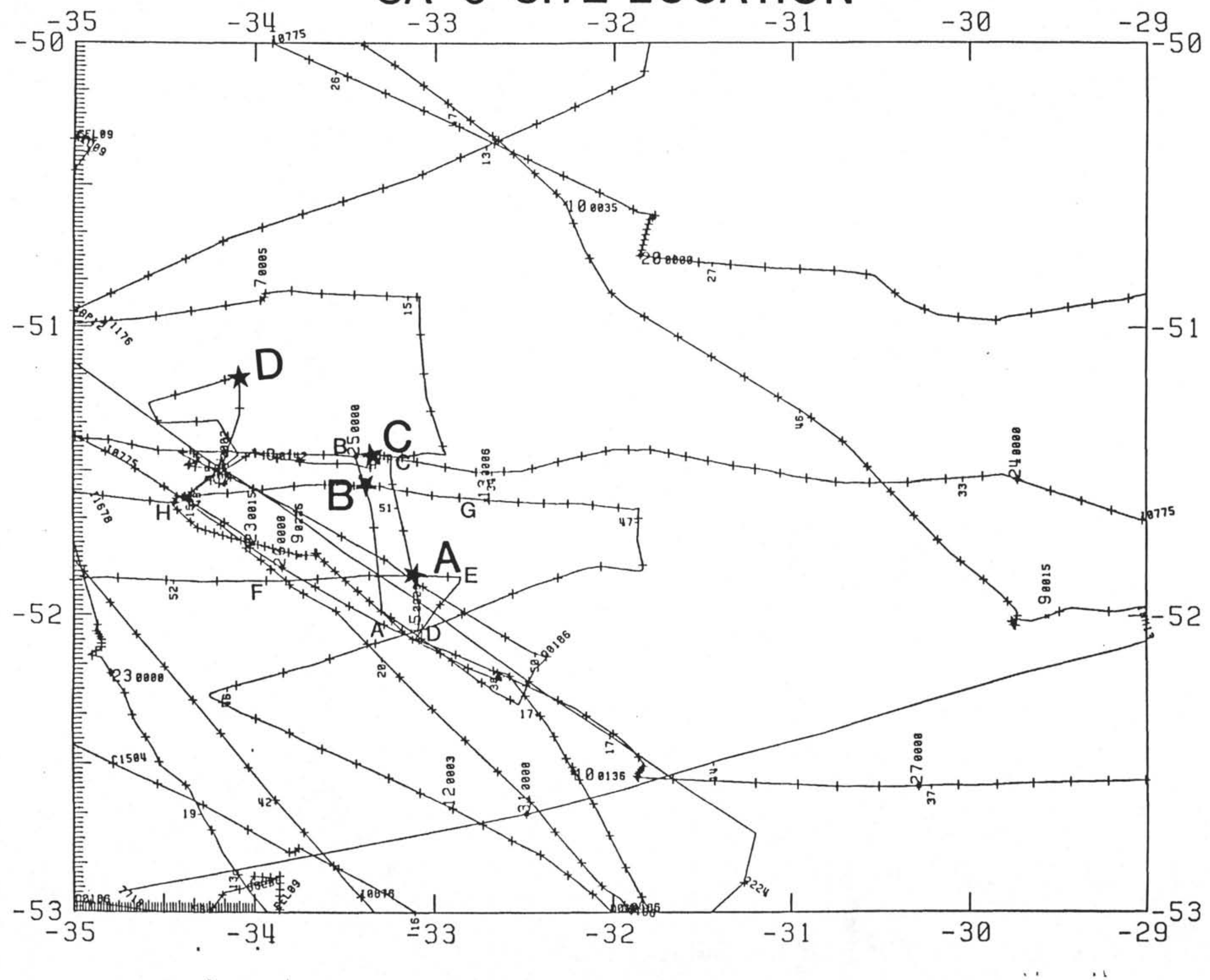




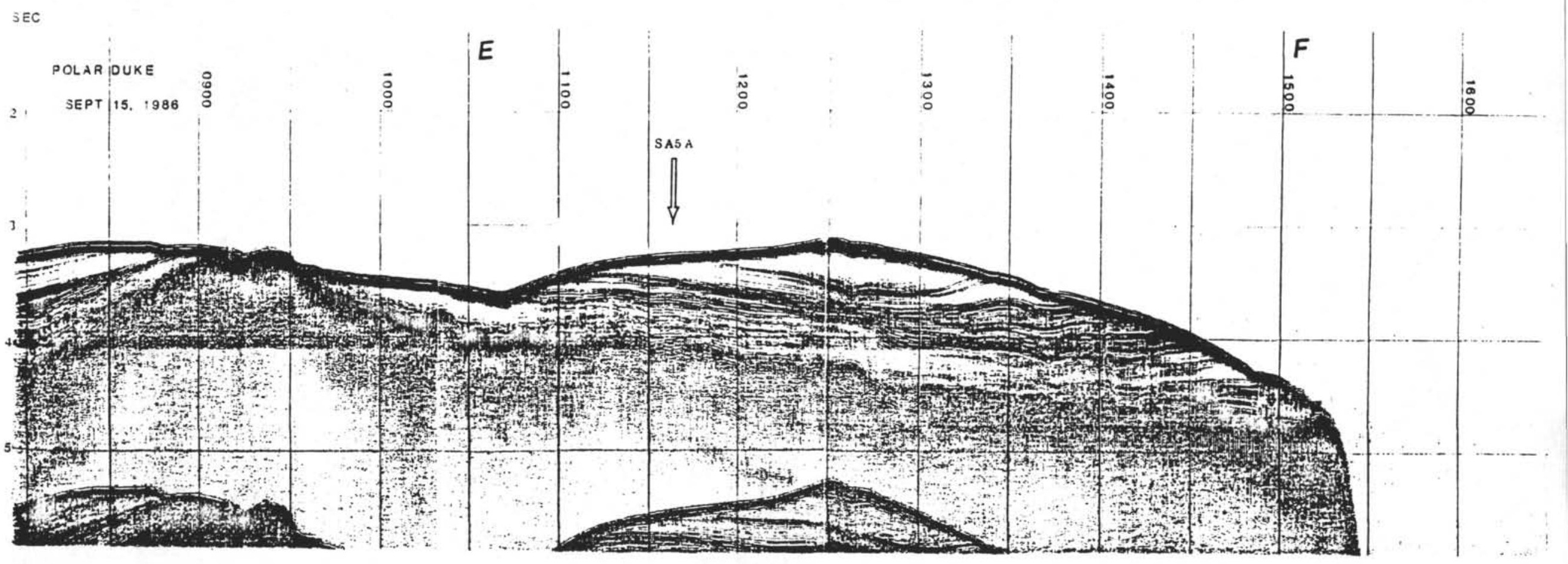




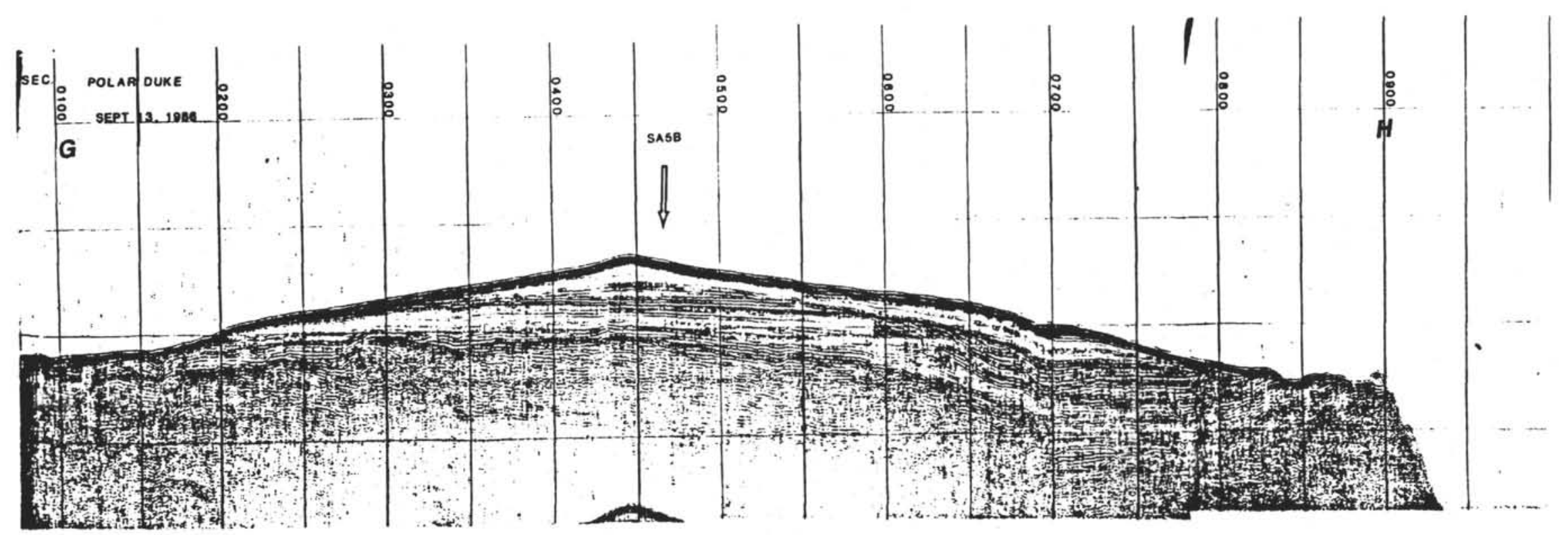




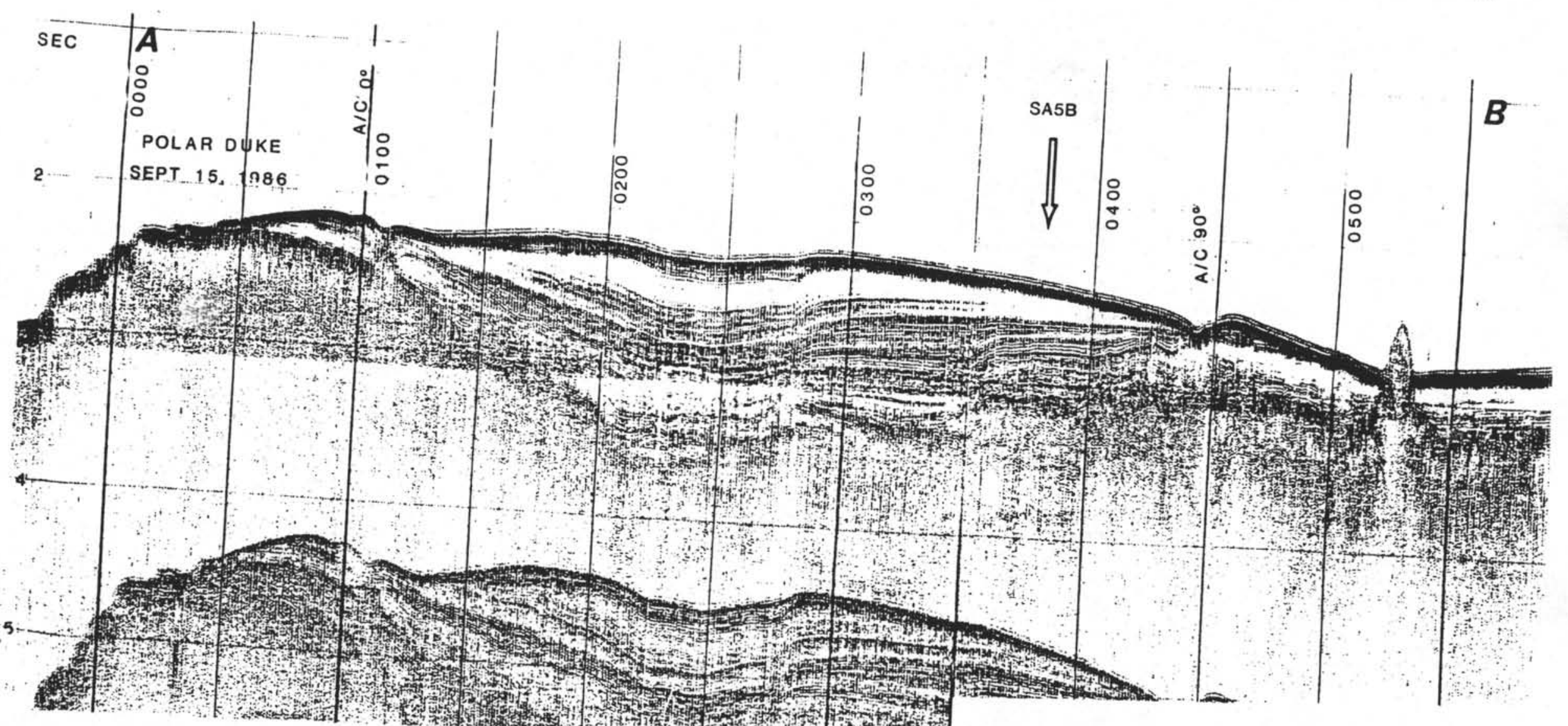




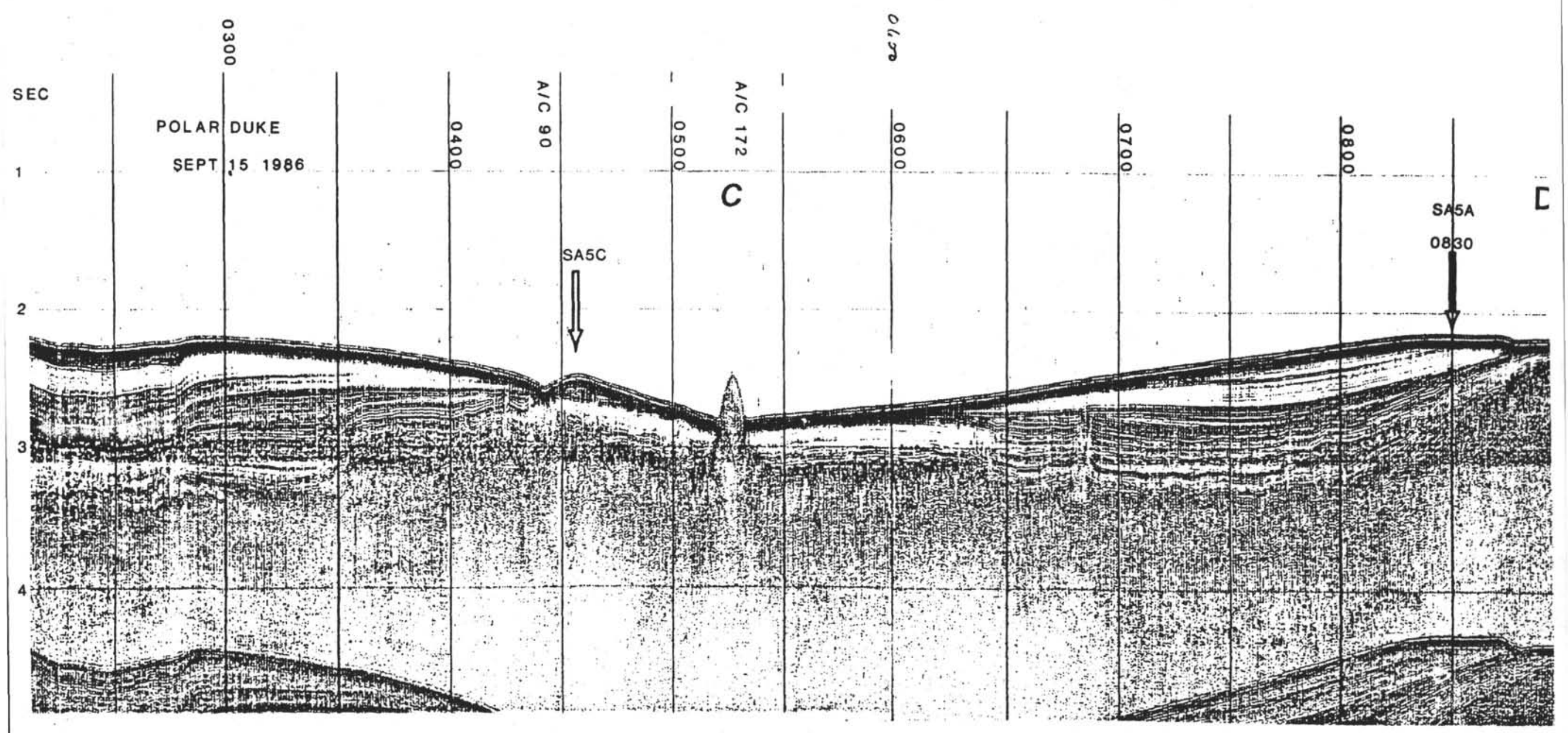




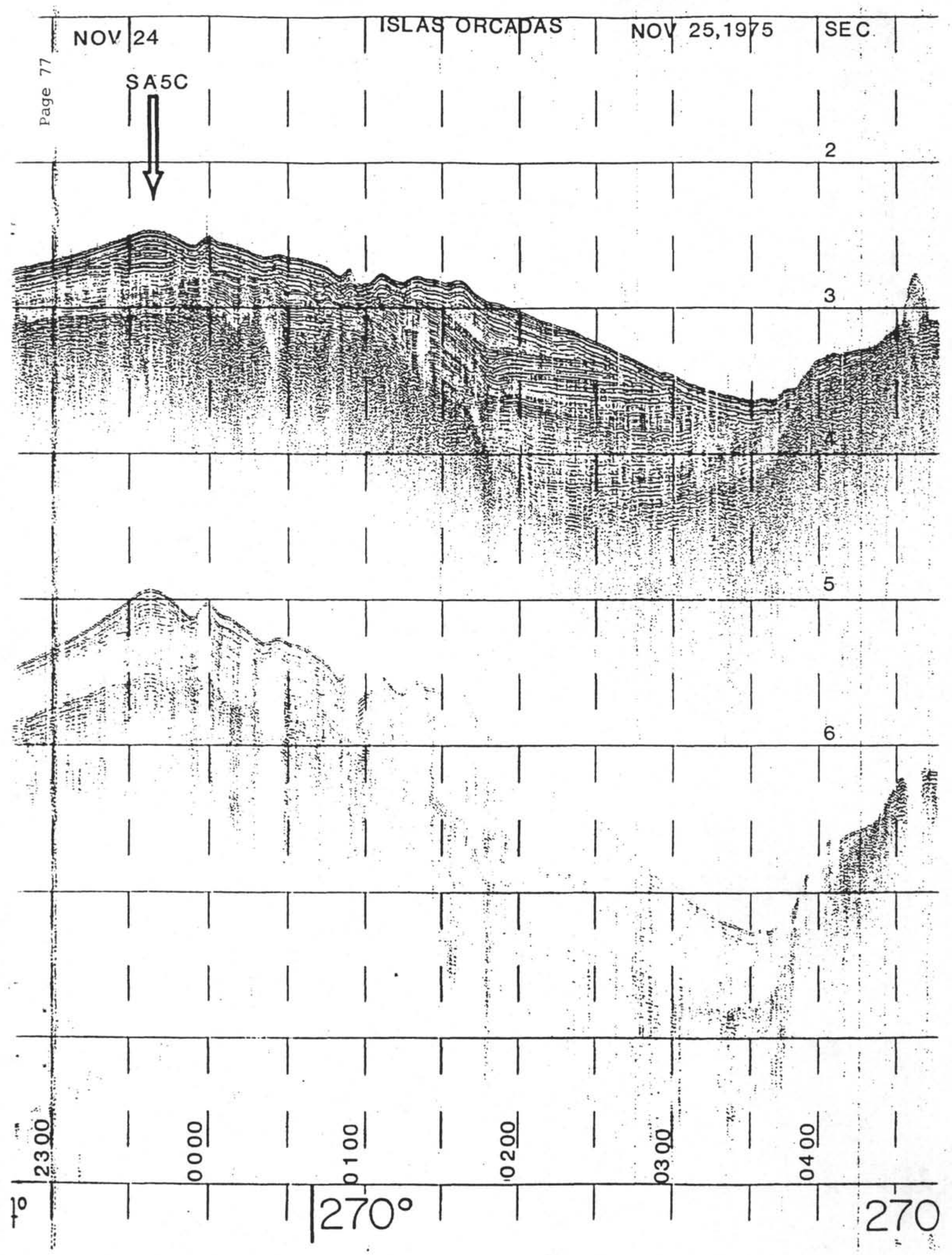




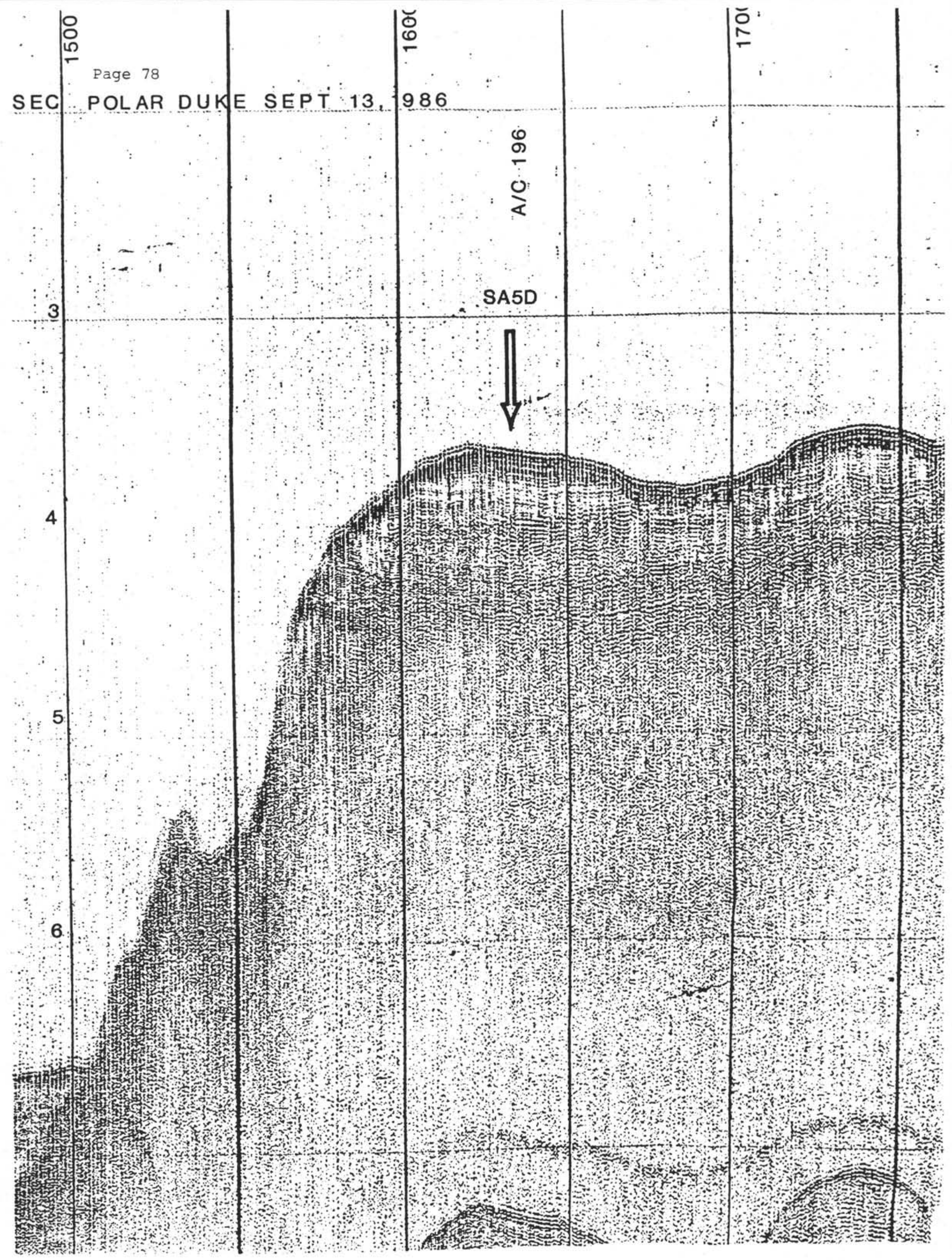


Page 79

SITE NUMBER: SA6A (Islas Orcadas Rise)

POSITION: $51.043^{\circ} \mathrm{S}, 26.083^{\circ} \mathrm{W}$ SEDIMENT THICKNESS: $700 \mathrm{~m}$

WATER DEPTH: $3069 \mathrm{~m} \quad$ PRIORITY: II

PROPOSED DRILLING PROGRAM: Double APC, single XCB, approximate penetration $750 \mathrm{~m}$.

SEISMIC RECORD: R/V Polar Duke, 0730Z, 9/3/86, profile K-L

LOGGING: Standard Schlumberger logs, 2 runs, seismic stratigraphy tool and geochemical tool.

OBJECTIVES: Drilling of the broad and thick sedimentary sequence of the Islas Orcadas Rise has two main objectives: first, to determine the age, nature, and subsidence history of the Rise; and second, to interpret the influence of the shallow Paleogene Islas Orcadas Rise, Meteor Rise, and adjacent fracture zones on the oceanic communication between the Weddell-Scotia Sea and South Atlantic. Other specific objectives include:

-reconstruct shallow to Circumpolar Deep Water (CPDW) structure,

-interpret Paleogene vertical water mass structure (with Sites $\mathrm{SA} 2, \mathrm{SA} 3, \mathrm{SA} 5$ )

-document the development of the ACC and Polar Front history, -examine the geochemistry of aseismic ridges.

Sites A, B, and E provide increased thicknesses of Neogene sequences, while $\mathrm{C}$ and $\mathrm{D}$ provide attenuated sequences for quicker drilling time.

SEDIMENT TYPE: Paleogene-lower Neogene calcareous/siliceous oozes and chalk, pelagic clay (Eocene), basal sequence with shelf carbonates becoming interbedded with volcanic tephra and shallow submarine basalts. 
SITE NUMBER: SA6B (Islas Orcadas Rise)

POSITION: $51.035^{\circ} \mathrm{S}, 26.108^{\circ} \mathrm{W}$ SEDIMENT THICKNESS: $550 \mathrm{~m}$

WATER DEPTH: 3092

PRIORITY: II

PROPOSED DRILLING PROGRAM: Double APC, single XCB, approximate $600 \mathrm{~m}$ penetration.

SEISMIC RECORD: R/V Polar Duke, 2023Z, 9/2/86, profile M-N R/V Polar Duke, 0710Z, 9/3/86, profile K-L

LOGGING: Standard Schlumberger logs, 2 runs, seismic stratigraphy tool and geochemical tool.

OBJECTIVES: Drilling of the broad and thick sedimentary sequence of the Islas Orcadas Rise has two main objectives: first, to determine the age, nature, and subsidence history of the Rise; and second, to interpret the influence of the shallow Paleogene Islas Orcadas Rise, Meteor Rise, and adjacent fracture zones on the oceanic communication between the Weddell-Scotia Sea and South Atlantic. Other specific objectives include: -reconstruct shallow to Circumpolar Deep water (CPDW) structure, -interpret Paleogene vertical water mass structure (with Sites SA2, SA3, SA5)

-document the development of the ACC and Polar Front history, -examine the geochemistry of aseismic ridges. Sites A, B, and E provide increased thicknesses of Neogene sequences, while $C$ and $D$ provide attenuated sequences for quicker drilling time.

SEDIMENT TYPE: Paleogene-lower Neogene calcareous/siliceous oozes and chalk, pelagic clay (Eocene), basal sequence with shelf carbonates becoming interbedded with volcanic tephra and shallow submarine basalts. 
Page 81

SITE NUMBER: SA6C (Islas Orcadas Rise)

POSITION: $50.981^{\circ} \mathrm{S}, 26.247^{\circ} \mathrm{W}$ SEDIMENT THICKNESS: $450 \mathrm{~m}$

WATER DEPTH: $3098 \mathrm{~m} \quad$ PRIORITY: II

PROPOSED DRILLING PROGRAM: Double APC, single XCB, approximate penetration $500 \mathrm{~m}$.

SEISMIC RECORD: R/V Polar Duke, 0600Z, 9/3/86, profile K-L

LOGGING: Standard Schlumberger logs, 2 runs, seismic stratigraphy tool and geochemical tool.

OBJECTIVES: Drilling of the broad and thick sedimentary sequence of the Islas Orcadas Rise has two main objectives: first, to determine the age, nature, and subsidence history of the Rise; and second, to interpret the influence of the shallow Paleogene Islas Orcadas Rise, Meteor Rise, and adjacent fracture zones on the oceanic communication between the Weddell-Scotia Sea and South Atlantic. Other specific objectives include: -reconstruct shallow to Circumpolar Deep Water (CPDW) structure, -interpret $\mathrm{Paleogene}$ vertical water mass structure (with Sites SA2, SA3, SA5)

-document the development of the ACC and Polar Front history, -examine the geochemistry of aseismic ridges.

Sites A, B, and E provide increased thicknesses of Neogene sequences, while $C$ and $D$ provide attenuated sequences for quicker drilling time.

SEDIMENT TYPE: Paleogene Neogene calcareous/siliceous oozes and chalk, pelagic clay (Eocene), basal sequence with shelf carbonates becoming interbedded with volcanic tephra and shallow submarine basalts. 
SITE NUMBER: SA6D (Islas Orcadas Rise)

POSITION: $51.042^{\circ} \mathrm{S}, 25.883^{\circ} \mathrm{W}$ SEDIMENT THICKNESS: $600 \mathrm{~m}$

WATER DEPTH: $3096 \mathrm{~m} \quad$ PRIORITY: II

PROPOSED DRILLING PROGRAM: Double APC, single XCB, approximate penetration $650 \mathrm{~m}$.

SEISMIC RECORD: R/V Polar Duke, 1921Z, 9/2/86, profile M-NN..

LOGGING: Standard Schlumberger logs, 2 runs, seismic stratigraphy tool and geochemical tool.

OBJECTIVES: Drilling of the broad and thick sedimentary sequence of the Islas Orcadas Rise has two main objectives: first, to determine the age, nature, and subsidence history of the Rise; and second, to interpret the influence of the shallow Paleogene Islas Orcadas Rise, Meteor Rise, and adjacent fracture zones on the oceanic communication between the Weddell-Scotia Sea and South Atlantic. Other specific objectives include:

-reconstruct shallow to Circumpolar Deep Water (CPDW) structure, -interpret Paleogene vertical water mass structure (with Sites SA2, SA3, SA5)

-document the development of the ACC and Polar Front history, -examine the geochemistry of aseismic ridges.

Sites A, B, and E provide increased thicknesses of Neogene sequences, while $C$ and $D$ provide attenuated sequences for quicker drilling time.

SEDIMENT TYPE: Paleogene-lower Neogene calcareous/siliceous oozes and chalk, pelagic clay (Eocene), basal sequence with shelf carbonates becoming interbedded with volcanic tephra and shallow submarine basalts. 
SITE NUMBER: SA6E (Islas Orcadas Rise)

POSITION: $51.204^{\circ} \mathrm{S}, 26.075^{\circ} \mathrm{W}$ SEDIMENT THICKNESS: $750 \mathrm{~m}$

WATER DEPTH: $3131 \mathrm{~m} \quad$ PRIORITY: II

PROPOSED DRILLING PROGRAM: Double APC, single XCB, approximate penetration $800 \mathrm{~m}$.

SEISMIC RECORD: R/V Polar Duke, 0816Z, 9/2/86, profile I-J

LOGGING: Standard Schlumberger logs, 2 runs, seismic stratigraphy tool and geochemical tool.

OBJECTIVES: Drilling of the broad and thick sedimentary sequence of the Islas Orcadas Rise has two main objectives: first, to determine the age, nature, and subsidence history of the Rise; and second, to interpret the influence of the shallow Paleogene Islas Orcadas Rise, Meteor Rise, and adjacent fracture zones on the oceanic communication between the Weddell-Scotia Sea and South Atlantic. Other specific objectives include:

-reconstruct shallow to Circumpolar Deep Water (CPDW) structure, -interpret Paleogene vertical water mass structure (with Sites SA2, SA3, SA5)

-document the development of the ACC and Polar Front history, -examine the geochemistry of aseismic ridges.

Sites A, B, and E provide increased thicknesses of Neogene sequences, while $C$ and $D$ provide attenuated sequences for quicker drilling time.

SEDIMENT TYPE: Paleogene-lower Neogene calcareous/siliceous oozes and chalk, pelagic clay (Eocene), basal sequence with shelf carbonates becoming interbedded with volcanic tephra and shallow submarine basalts. 


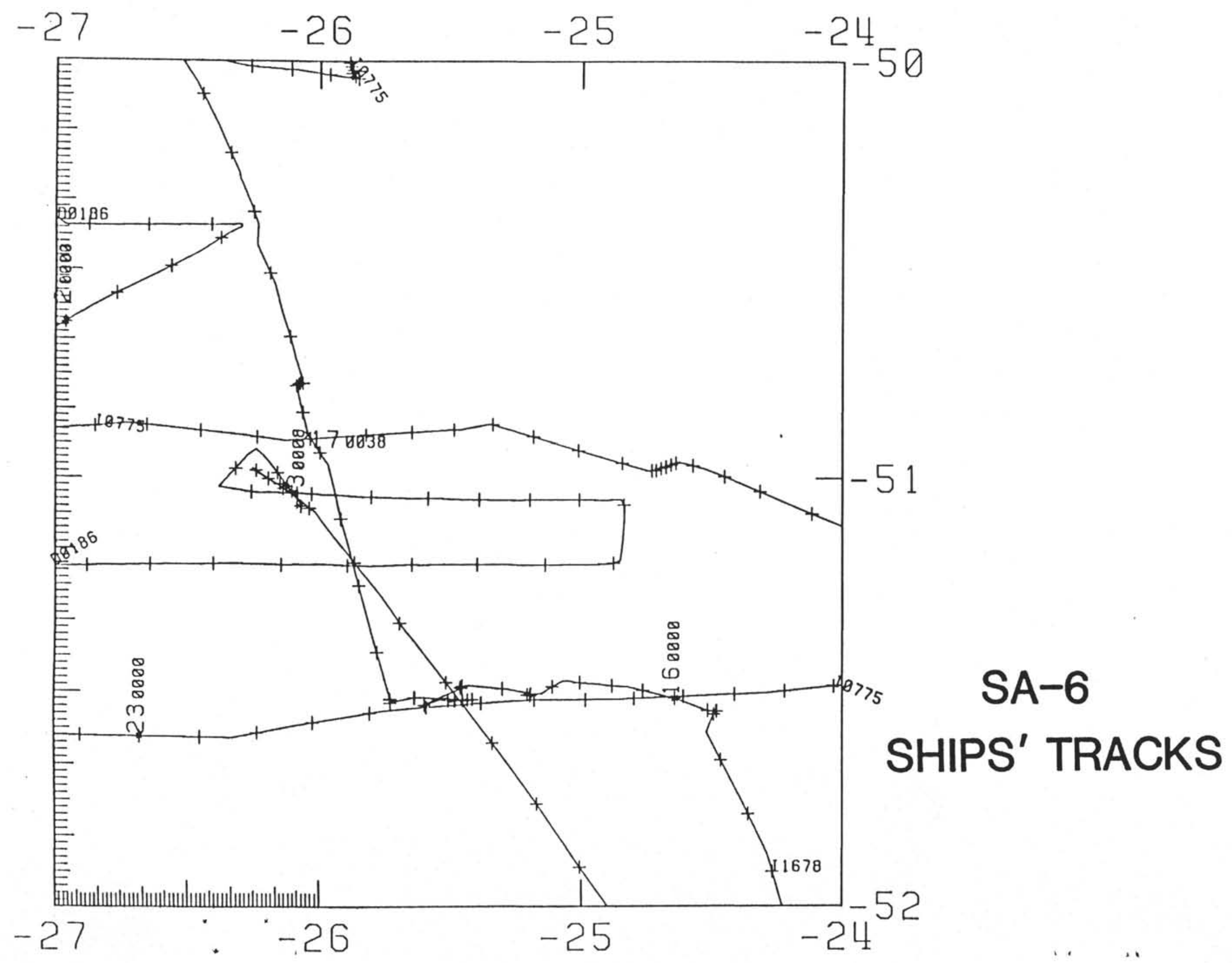




$$
\begin{array}{llll}
-27 & -26 & -25 & -24
\end{array}
$$

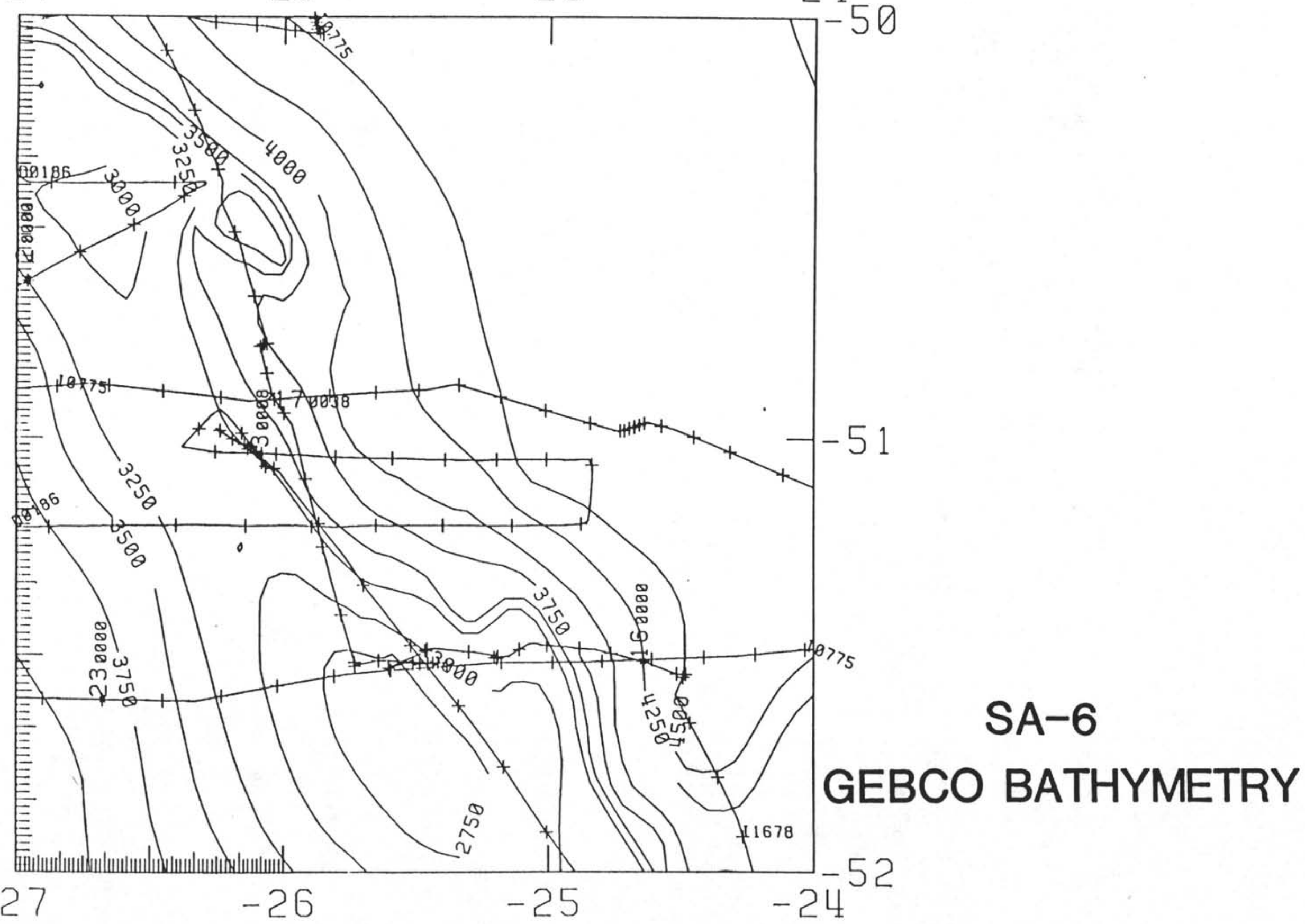




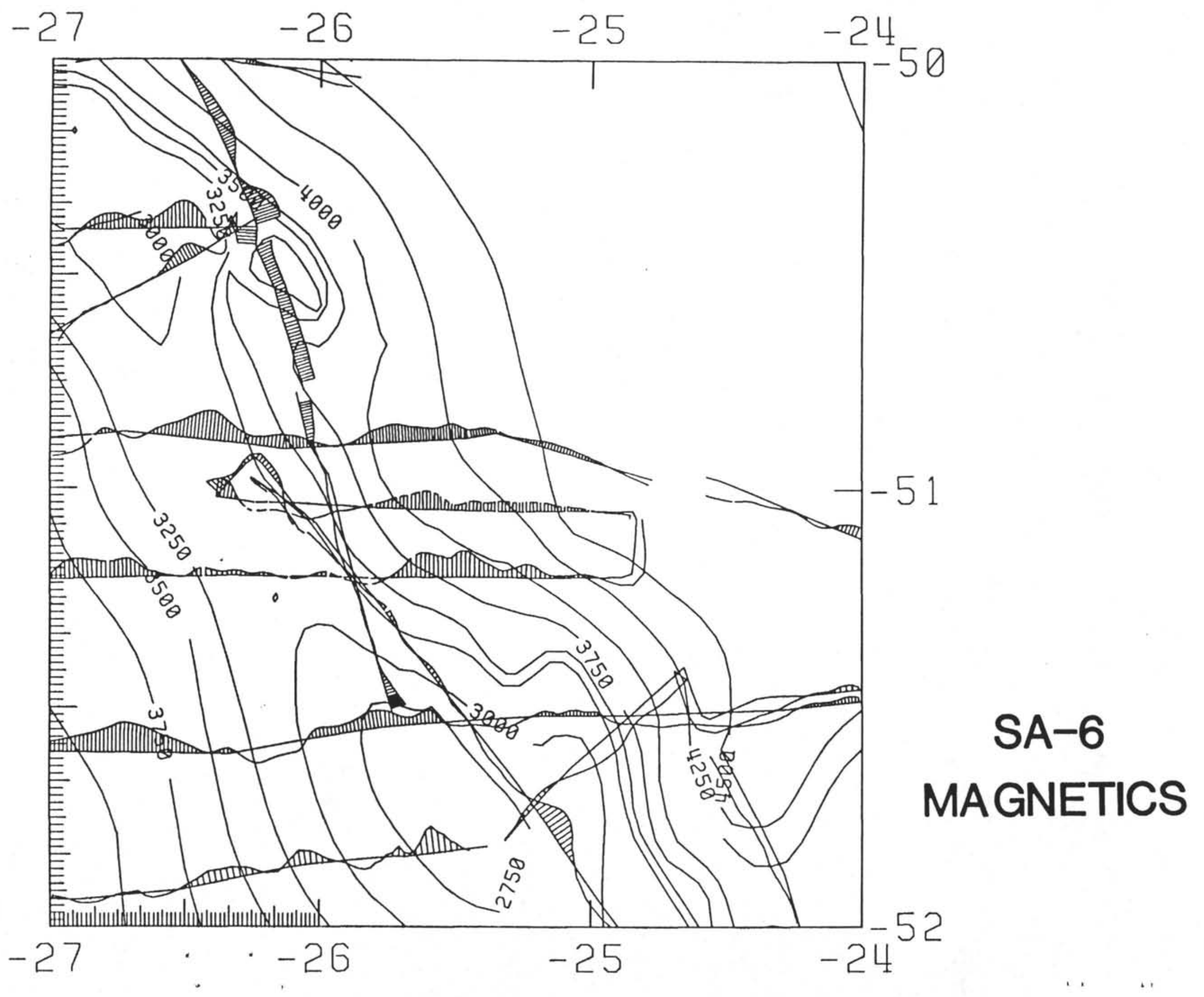




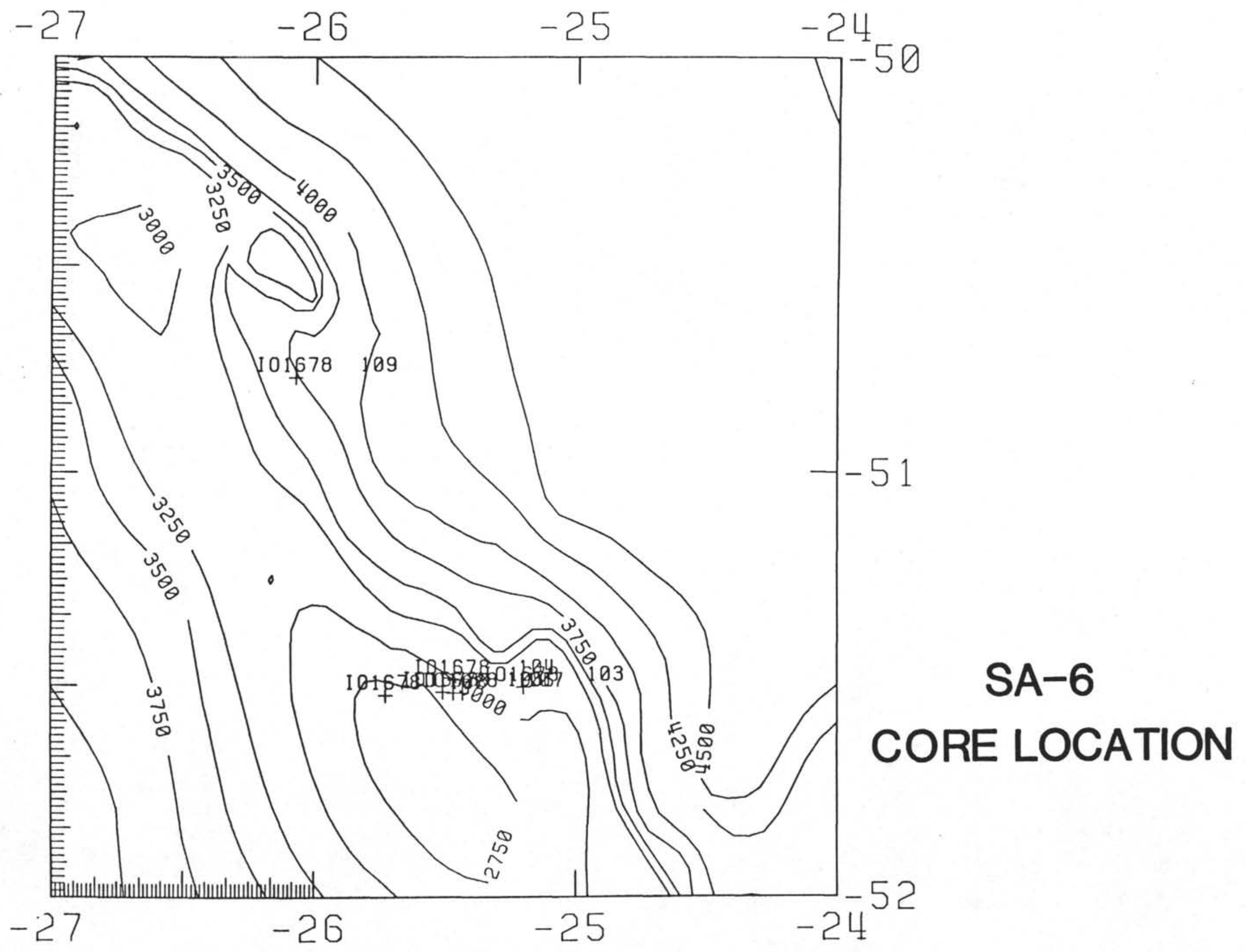




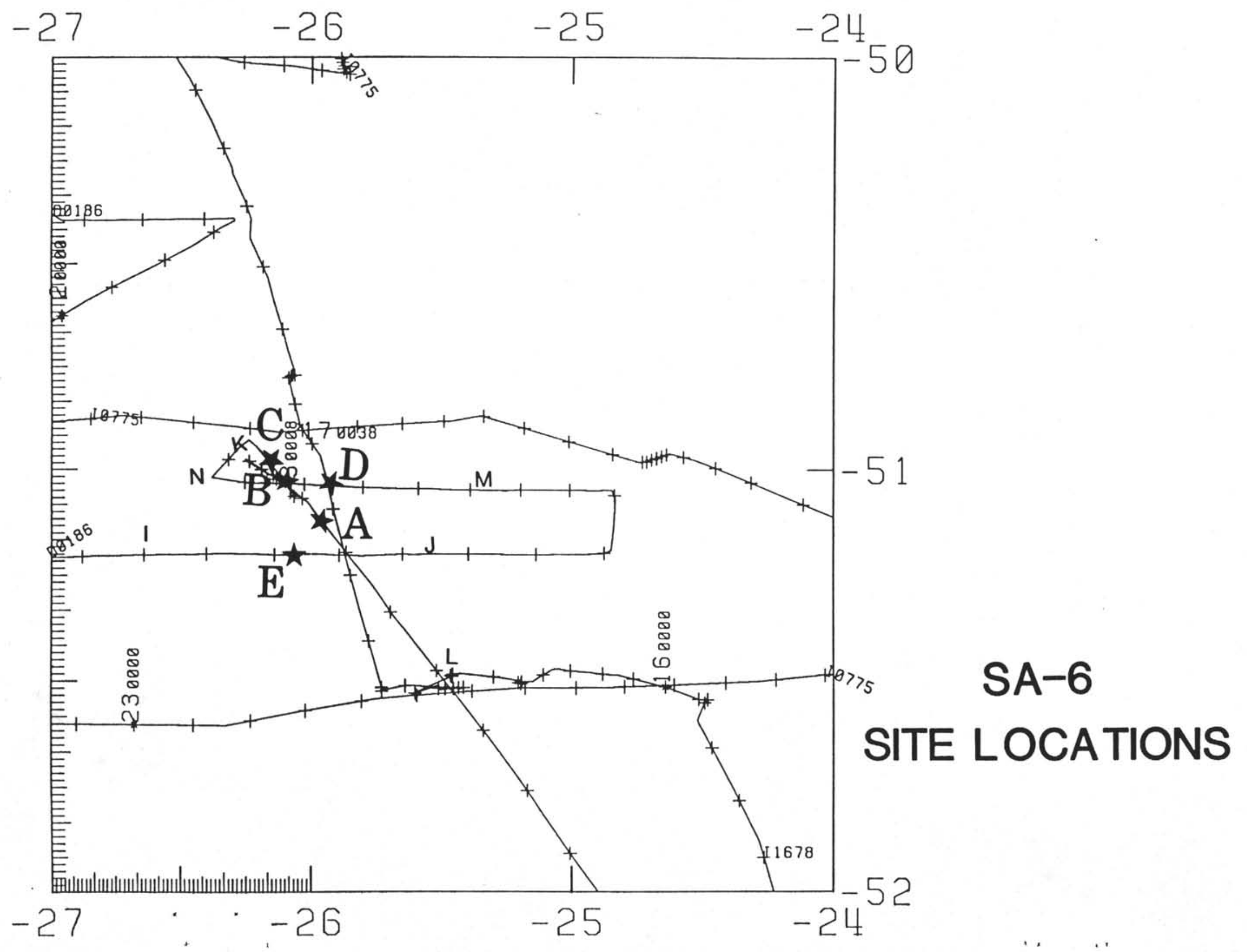




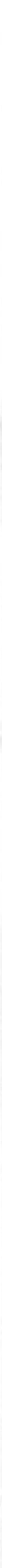




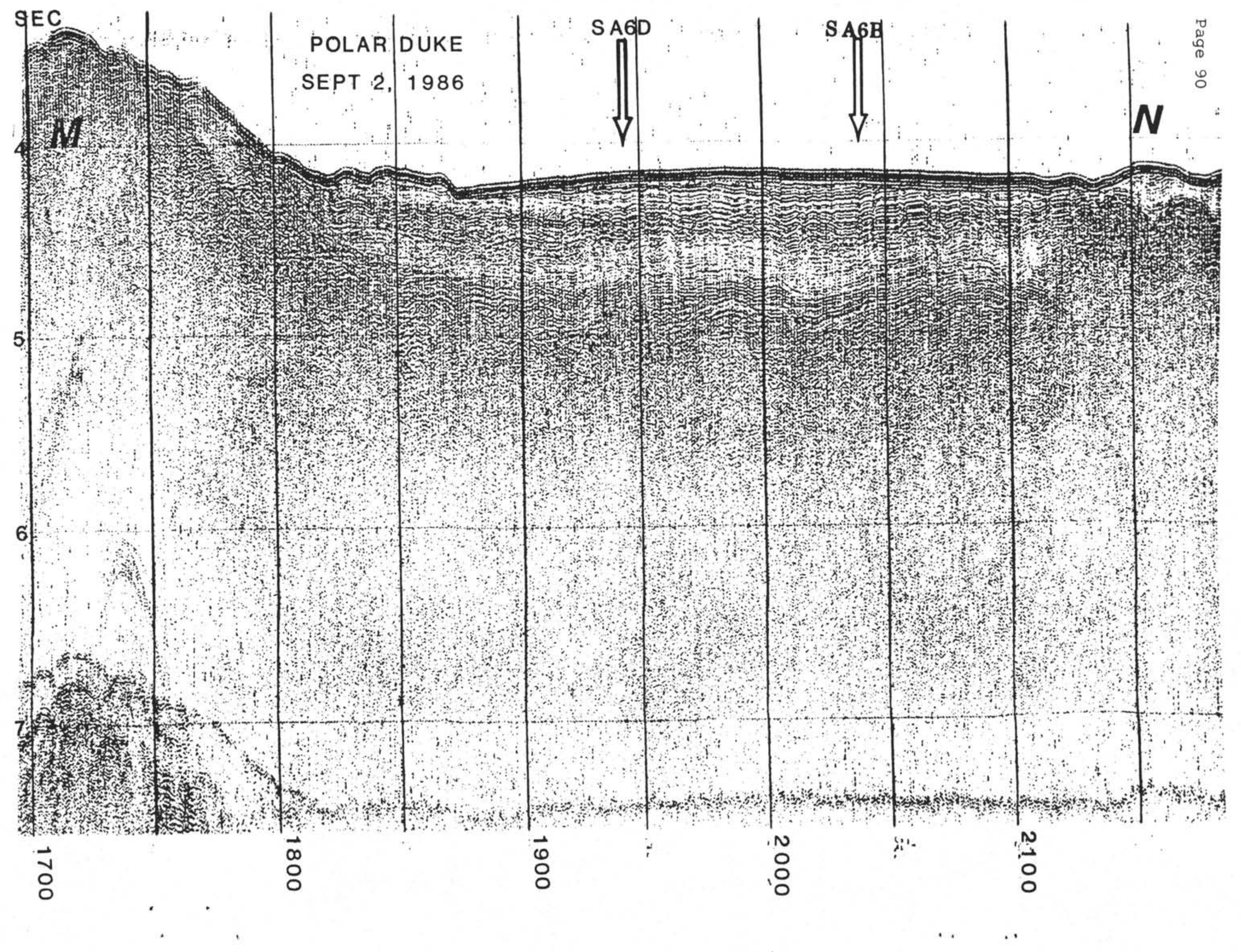




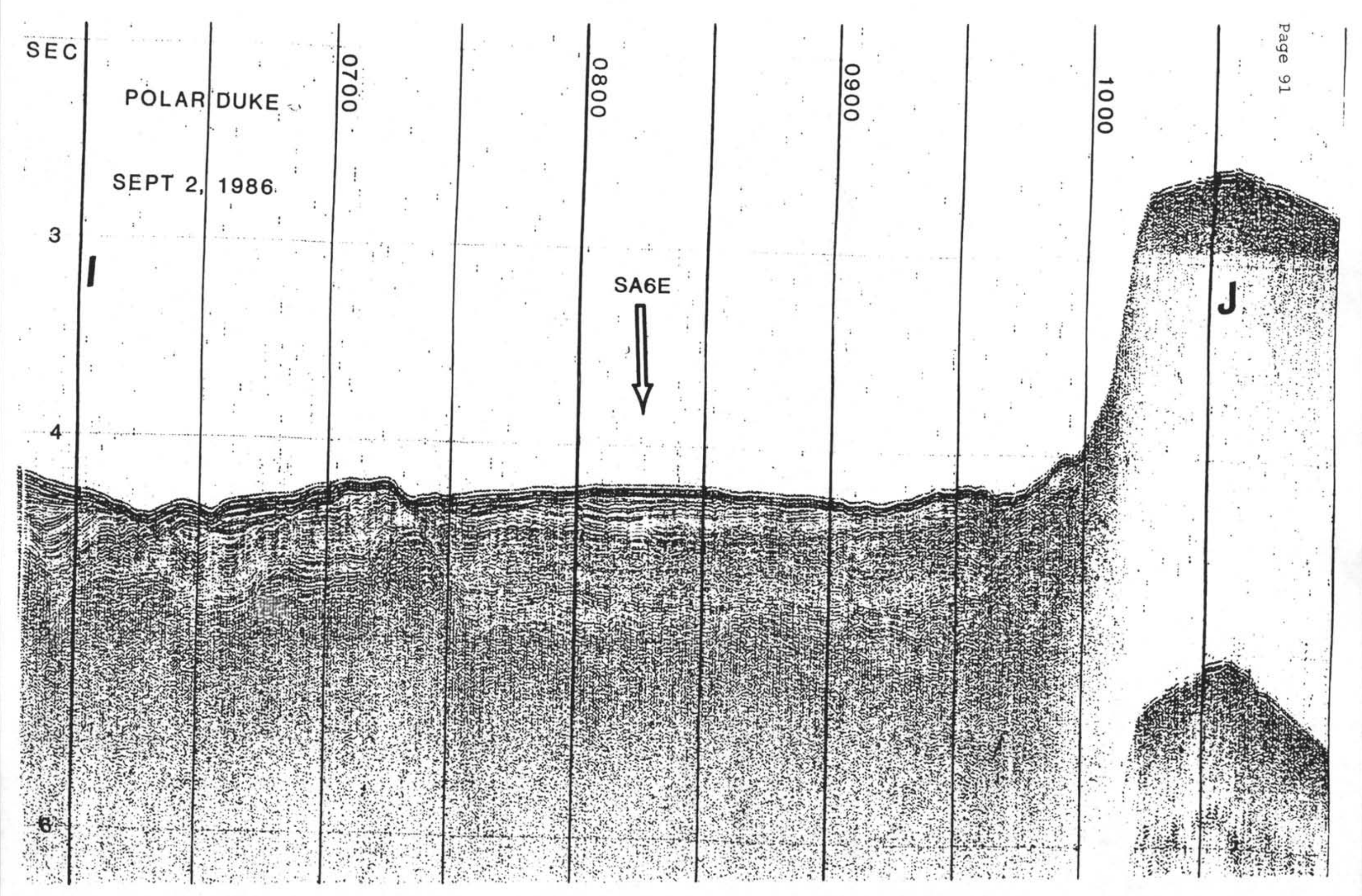


Page 92

SITE NUMBER: SA7A

POSITION: $47.185^{\circ} \mathrm{S}, 04.420^{\circ} \mathrm{E}$ SEDIMENT THICKNESS: $800 \mathrm{~m}$

WATER DEPTH: $4778 \mathrm{~m} \quad$ PRIORITY: II

PROPOSED DRILLING PROGRAM: Double APC, single XCB, approximate penetration $850 \mathrm{~m}$.

SEISMIC RECORD: R/V Conrad, 1010Z, 11/24/86

LOGGING: Standard Schlumberger logs, 2 runs, seismic stratigraphy tool and geochemical tool.

OBJECTIVES: Site SA7A lies west of the Meteor Rise on oceanic crust of age Chron-C20.6R created by the present mid-Atlantic Ridge which began separating the Islas Orcadas Rise and Meteor Rise by midale Paleocene. The major objective at this site is to obtain a sedimentary record of this important oceanic gateway between the South Atlantic and Southern Ocean. In conjunction with Sites SA2 and SA3, the record will be used to evaluate the history of increased deep water circulation through this gateway as a result of its growth and subsidence and the subsidence of the adjacent fracture zones and rises. A comparison of this site to Site SA3 will provide information on meridional environmental development. With Sites SA5, SA6, and SA8 the paleoenvironmental depth dependence can be investigated. Other objectives at this site include evaluation of:

-the vertical water mass gradients during the Paleogene (with shallow sites), -development of the ACC, -migration history of the Polar Front, -temporal variations in AABW flow.

Sites SA7 (A-E) provide various options in sampling sediments that appear between two seismically apparent unconformities. A preliminary interpretation is that the lower unconformity is a middle to late Eocene erosional event associated with the gateway opening. The upper unconformity is probably Miocene in age, probably associated with the Drake Passage opening • Note that Site SA3 also displays these two unconformities; however, the seismic expression of the lower sequence is not transparent as at Site SA3.

SEDIMENT TYPE: Diatomaceous ooze, calcareous/siliceous ooze and chalk, zeolitic clay (Eocene), basalt. 
Page 93

SITE NUMBER: SA7B

POSITION: $47.216^{\circ} \mathrm{S}, 04.864^{\circ} \mathrm{E} \quad$ SEDIMENT THICKNESS: $700 \mathrm{~m}$

WATER DEPTH: $4624 \mathrm{~m} \quad$ PRIORITY: II

PROPOSED DRILLING PROGRAM: Double APC, single XCB, approximate penetration $750 \mathrm{~m}$.

SEISMIC RECORD: R/V Conrad C2710, 2130Z, 11/24/86

LOGGING: Standard Schlumberger logs, 2 runs, seismic stratigraphy tool and geochemical tool.

OBJECTIVES: Site SA7B lies west of the Meteor Rise on Oceanic crust of age Chron-C21.2N created by the present mid-Atlantic Ridge which began separating the Islas Orcadas Rise and Meteor Rise by middle Paleocene. The major objective at this site is to obtain a sedimentary record of this important oceanic gateway between the South Atlantic and Southern Ocean. In conjunction with Sites SA2 and SA3, the record will be used to evaluate the history of increased deep water circulation through this gateway as a result of its growth and subsidence and the subsidence of the adjacent fracture zones and rises. A comparison of this site to Site SA3 will provide information on meridional environmental development. With Sites SA5, SA6, and SA 8 the paleoenvironmental depth dependence can be investigated. Other objectives at this site include evaluation of :

-the vertical water mass gradients during the Paleogene (with shallow sites), -development of the ACC, -migration history of the Polar Front, -temporal variations in AABW flow. Sites SA7 (A-E) provide various options in sampling sediments that appear between two seismically apparent unconformities. A preliminary interpretation is that the lower unconformity is a middle to late Eocene erosional event associated with the gateway opening. The upper unconformity is probably Miocene in age, probably associated with the Drake Passage opening. Note that Site SA3 also displays these two unconformities; however, the seismic expression of the lower sequence is not transparent as at Site SA3.

SEDIMENT TYPE: Diatomaceous ooze, calcareous/siliceous ooze and chalk, zeolitic clay (Eocene), basalt. 
SITE NUMBER: SA7C

POSITION: $47.234^{\circ} \mathrm{S}, 05.208^{\circ} \mathrm{E}$ SEDIMENT THICKNESS: $400 \mathrm{~m}$

WATER DEPTH: $4455 \mathrm{~m} \quad$ PRIORITY: II

PROPOSED DRILLING PROGRAM: Double APC, single XCB, approximate penetration $450 \mathrm{~m}$.

SEISMIC RECORD: R/V Conrad C2710, 0305Z, 11/23/86

LOGGING: Standard Schlumberger logs, 2 runs, seismic stratigraphy

tool and geochemical tool.

OBJECTIVES: Site SA7C lies west of the Meteor Rise on oceanic crust of age Chron-C21.5R created by the present mid-Atlantic Ridge which began separating the Islas Orcadas Rise and Meteor Rise by middle Paleocene. The major objective at this site is to obtain a sedimentary record of this important oceanic gateway between the South Atlantic and Southern Ocean. In conjunction with Sites SA2 and SA3, the record will be used to evaluate the history of increased deep water circulation through this gateway as a result of its growth and subsidence and the subsidence of the adjacent fracture zones and rises. A comparison of this site to Site SA 3 will provide information on meridional environmental development. With Sites SA5, SA6, and SA8 the paleoenvironmental depth dependence can be investigated. Other objectives at this site include evaluation of:

-the vertical water mass gradients during the Paleogene (with shallow sites), -development of the ACC, -migration history of the Polar Front, -temporal variations in AABW flow. Sites SA7 (A-E) provide various options in sampling sediments that appear between two seismically apparent unconformities. A preliminary interpretation is that the lower unconformity is a middle to late Eocene erosional event associated with the gateway opening. The upper unconformity is probably Miocene in age, probably associated with the Drake Passage opening. Note that Site SA3 also displays these two unconformities; however, the seismic expression of the lower sequence is not transparent as at Site SA3.

SEDIMENT TYPE: Diatomaceous ooze, calcareous/siliceous ooze and chalk, zeolitic clay (Eocene), basalt. 
SITE NUMBER: SATD

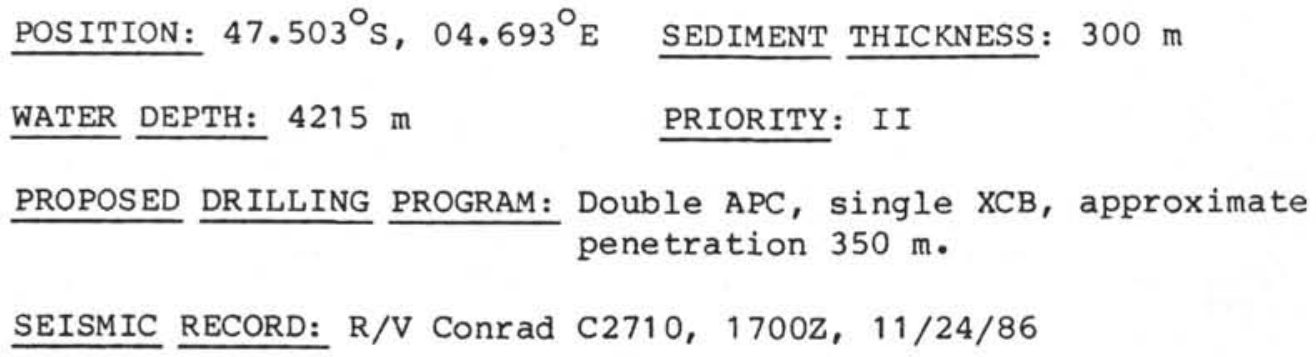

OBJECTIVES: Site SA7D lies west of the Meteor Rise on oceanic crust of age Chron-C20.8R created by the present mid-Atlantic Ridge which began separating the Islas Orcadas Rise and Meteor Rise by middle Paleocene. The major objective at this site is to obtain a sedimentary record of this important oceanic gateway between the South Atlantic and Southern Ocean. In conjunction with Sites SA2 and SA3, the record will be used to evaluate the history of increased deep water circulation through this gateway as a result of its growth and subsidence and the subsidence of the adjacent fracture zones and rises. A comparison of this site to Site SA3 will provide information on meridional environmental development. With Sites SA5, SA6, and SA8 the paleoenvironmental depth dependence can be investigated. Other objectives at this site include evaluation of:

-the vertical water mass gradients during the Paleogene (with shallow sites), -development of the ACC, -migration history of the Polar Front, -temporal variations in AABW flow. Sites SA7 ( $A-E$ ) provide various options in sampling sediments that appear between two seismically apparent unconformities. A preliminary interpretation is that the lower unconformity is a middle to late Eocene erosional event associated with the gateway opening. The upper unconformity is probably Miocene in age, probably associated with the Drake Passage opening. Note that Site SA3 also displays these two unconformities; however, the seismic expression of the lower sequence is not transparent as at Site SA3.

SEDIMENT TYPE: Diatomaceous ooze, calcareous/siliceous ooze and chalk, zeolitic clay (Eocene), basalt. 
Page 96

SITE NUMBER: SA7E

POSITION: $47.144^{\circ} \mathrm{S}, 05.692^{\circ} \mathrm{E} \quad$ SEDIMENT THICKNESS: $510 \mathrm{~m}$

WATER DEPTH: $4413 \mathrm{~m} \quad$ PRIORITY: II

PROPOSED DRILLING PROGRAM: Double APC, single XCB, approximate

penetration $560 \mathrm{~m}$.

SEISMIC RECORD: R/V Conrad C2710 0055Z, 11/23/86

LOGGING: Standare Schlumberger logs, 2 runs, seismic stratigraphy tool and geochemical tool.

OBJECTIVES: Site SA7E lies west of the Meteor Rise on oceanic crust of age Chron C23. ON created by the present mid-Atlantic Ridge which began separating the Islas Orcadas Rise and Meteor Rise by middle Paleocene. The major objective at this site is to obtain a sedimentary record of this important oceanic gateway between the South Atlantic and Southern Ocean. In conjunction with Sites SA2 and SA3, the record will be used to evaluate the history of increased deep water circulation through this gateway as a result of its growth and subsidence and the subsidence of the adjacent fracture zones and rises. A comparison of this site to Site SA3 will provide information on meridional environmental development. With Sites SA5, SA6, and SA8 the paleoenvironmental depth dependence can be investigated. Other objectives at this site include evaluation of :

-the vertical water mass gradients during the Paleogene (with shallow sites), -development of the ACC,

-migration history of the Polar Front, -temporal variations in AABW flow. Sites SA7 (A-E) provide various options in sampling sediments that appear between two seismically apparent unconformities. A preliminary interpretation is that the lower unconformity is a middle to late Eocene erosional event associated with the gateway opening. The upper unconformity is probably Miocene in age, probably associated with the Drake Passage opening . Note that Site SA3 also displays these two unconformities; however, the seismic expression of the lower sequence is not transparent as at Site SA3.

SEDIMENT TYPE: Diatomaceous ooze, calcareous/siliceous ooze and chalk, zeolitic clay (Eocene), basalt. 


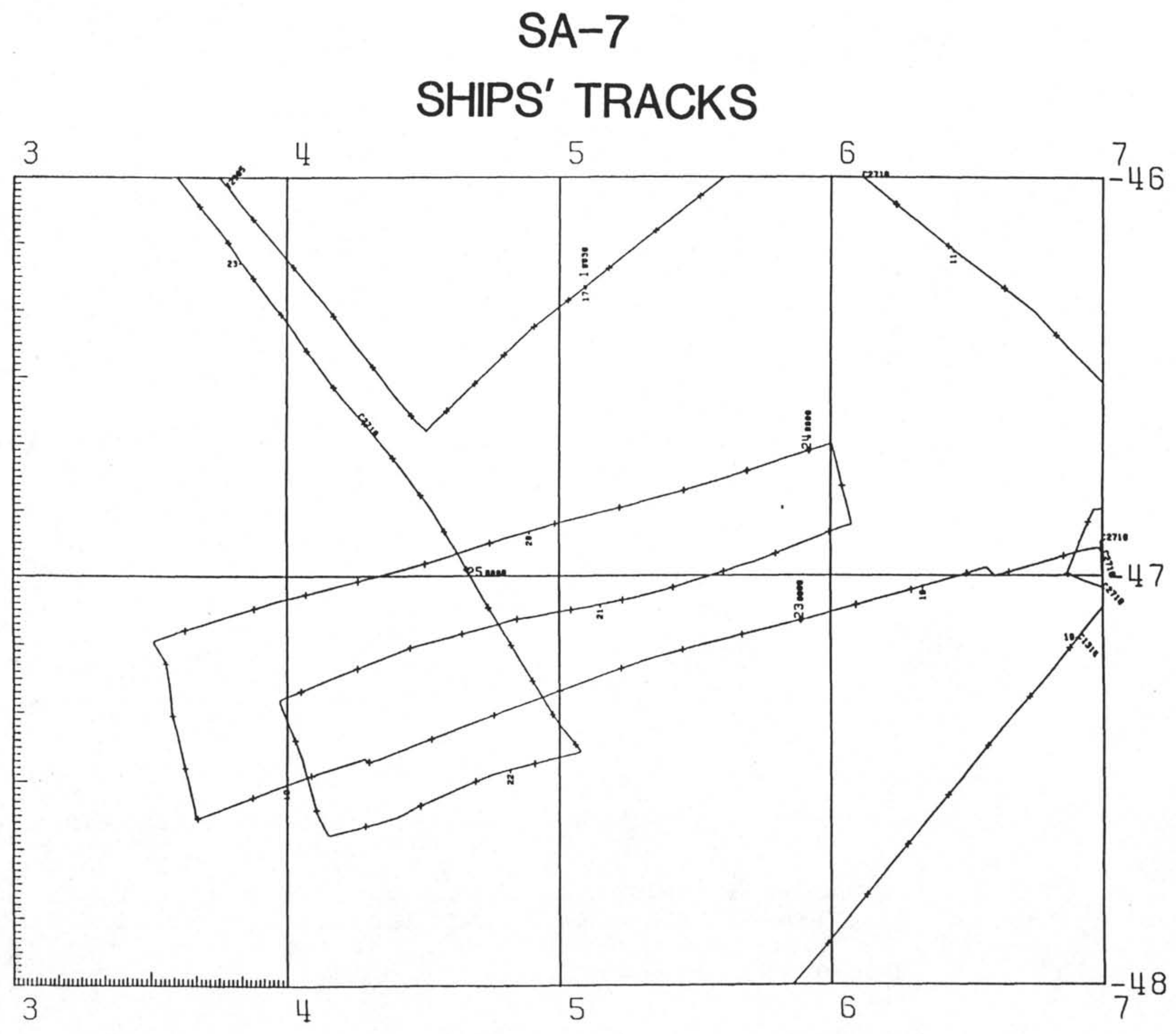


SA-7

GEBCO BATHYMETRY

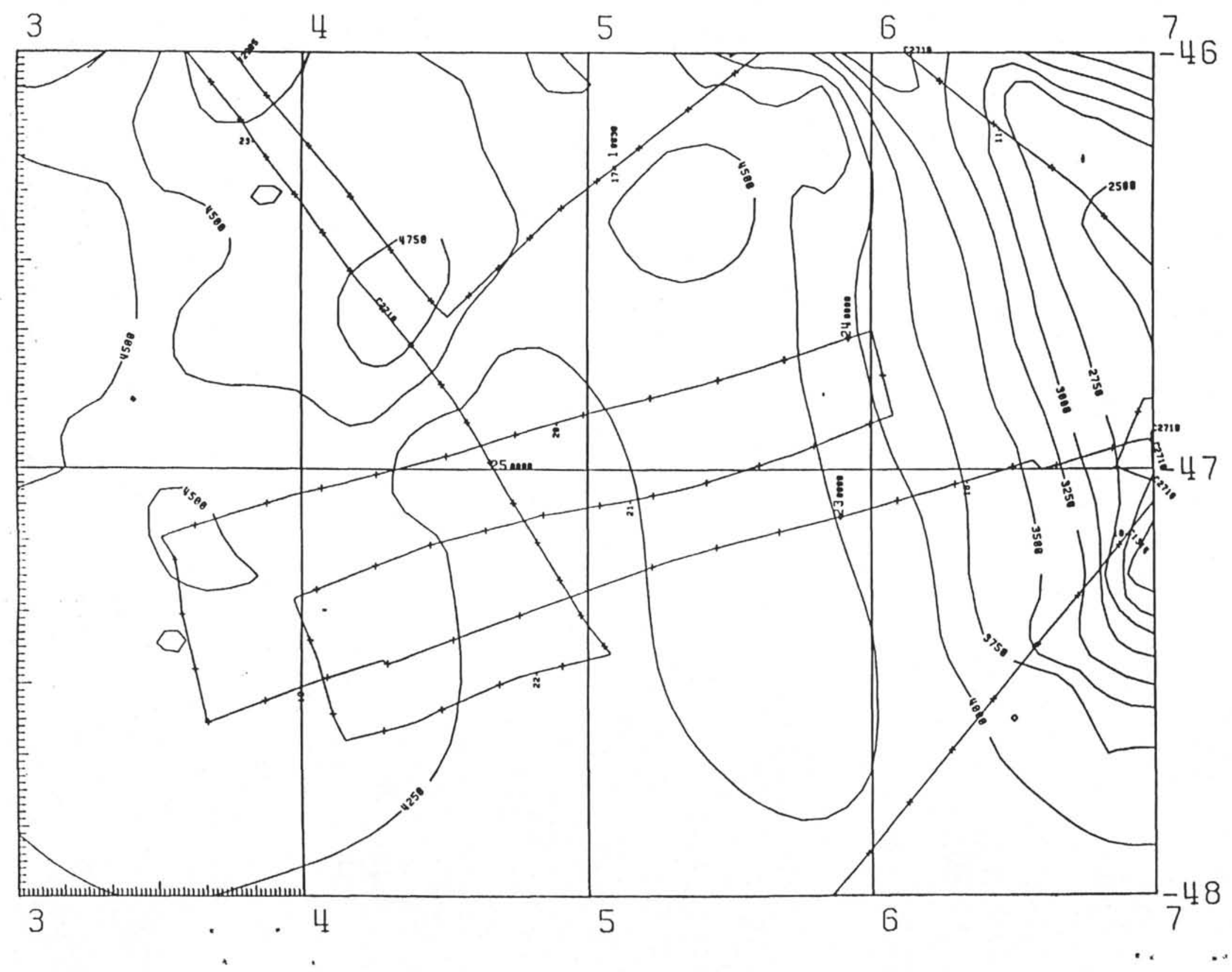




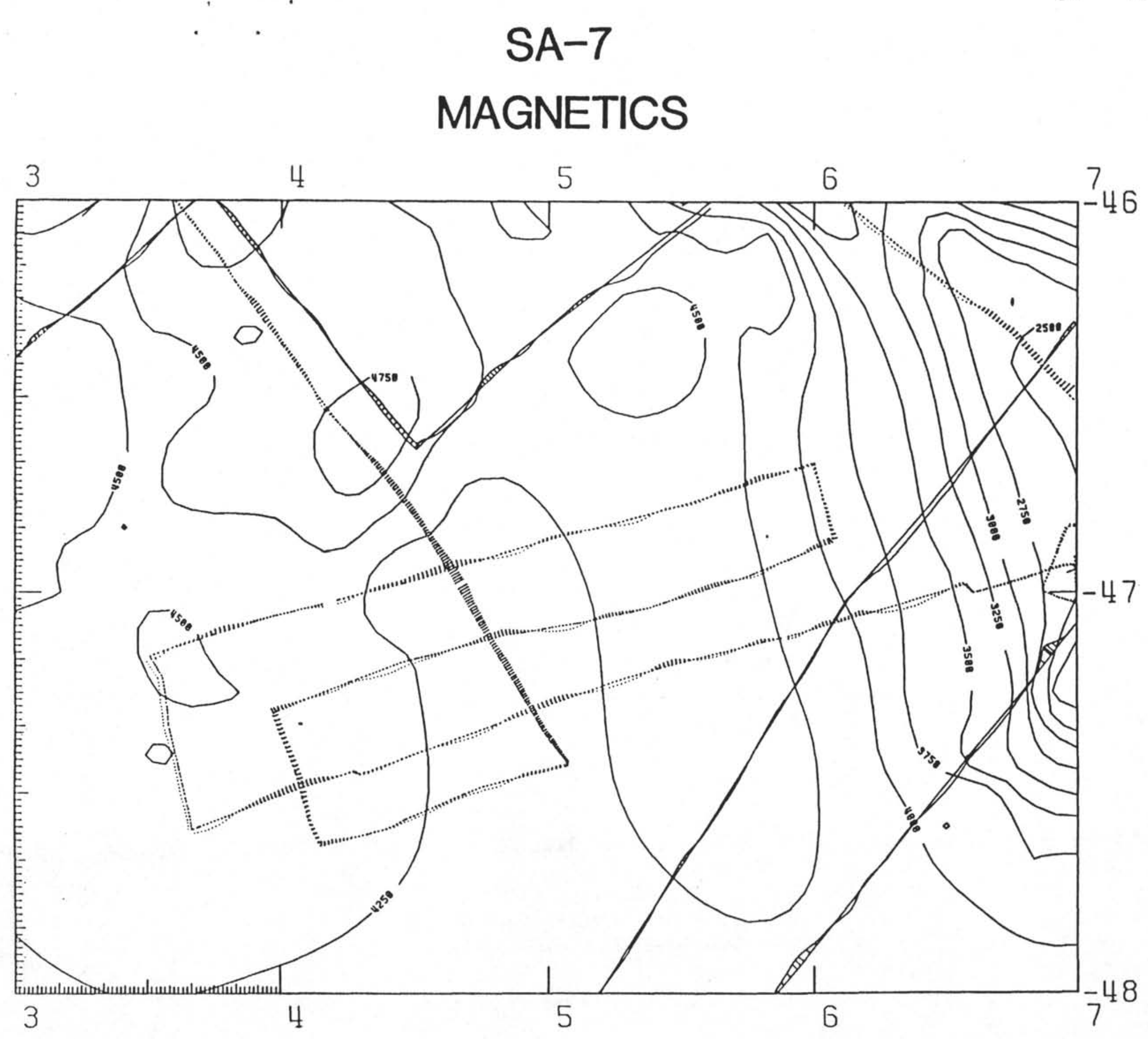




\section{$\mathrm{SA}-7$ \\ CORE LOCATION}

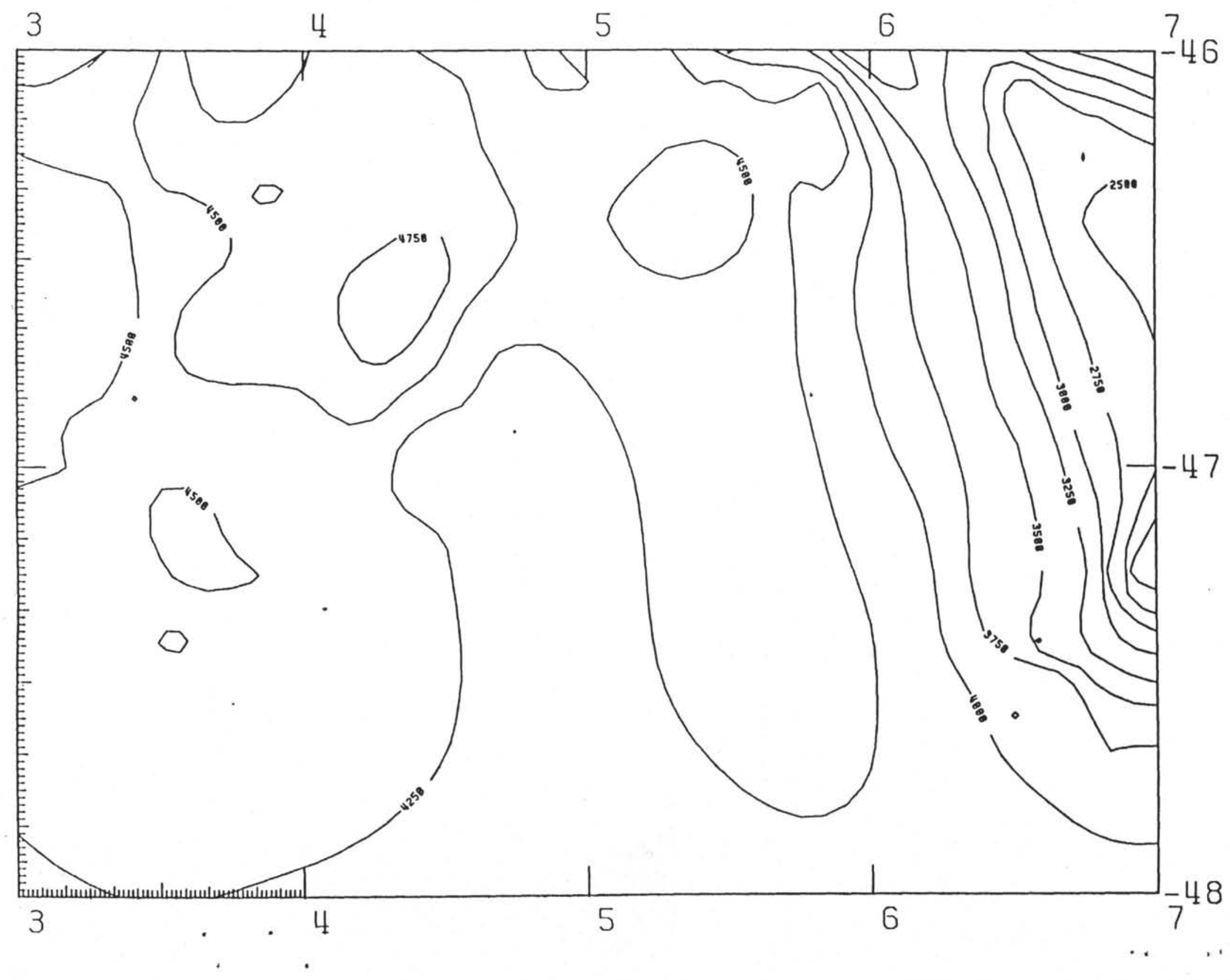




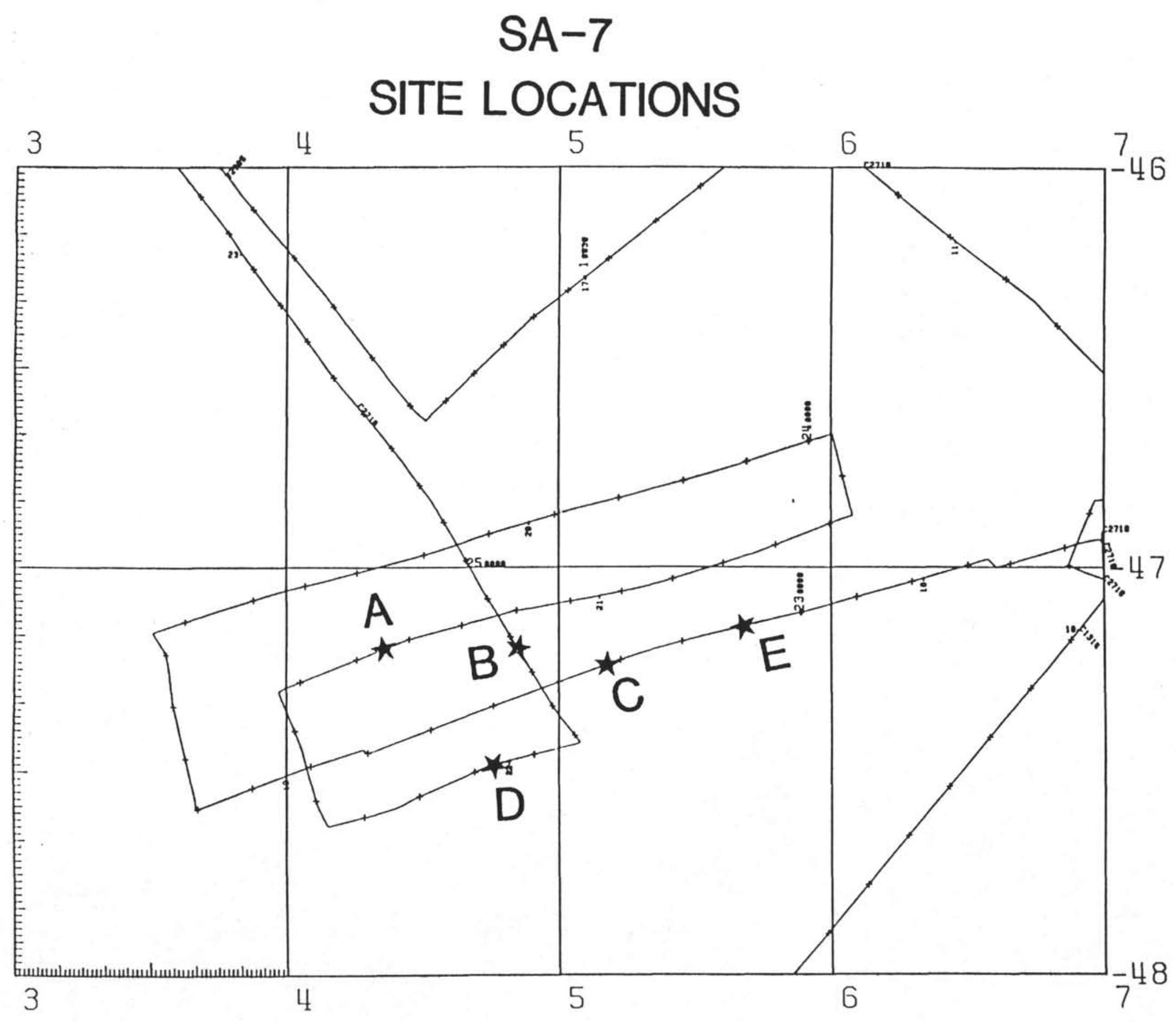


CONRAD $2710 \quad$ NOV.24, 1986

\section{SECS}

5

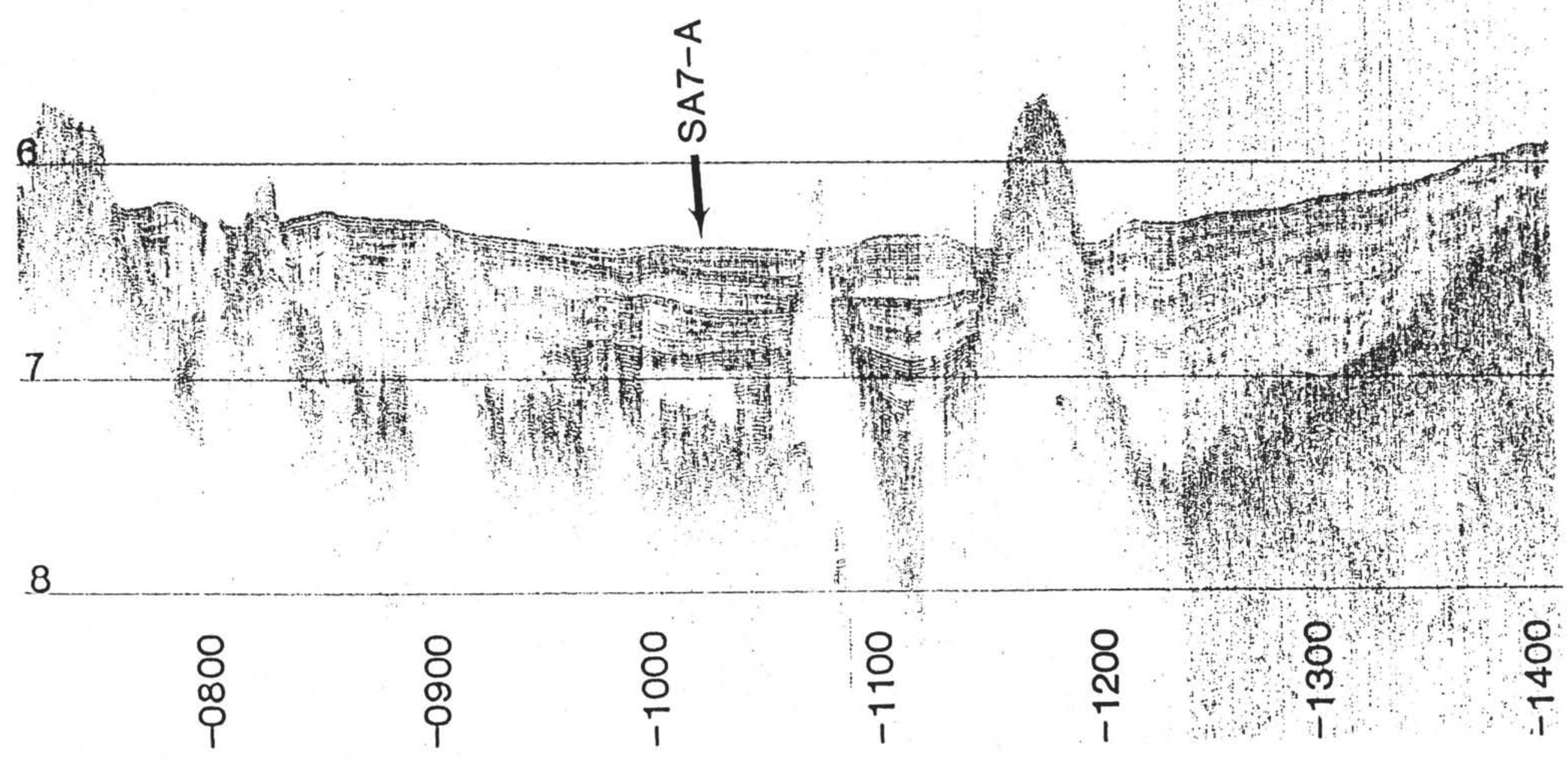


CONRAD 2710 NOV. 24, 1986

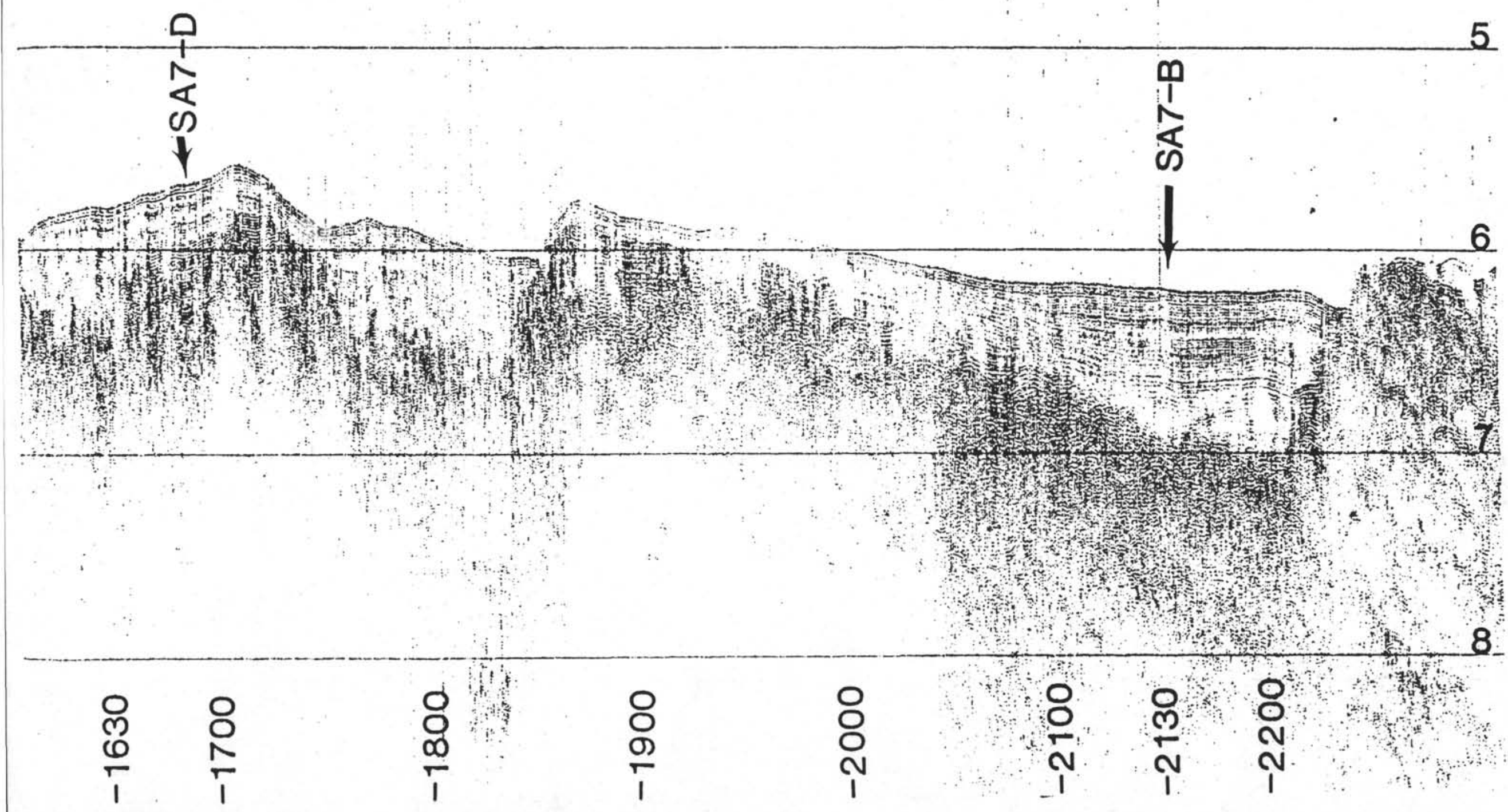


CONRAD 2710 NOV. 23,1986

\section{SECS}

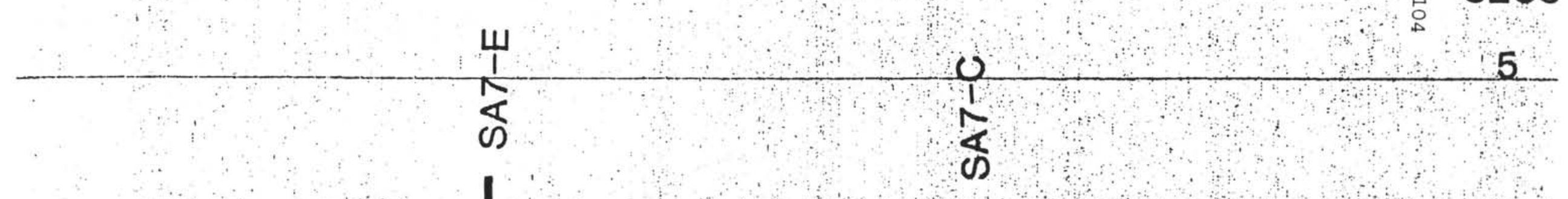

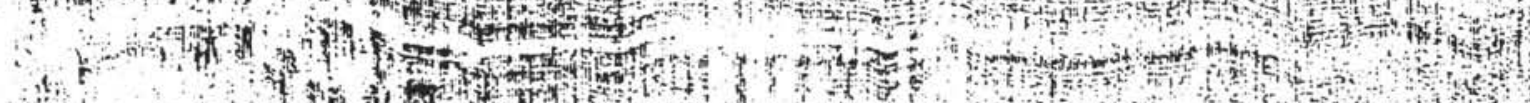

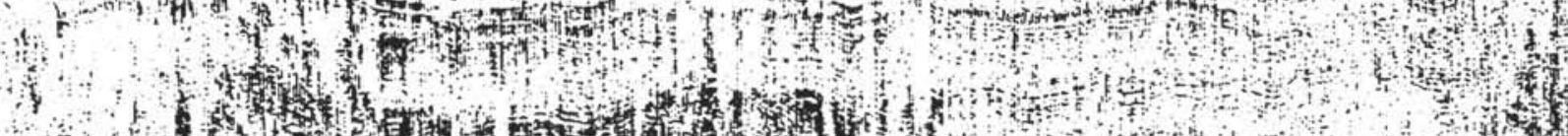

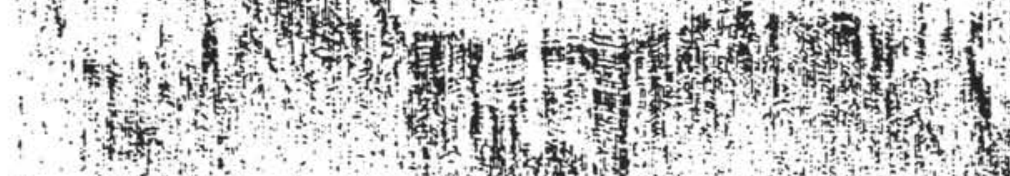

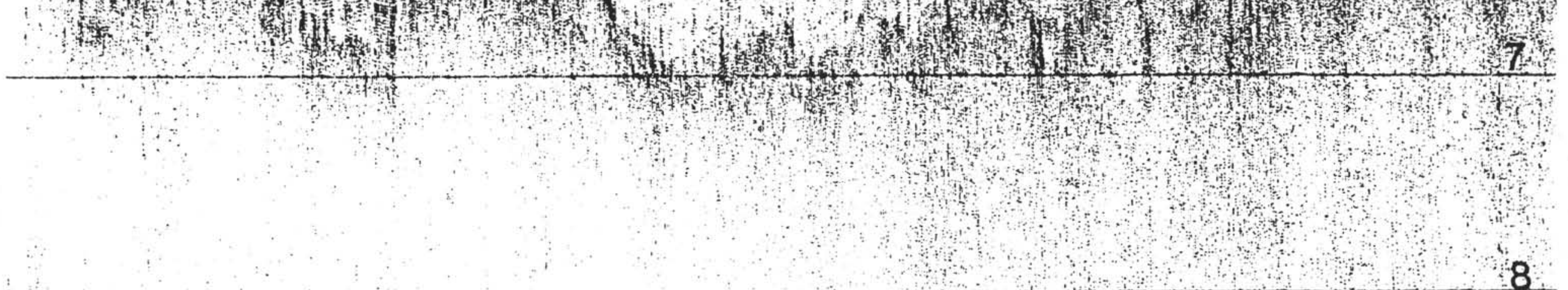

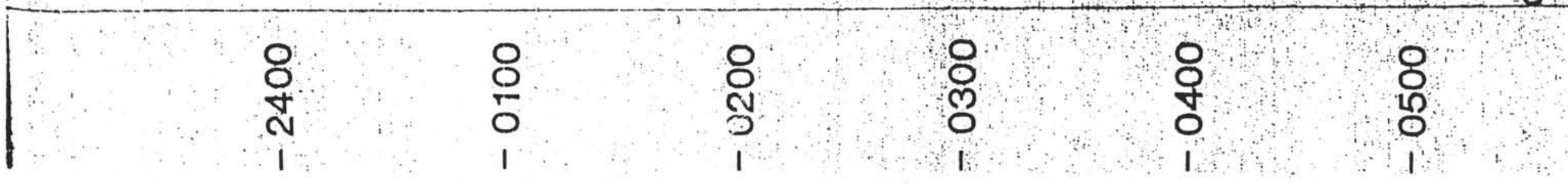




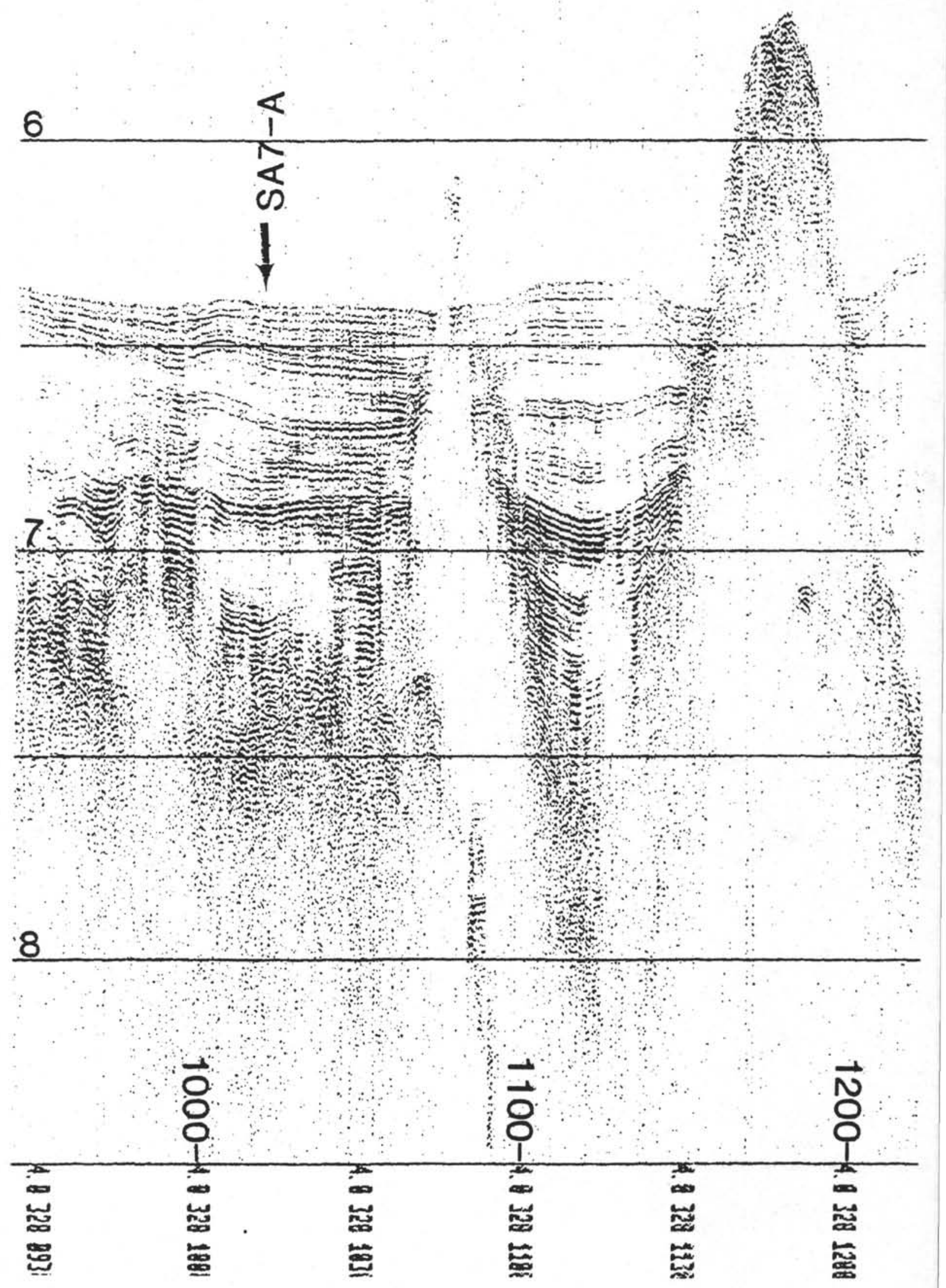


CONRAD $2710 \quad$ NOV.24,1986

\section{SECS}

5
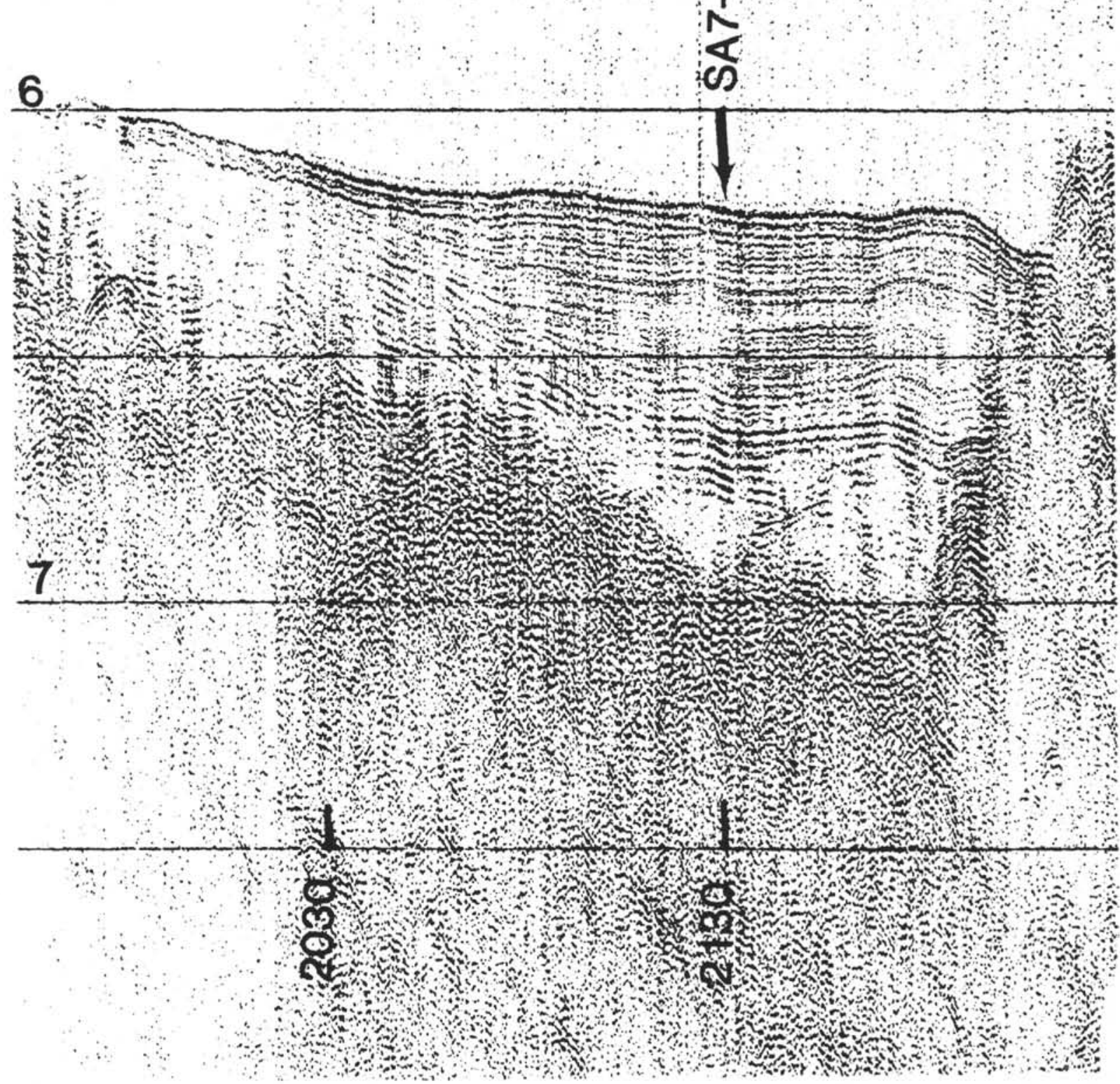
Page 107 CONRAD 2710 NOY 23,1984

SEC?

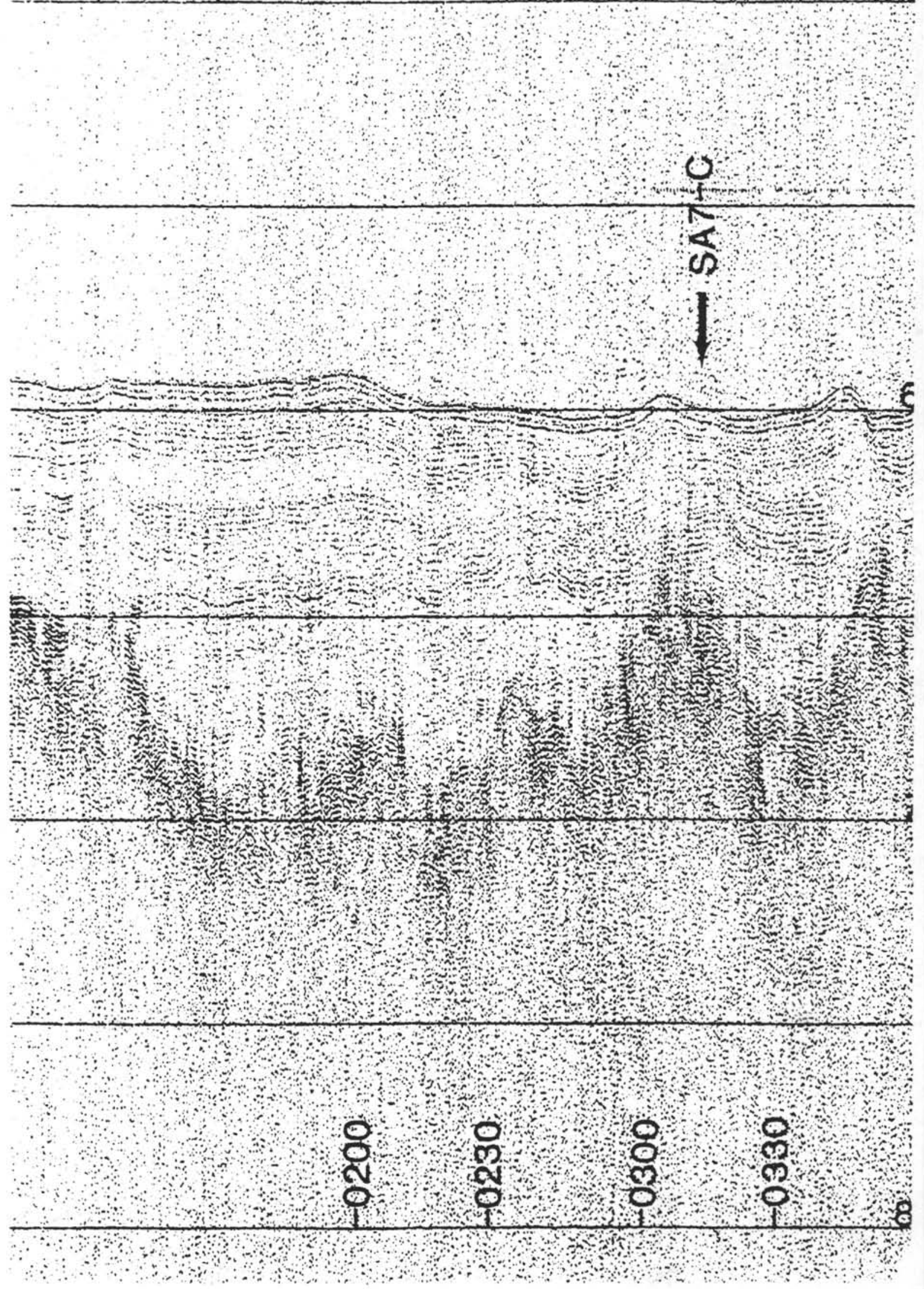




\section{CONRAD 2710 NOV. 24,1936 SECS}

5

SA7-D

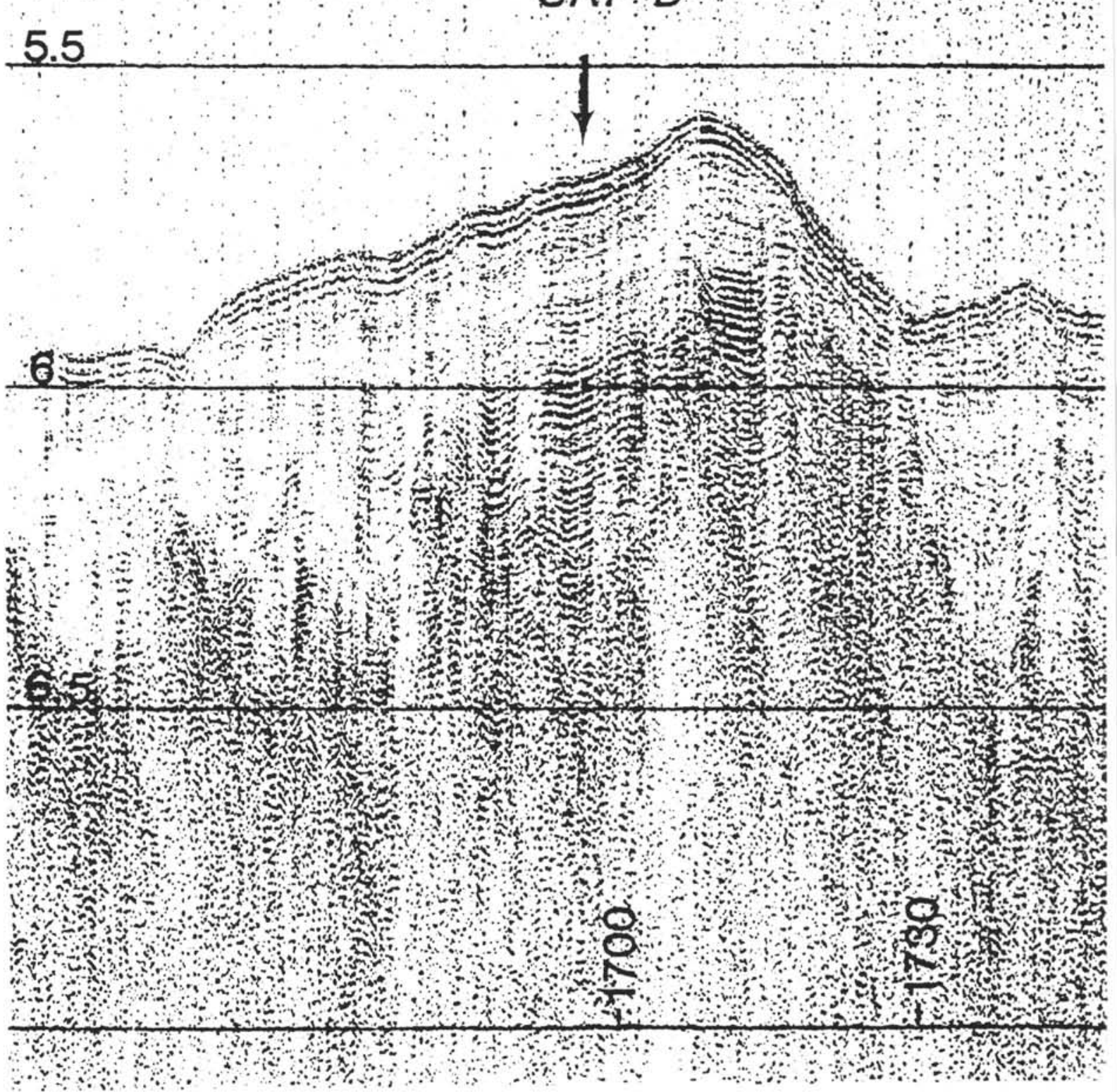


(a)

SEC

5.6

\section{CONRAD 27 10 NOV 231986}

6.0

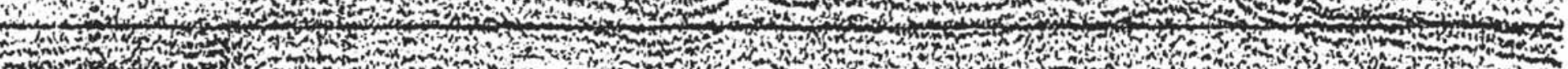

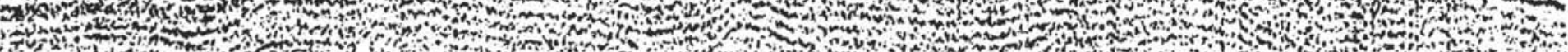

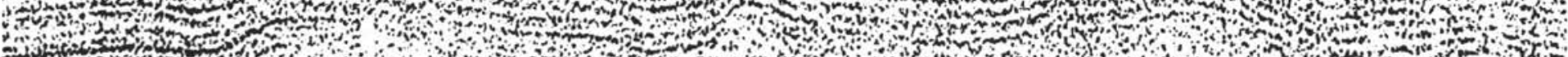
移

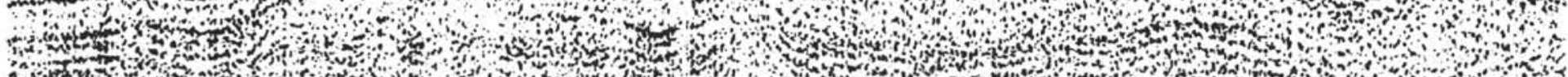
Aी

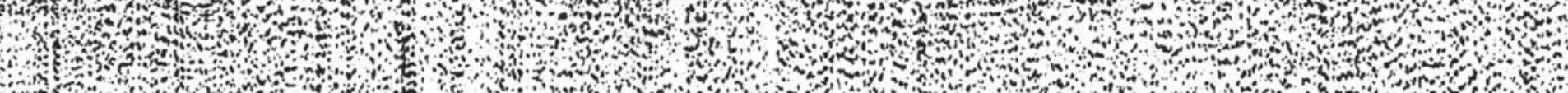

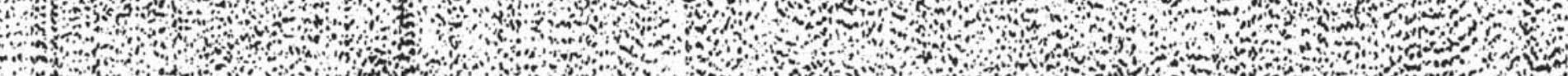

6.5

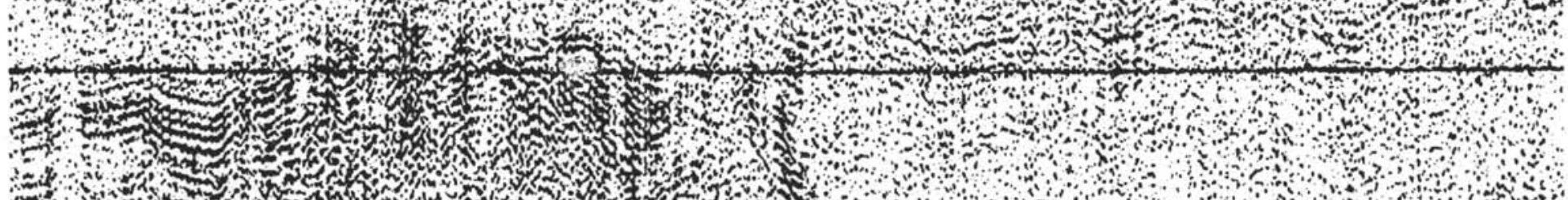

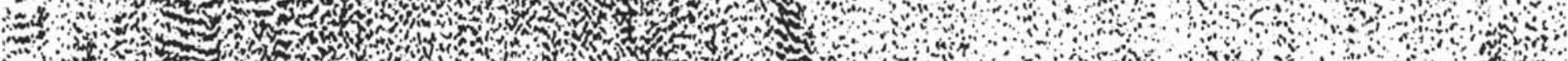

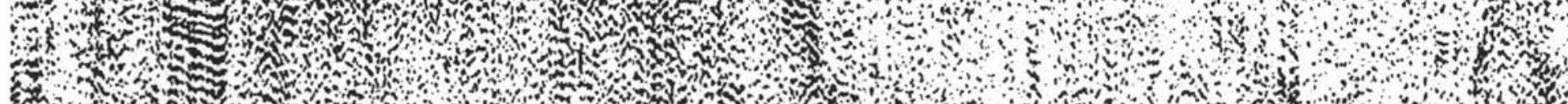

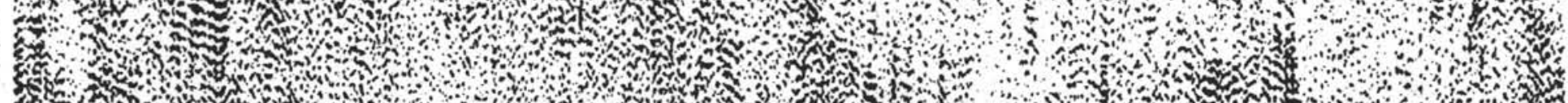

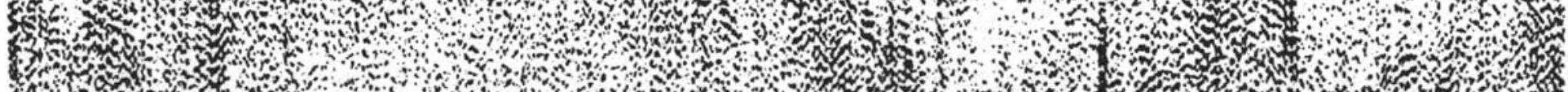

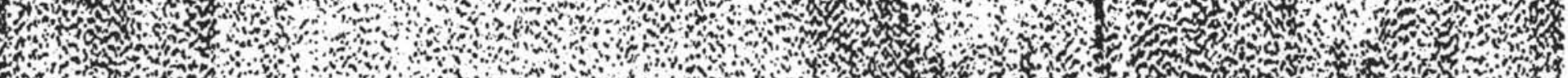

70 的

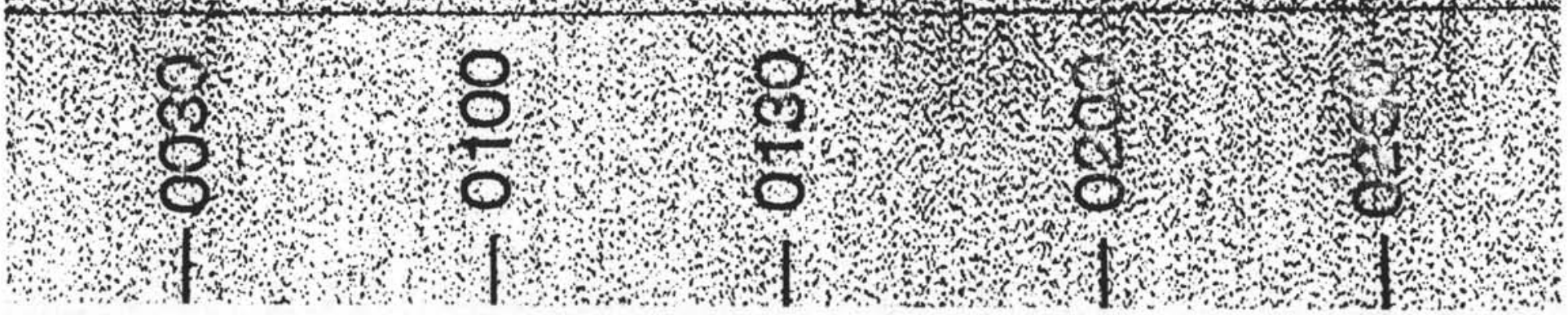


SITE NUMBER: SA

POSITION: $47.134^{\circ} \mathrm{S}, 07.517^{\circ} \mathrm{E}$ SEDIMENT THICKNESS: $850 \mathrm{~m}$

WATER DEPTH: $2328 \mathrm{~m} \quad$ PRIORITY: II

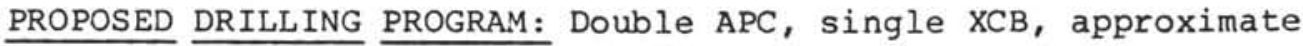
penetration $900 \mathrm{~m}$.

SEISMIC RECORD: R/V Conrad C2710 2055Z, 11/21/86

LOGGING: Standard Schlumberger logs, 2 runs, seismic stratigraphy tool and geochemical tool.

OBJECTIVES: Drilling of the broad and thick sedimentary sequence of the Meteor Rise has two main objectives: first, to determine the age, nature, and subsidence history of the Rise; and second, to interpret the influence of the shallow Paleogene Islas Orcadas Rise, Meteor Rise, and adjacent fracture zones on the oceanic communication between the Weddell-Scotia Sea and South Atlantic. Other specific objectives include:

-reconstruction of shallow to Circumpolar Deep Water (CPDW) structure,

-interpretation of Paleogene vertical water mass structure (with Sites SA2, SA3, SA5, SA6, SA7)

-documentation of the development of the ACC and Polar Front history, -examination of the geochemistry of aseismic ridges. Sites SA6 and SA 8 will provide meridional control on the development of the Cenozoic subantarctic paleoenvironment.

SEDIMENT TYPE: Paleogene-lower Neogene calcareous/siliceous oozes and chalk, pelagic clay (Eocene), basal sequence with shelf carbonates becoming interbedded with volcanic tephra and shallow submarine basalts. 
Page 111

SITE NUMBER: SA8B

POSITION: $47.079^{\circ} \mathrm{S}, 07.525^{\circ} \mathrm{E}$ SEDIMENT THICKNESS: $800 \mathrm{~m}$

WATER DEPTH: $2419 \mathrm{~m} \quad$ PRIORITY: II

PROPOSED DRILLING PROGRAM: Double APC, single XCB, approximate penetration $850 \mathrm{~m}$.

SEISMIC RECORD: R/V Conrad C2710 1655Z, 11/21/86

LOGGING: Standard Schlumberger logs, 2 runs, seismic stratigraphy tool and geochemical tool.

OBJECTIVES: Drilling of the broad and thick sedimentary sequence of the Meteor Rise has two main objectives: first, to determine the age, nature, and subsidence history of the Rise; and second, to interpret the influence of the shallow Paleogene Islas Orcadas Rise, Meteor Rise, and adjacent fracture zones on the oceanic communication between the Weddell-Scotia Sea and South Atlantic. Other specific objectives include: -reconstruction of shallow to Circumpolar Deep Water (CPDW) structure,

-interpretation of Paleogene vertical water mass structure (with Sites SA2, SA3, SA5, SA6, SA7)

-documentation of the development of the ACC and Polar Front history,

-examination of the geochemistry of aseismic ridges. Sites SA6 and SA8 will provide meridional control on the development of the Cenozoic subantarctic paleoenvironment.

SEDIMENT TYPE: Paleogene-lower Neogene calcareous/siliceous oozes and chalk, pelagic clay (Eocene), basal sequence with shelf carbonates becoming interbedded with volcanic tephra and shallow submarine basalts. 
SITE NUMBER: SA8C

POSITION: $46.992^{\circ} \mathrm{S}, 07.489^{\circ} \mathrm{E} \quad$ SEDIMENT THICKNESS: $750 \mathrm{~m}$

WATER DEPTH: $2510 \mathrm{~m} \quad$ PRIORITY: I

PROPOSED DRILLING PROGRAM: Double APC, single XCB, approximate penetration $800 \mathrm{~m}$.

SEISMIC RECORD: R/V Conrad C2710 0210Z, $11 / 22 / 86$

LOGGING: Standard Schlumberger logs, 2 runs, seismic stratigraphy tool and geochemical tool.

OBJECTIVES: Drilling of the broad and thick sedimentary sequence of the Meteor Rise has two main objectives: first, to determine the age, nature, and subsidence history of the Rise; and second, to interpret the influence of the shallow Paleogene Islas Orcadas Rise, Meteor Rise, and adjacent fracture zones on the oceanic communication between the Weddell-Scotia Sea and South Atlantic. Other specific objectives include: -reconstruction of shallow to Circumpolar Deep Water (CPDW) structure, -interpretation of Paleogene vertical water mass structure (with Sites SA2, SA3, SA5, SA6, SA7)

-documentation of the development of the ACC and Polar Front history,

-examination of the geochemistry of aseismic ridges. Sites SA6 and SA 8 will provide meridional control on the development of the Cenozoic subantarctic paleoenvironment.

SEDIMENT TYPE: Paleogene-lower Neogene calcareous/siliceous oozes and chalk, pelagic clay (Eocene), basal sequence with shelf carbonates becoming interbedded with volcanic tephra and shallow submarine basalts. 
Page 113

SITE NUMBER: SA8D

POSITION: $47.157^{\circ} \mathrm{S}, 07.506^{\circ} \mathrm{E}$ SEDIMENT THICKNESS: $800 \mathrm{~m}$

WATER DEPTH: $2290 \mathrm{~m} \quad$ PRIORITY: II

PROPOSED DRILLING PROGRAM: Double APC, single XCB, approximate penetration $850 \mathrm{~m}$.

SEISMIC RECORD: R/V Conrad C2710 1150Z, 11/20/86

LOGGING: Standard Schlumberger logs, 2 runs, seismic stratigraphy

tool and geochemical tool.

OBJECTIVES: Drilling of the broad and thick sedimentary sequence of the Meteor Rise has two main objectives: first, to determine the age, nature, and subsidence history of the Rise; and second, to interpret the influence of the shallow Paleogene Islas Orcadas Rise, Meteor Rise, and adjacent fracture zones on the oceanic communication between the Weddell-Scotia Sea and South Atlantic. Other specific objectives include:

-reconstruction of shallow to Circumpolar Deep Water (CPDW) structure,

-interpretation of Paleogene vertical water mass structure (with Sites SA2, SA3, SA5, SA6, SA7)

-documentation of the development of the ACC and Polar Front history,

-examination of the geochemistry of aseismic ridges.

Sites SA6 and SA 8 will provide meridional control on the development of the Cenozoic subantarctic paleoenvironment.

SEDIMENT TYPE: Paleogene-lower Neogene calcareous/siliceous oozes and chalk, pelagic clay (Eocene), basal sequence with shelf carbonates becoming interbedded with volcanic tephra and shallow submarine basalts. 
SITE NUMBER: SA8E

POSITION: $46.91^{\circ} \mathrm{S}, 07.325^{\circ} \mathrm{E}$ SEDIMENT THICKNESS: $250-800 \mathrm{~m}$

WATER DEPTH: $2540 \mathrm{~m} \quad$ PRIORITY: I

PROPOSED DRILLING PROGRAM: Double APC, single XCB, approximate penetration $850 \mathrm{~m}$.

Option requested to select site profile.

SEISMIC RECORD: R/V Conrad C2710 0510-0550Z, 11/21/86

LOGGING: Standard Schlumberger logs, 2 runs, seismic stratigraphy tool and geochemical tool.

OBJECTIVES: Drilling of the broad and thick sedimentary sequence of the Meteor Rise has two main objectives: first, to determine the age, nature, and subsidence history of the Rise; and second, to interpret the influence of the shallow Paleogene Islas Orcadas Rise, Meteor Rise, and adjacent fracture zones on the oceanic communication between the Weddell-Scotia Sea and South Atlantic. Other specific objectives include:

-reconstruction of shallow to Circumpolar Deep Water (CPDW) structure,

-interpretation of Paleogene vertical water mass structure (with Sites SA2, SA3, SA5, SA6, SA7)

-documentation of the development of the ACC and Polar Front history,

-examination of the geochemistry of aseismic ridges. Sites SA6 and SA 8 will provide meridional control on the development of the Cenozoic subantarctic paleoenvironment.

SEDIMENT TYPE: Paleogene-lower Neogene calcareous/siliceous oozes and chalk, pelagic clay (Eocene), basal sequence with shelf carbonates becoming interbedded with volcanic tephra and shallow submarine basalts. 
Page 115

SITE NUMBER: SA8F

POSITION: $47.04^{\circ} \mathrm{S}, \quad 08.018^{\circ} \mathrm{E}$ SEDIMENT THICKNESS: $250-800 \mathrm{~m}$

WATER DEPTH: $1700 \mathrm{~m} \quad$ PRIORITY: I

PROPOSED DRILLING PROGRAM: Double APC, single XCB, approximate penetration $850 \mathrm{~m}$.

Option requested to select site along profile.

SEISMIC RECORD: R/V Conrad C2710 2330-2350Z, 11/21/86

LOGGING: Standard Schlumberger logs, 2 runs, seismic stratigraphy

tool and geochemical tool.

OBJECTIVES: Drilling of the broad and thick sedimentary sequence of the Meteor Rise has two main objectives: first, to determine the age, nature, and subsidence history of the Rise; and second, to interpret the influence of the shallow Paleogene Islas Orcadas Rise, Meteor Rise, and adjacent fracture zones on the oceanic communication between the Weddell-Scotia Sea and South Atlantic. Other specific objectives include:

-reconstruction of shallow to Circumpolar Deep Water (CPDW) structure,

-interpretation of Paleogene vertical water mass structure (with Sites SA2, SA3, SA5, SA6, SA7)

-documentation of the development of the ACC and Polar Front history,

-examination of the geochemistry of aseismic ridges.

Sites SA6 and SA 8 will provide meridional control on the development of the Cenozoic subantarctic paleoenvironment.

SEDIMENT TYPE: Paleogene-lower Neogene calcareous/siliceous oozes and chalk, pelagic clay (Eocene), basal sequence with shelf carbonates becoming interbedded with volcanic tephra and shallow submarine basalts. 
Page 116

SITE NUMBER: SA8G

POSITION: $46.948^{\circ} \mathrm{S}, \quad 07.300^{\circ} \mathrm{E}$ SEDIMENT THICKNESS: $300-800 \mathrm{~m}$

WATER DEPTH: $2580 \mathrm{~m} \quad$ PRIORITY: I

PROPOSED DRILLING PROGRAM: Double APC, single XCB, approximate penetration $850 \mathrm{~m}$.

Option requested to select site along profile.

SEISMIC RECORD: R/V Conrad C2710 1615-1650Z, 11/22/86

LOGGING: Standard Schlumberger logs, 2 runs, seismic stratigraphy tool and geochemical tool.

OBJECTIVES: Drilling of the broad and thick sedimentary sequence of the Meteor Rise has two main objectives: first, to determine the age, nature, and subsidence history of the Rise; and second, to interpret the influence of the shallow Paleogene Islas Orcadas Rise, Meteor Rise, and adjacent fracture zones on the oceanic communication between the Weddell-Scotia Sea and South Atlantic. Other specific objectives include:

-reconstruction of shallow to Circumpolar Deep Water (CPDW) structure,

-interpretation of Paleogene vertical water mass structure (with Sites SA2, SA3, SA5, SA6, SA7)

-documentation of the development of the ACC and Polar Front history,

-examination of the geochemistry of aseismic ridges.

Sites SA6 and SA8 will provide meridional control on the development of the Cenozoic subantarctic paleoenvironment.

SEDIMENT TYPE: Paleogene-lower Neogene calcareous/siliceous oozes and chalk, pelagic clay (Eocene), basal sequence with shelf carbonates becoming interbedded with volcanic tephra and shallow submarine basalts. 


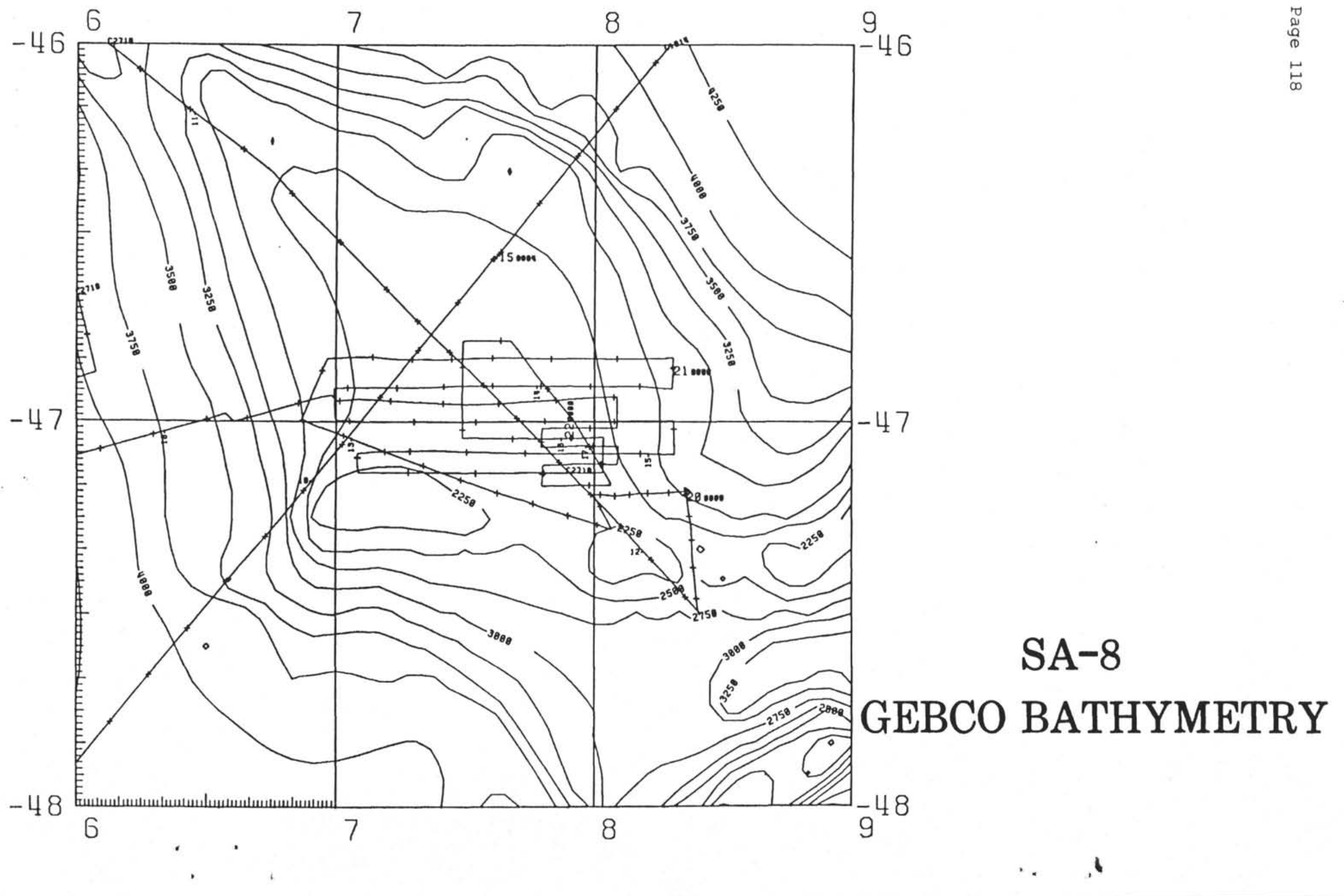




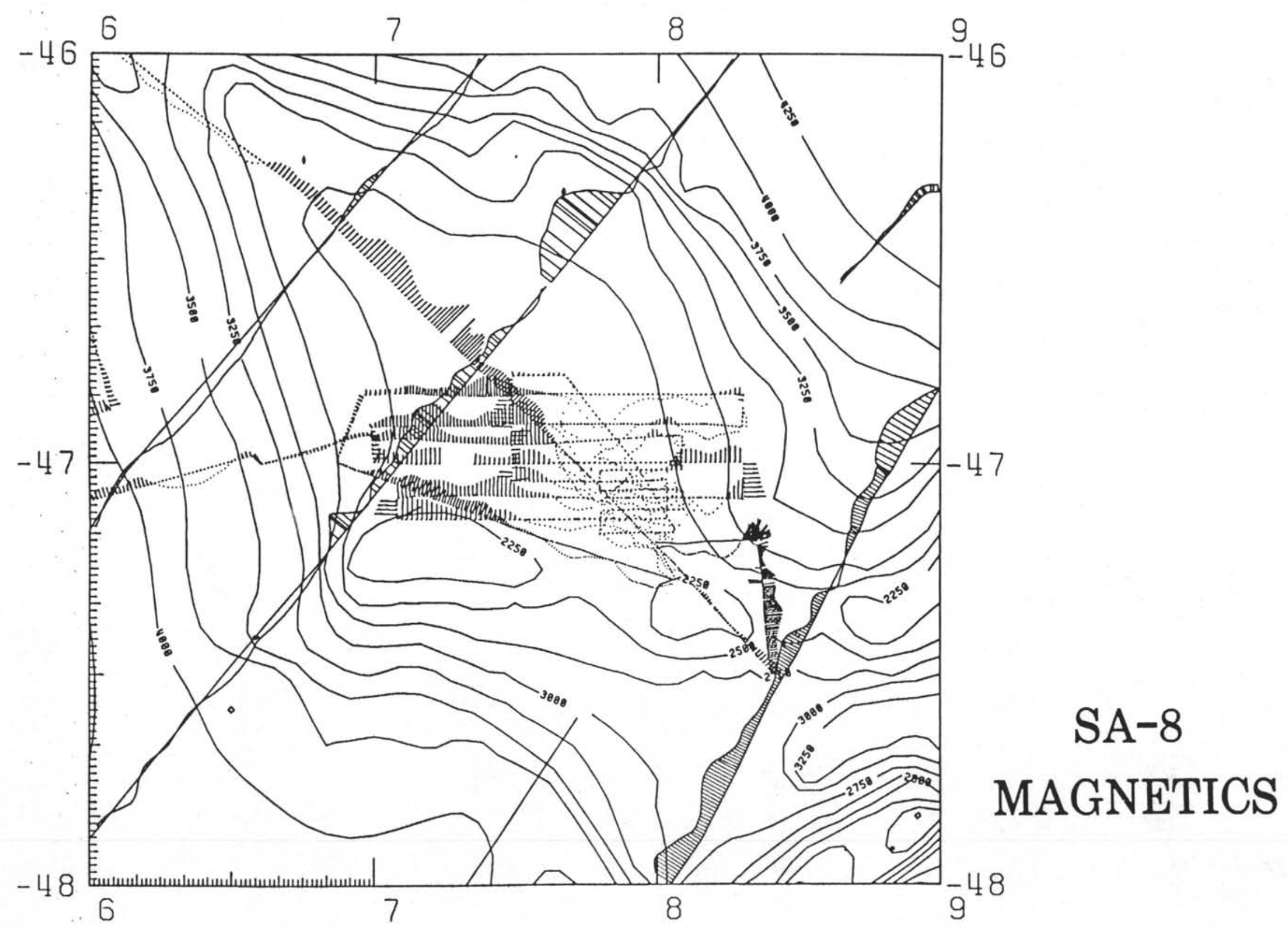




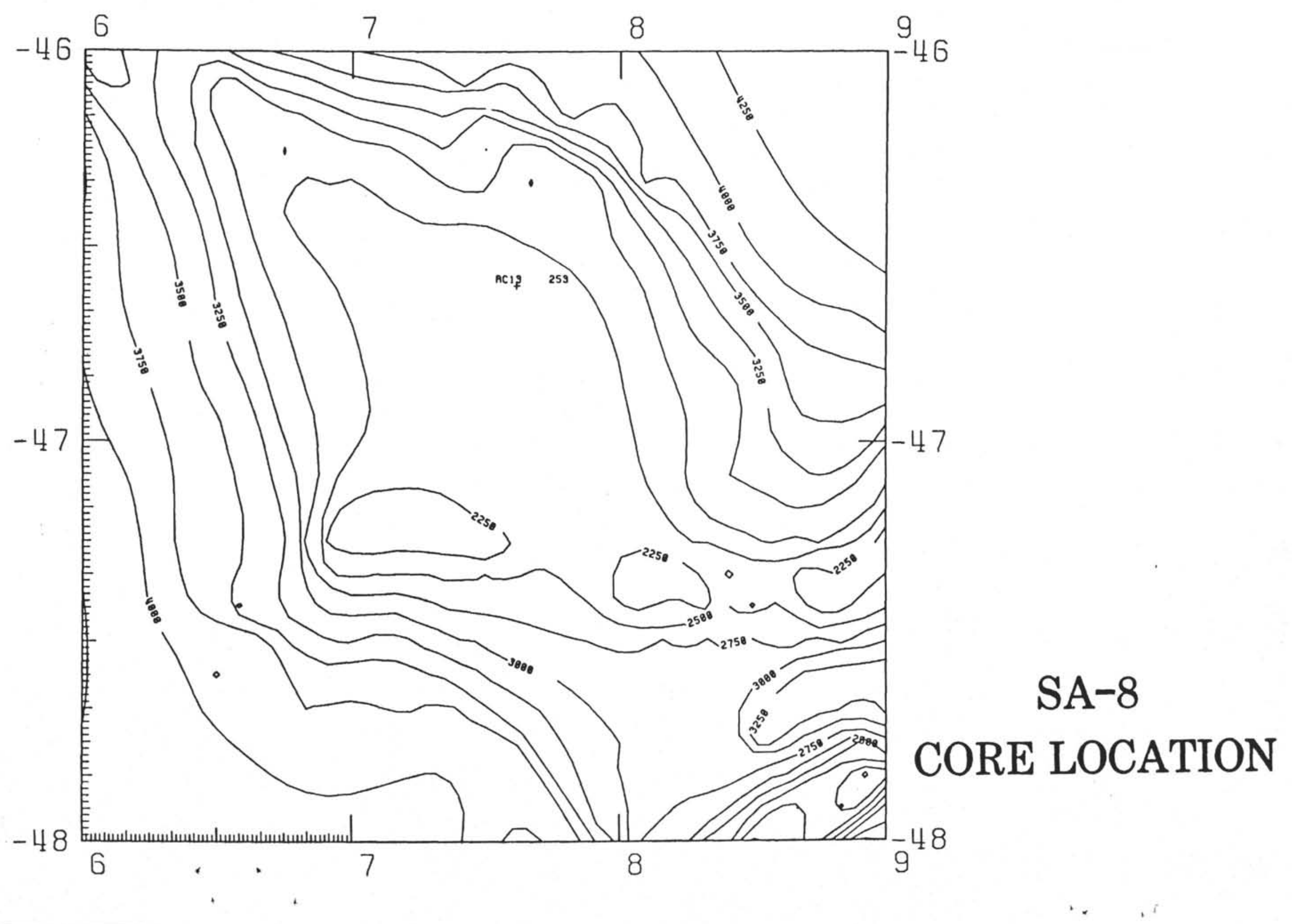




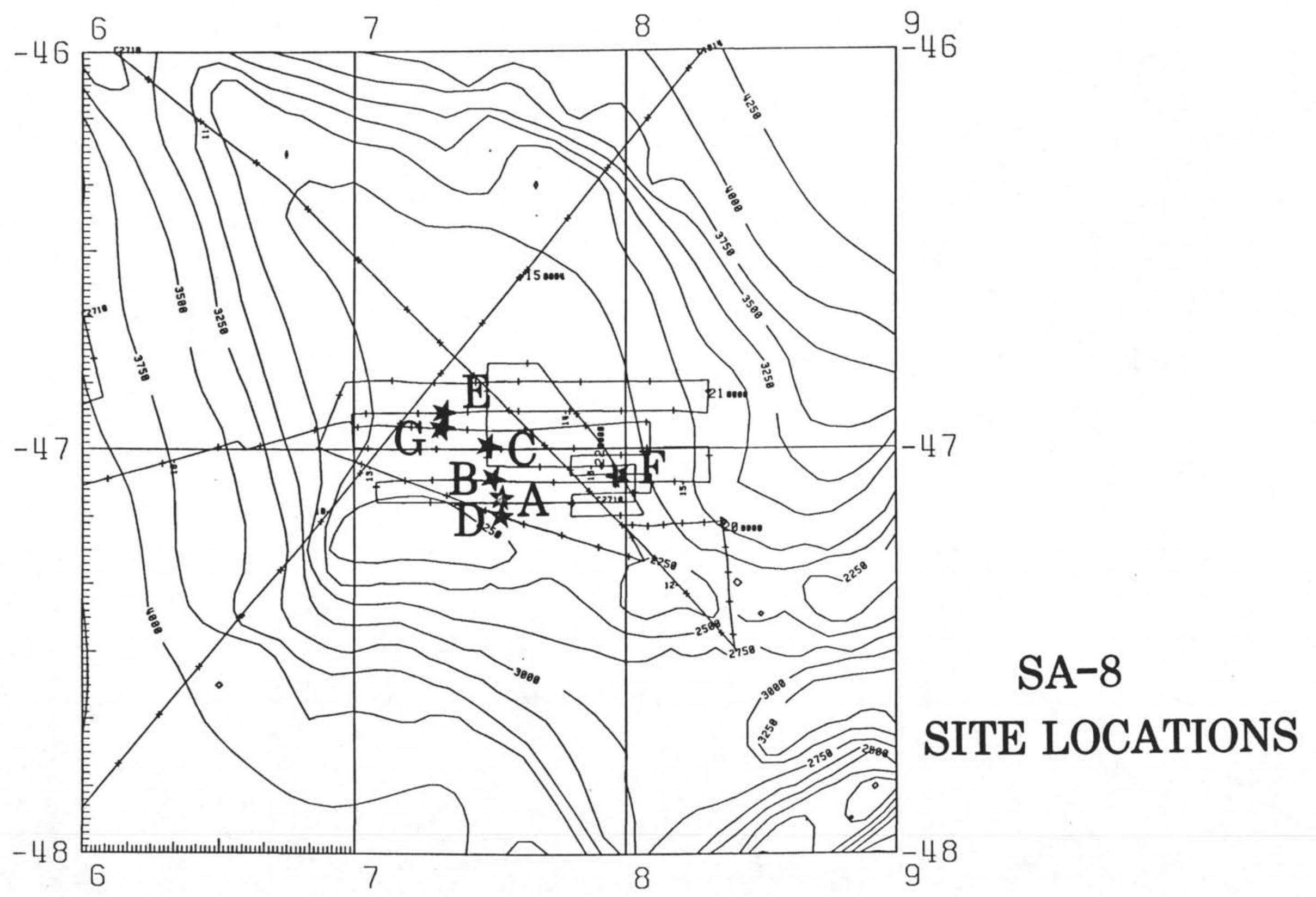




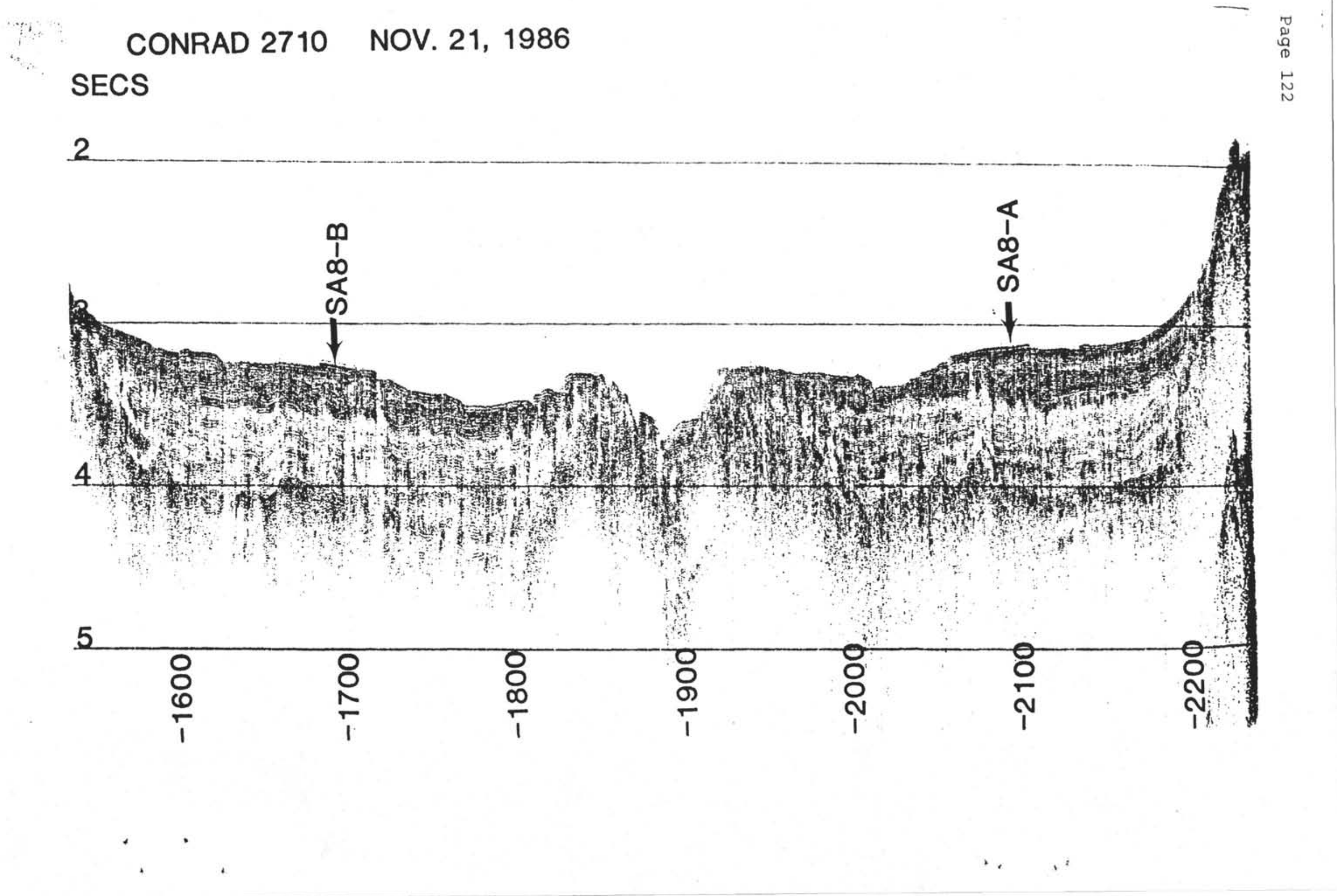




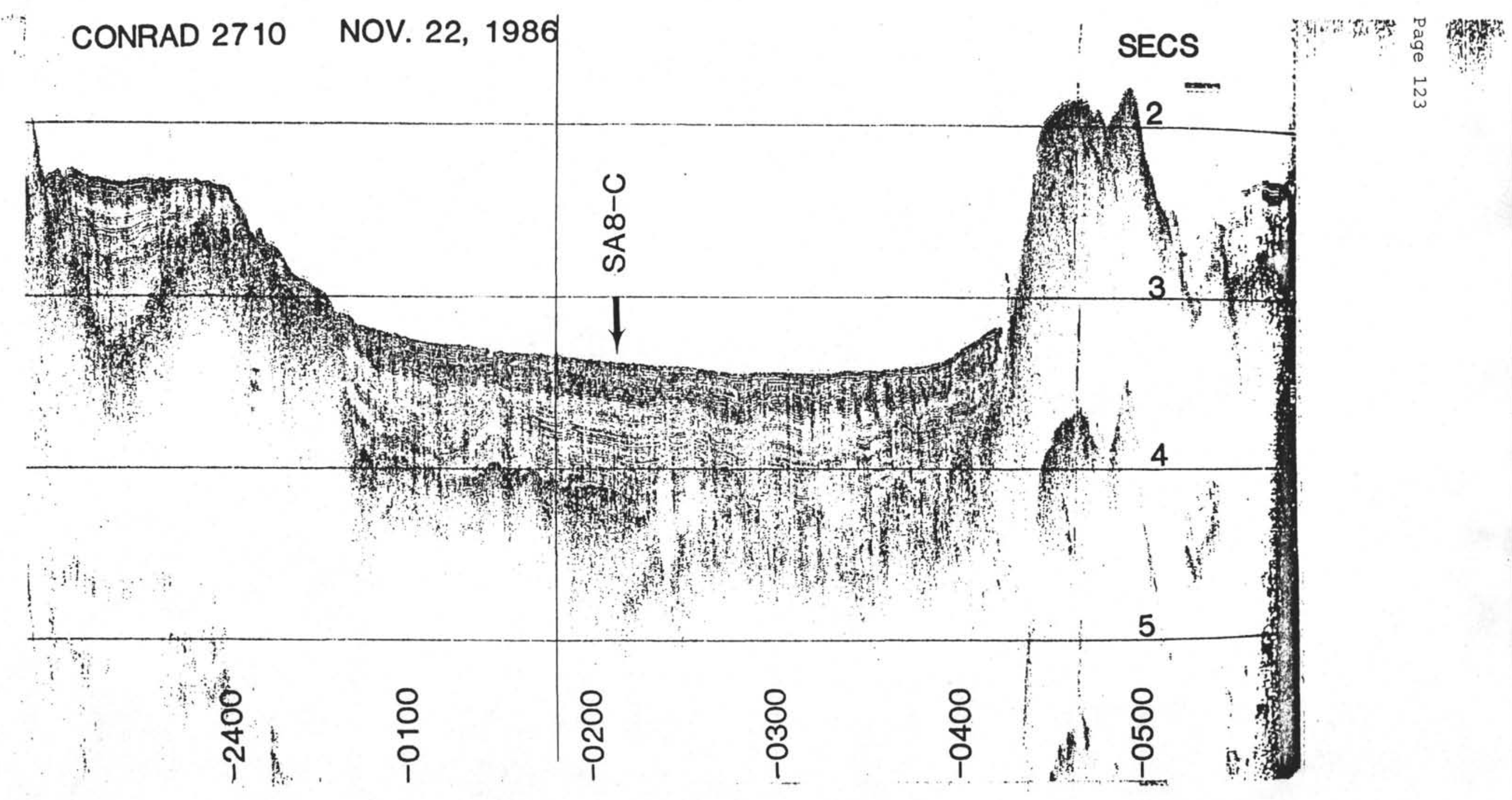




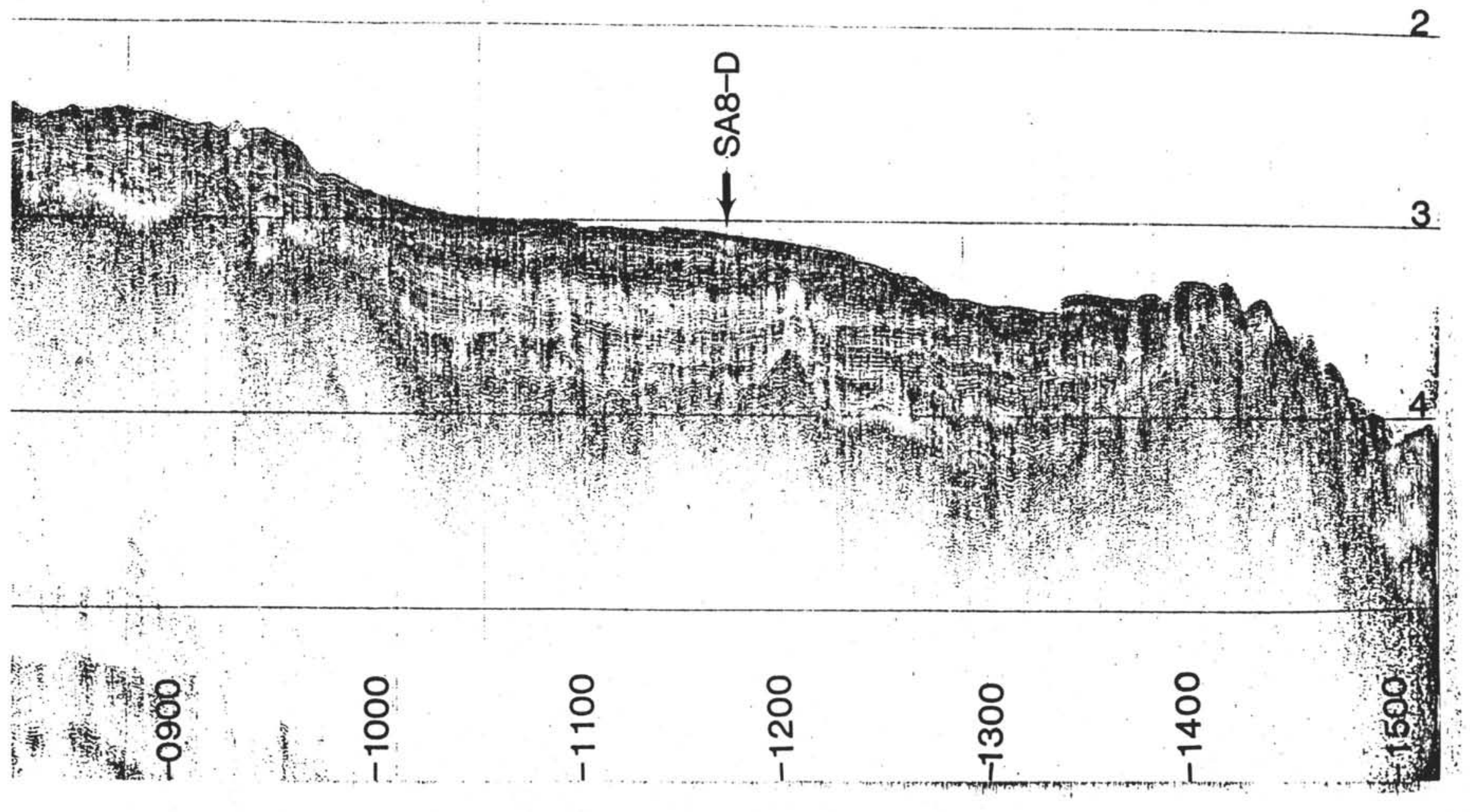




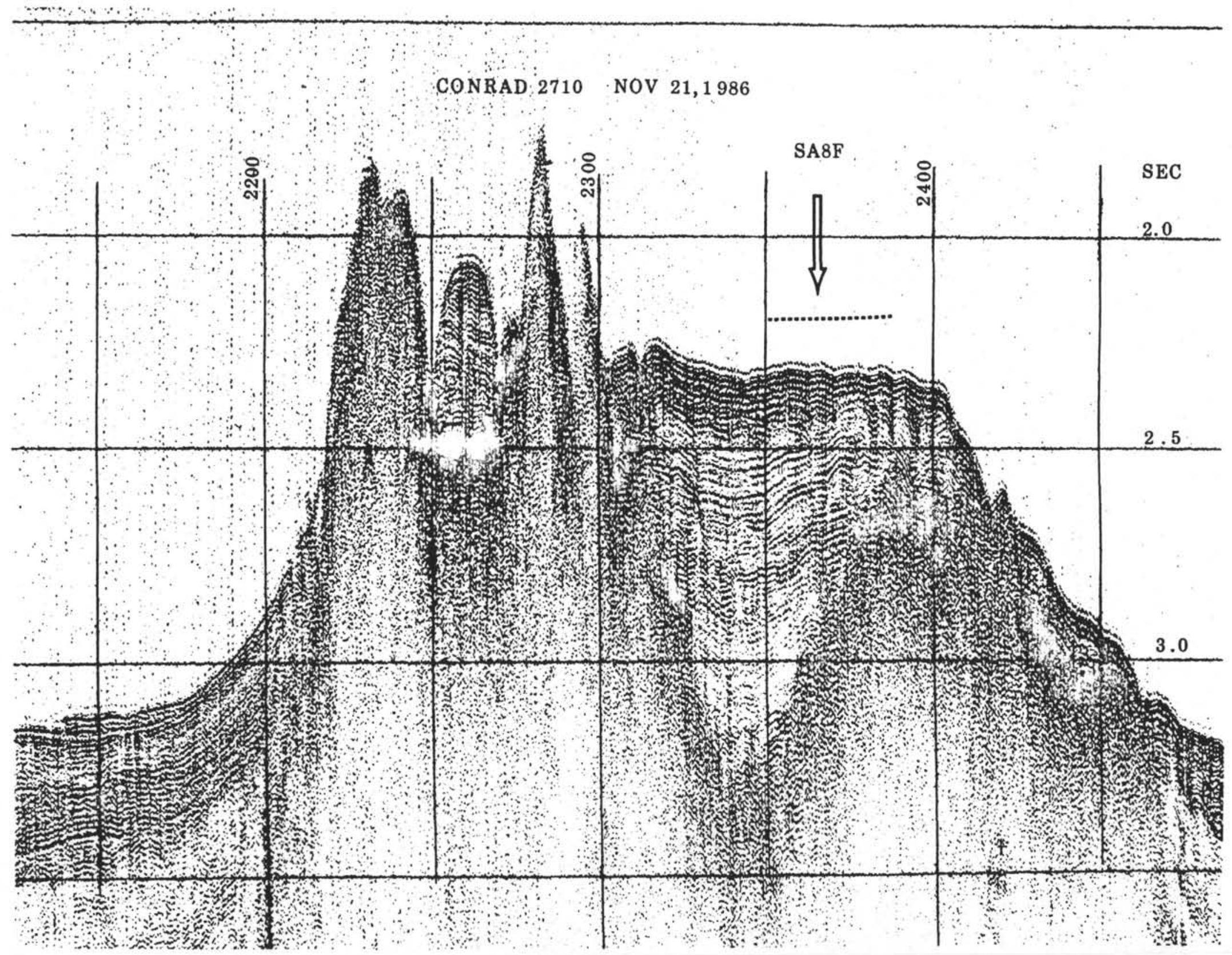




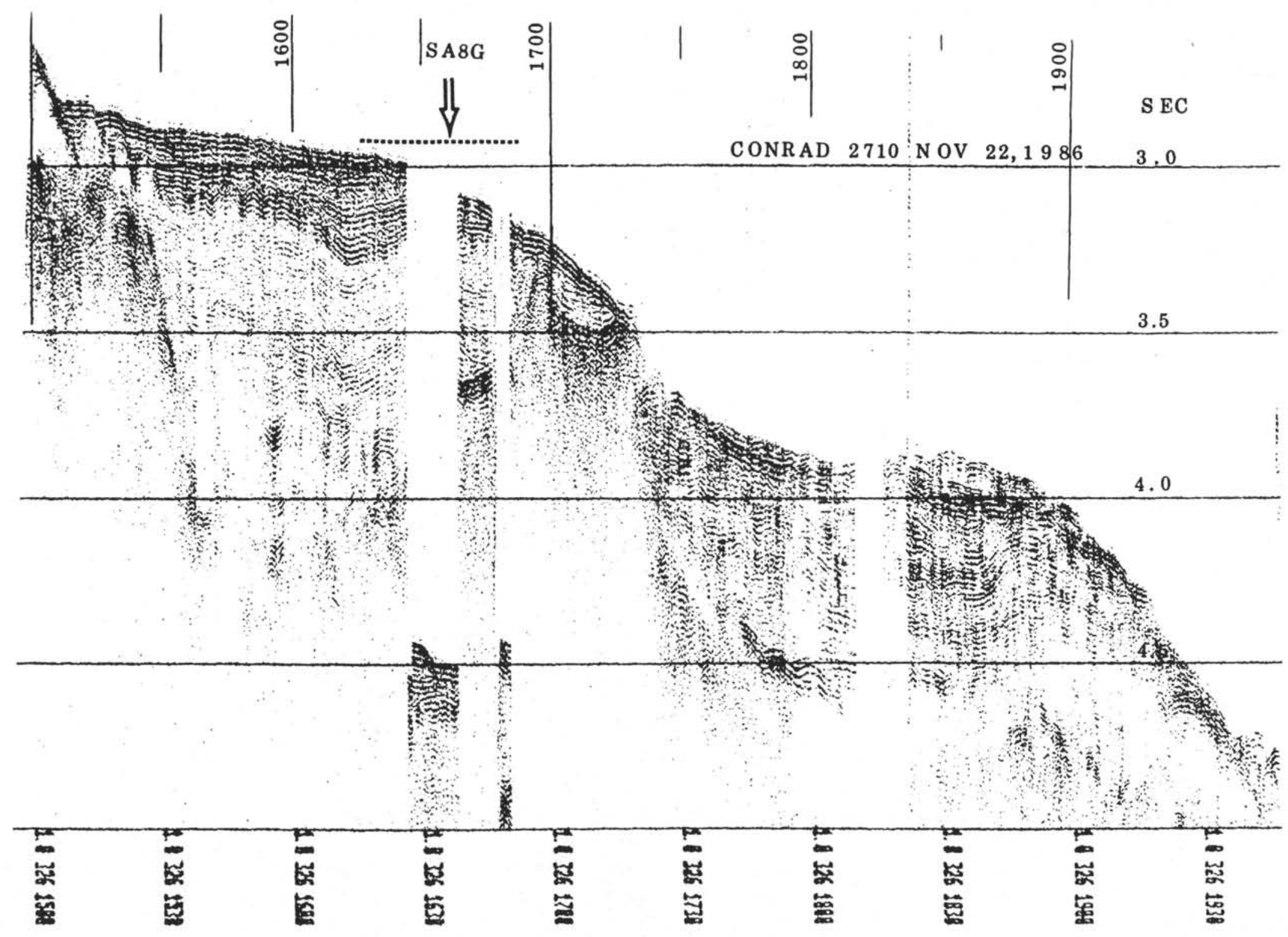

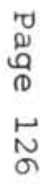




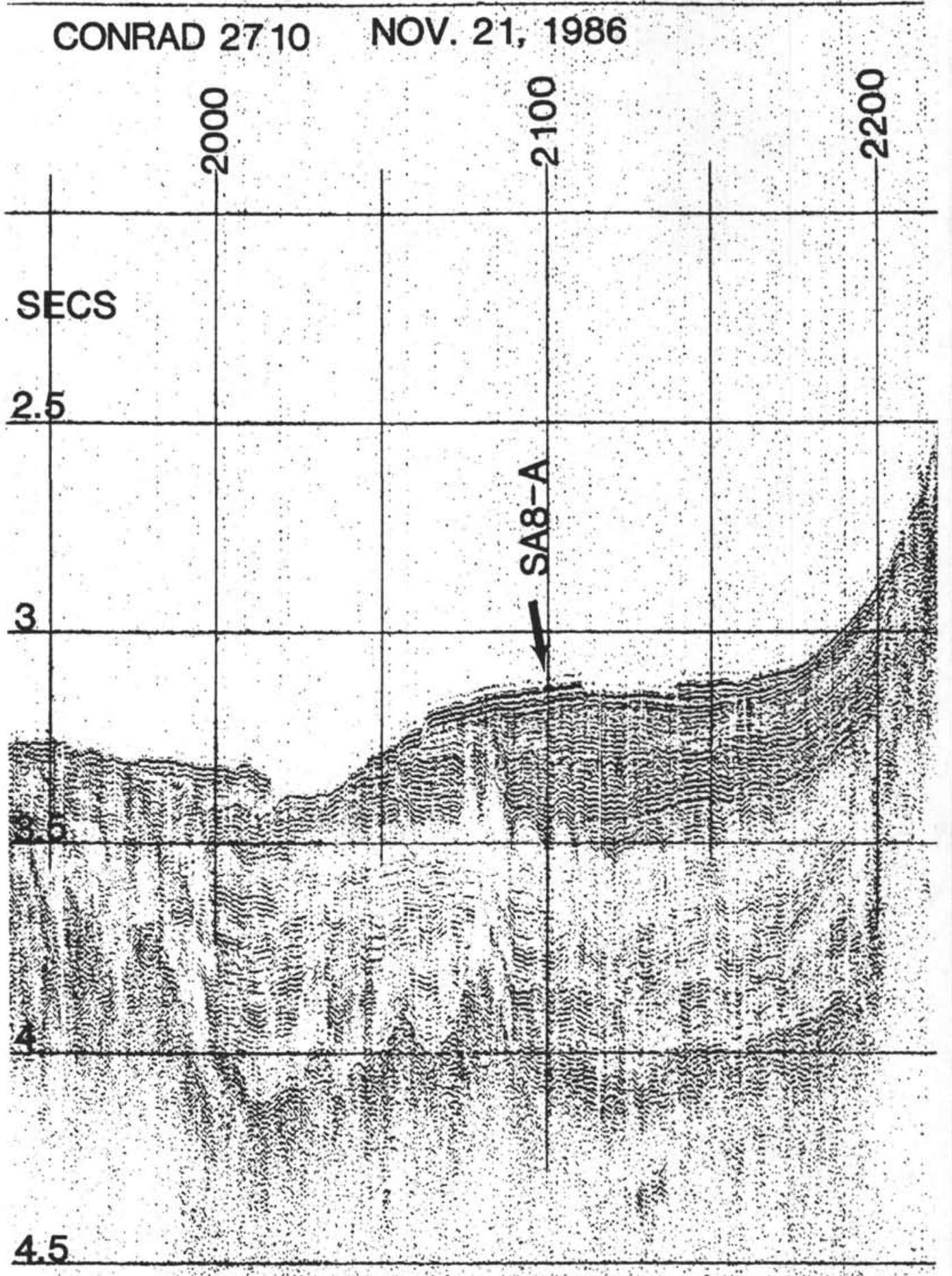


CONRAD 2710 NOV. 21, 1986

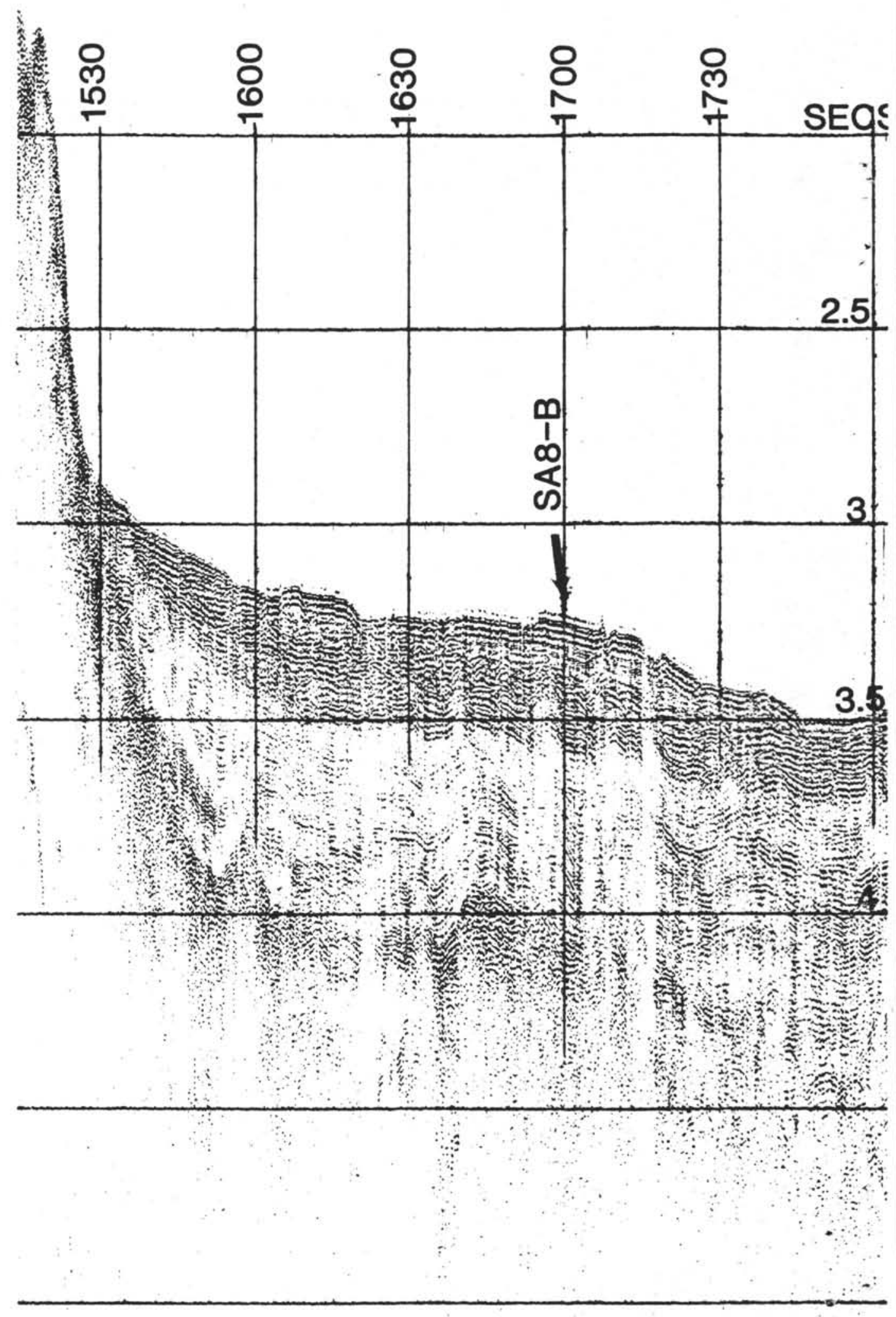


Page 129

CONRAD 2710

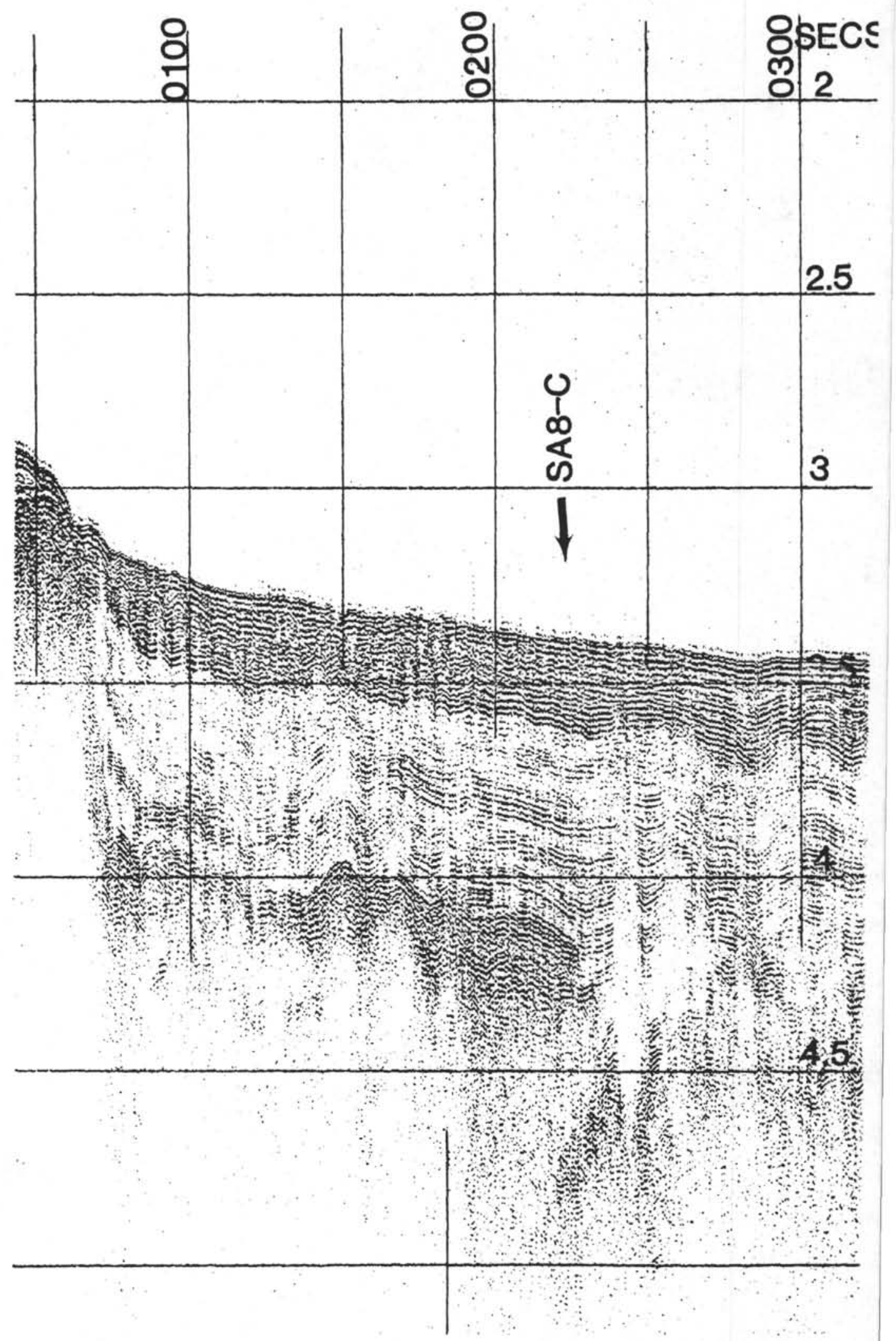


CONRAD 2710 NOV. 20, 1986

\section{SECS}

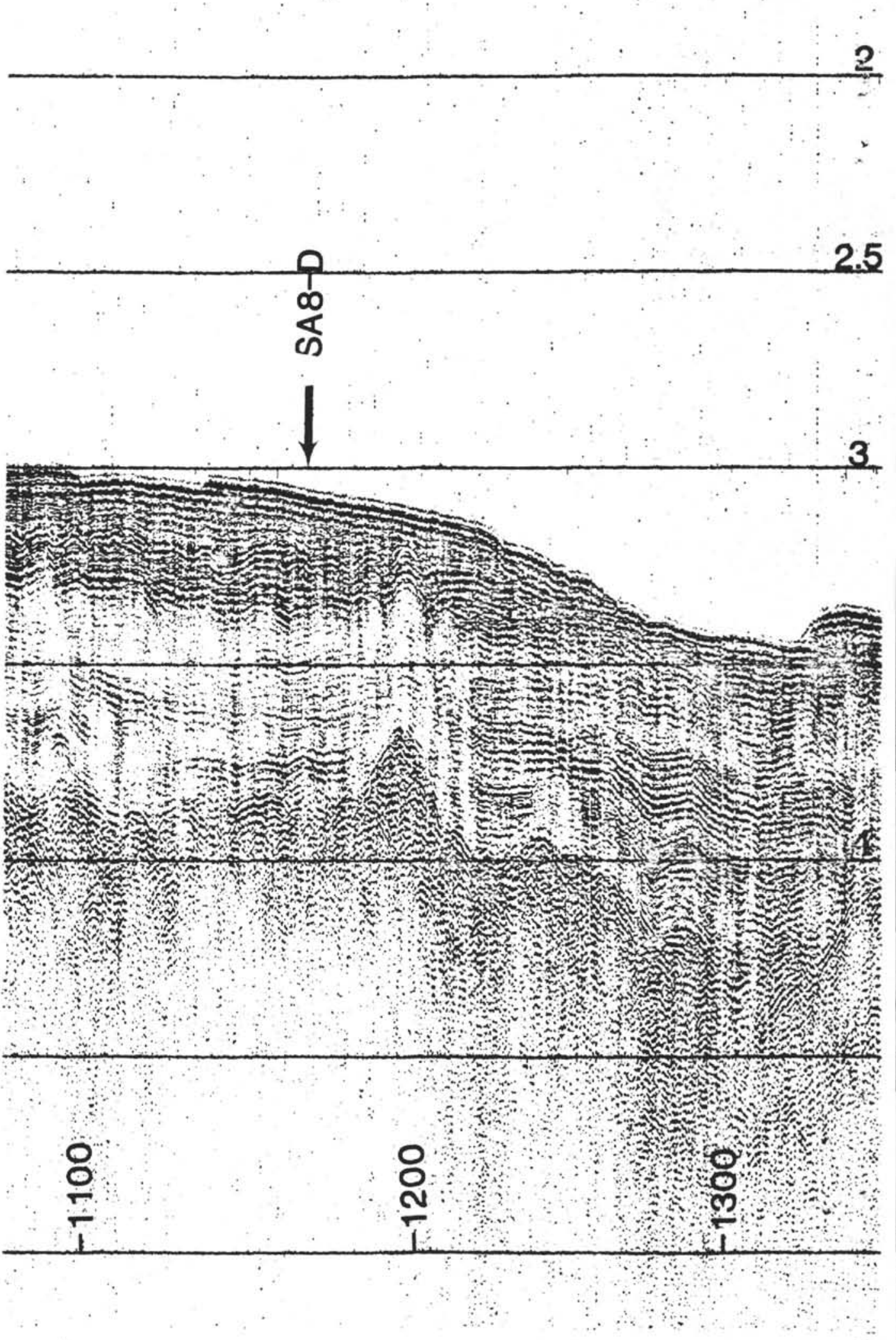


Co-Chief Scientist:

Co-Chief Scientist:

ODP Staff Scientist/

Paleomagnetist:

Sedimentologist:

Sedimentologist:

Sedimentologist:

Sedimentologist:
-PAUL F. CIESIELSKI

Department of Geology University of Florida Gainesville, Florida 32611

JQHN LABRECQUE

Lamont-Doherty Geological KRISTOFFERSER Observatory

Palisades, New York 10964

- BRAD CLEMENT

Ocean Drilling Program

Texas A\&M University

College Station, TX 77840

- ROBERT BOURROUILH

Lab. Geologie-Sedimentologie Comparee et Appliquee

Faculte des Sciences

Universite de Pau

Avenue de l'Universite

64000 Pau

FRANCE

- DAVID A. HODELL

Department of Geology

University of Florida

Gainesville, Florida

32611

- DANIEL MULLER

Geologisches Institut ETH-Zentrum

$\mathrm{CH}-8092$ Zurich

Switzerland

currently at:

Department of Geology

University of Florida

Gainesville, Florida

32611

- DETLEF WARNKE

Department of Geological Sciences California State University

Hayward, California

94542 
Sedimentologist:

Sedimentologist/

Inorgan. Geochem:

Physical Properties:<smiles>CCOCC(C)C1CCCCC1C</smiles>

Physical Properties:

Paleomagnetist:

Paleontologist:

(Nannofossils)

Paleontologist:

(Diatoms)

Paleontologist:

(Benthic Foraminifers)
FRANCES WESTALL

Alfred Wegener Institut

Postfach 120161

Columbusstrasse

D-2850 Bremerhaven

F.R.G.

PHILIP FROELICH

Lamont-Doherty Geological

Observatory

Palisades, New York 10964

YNGVE KRISTOFFERSEN

Seismological Observatory

University of Bergen

Allegaten 41

5000 Bergen

Norway

DAVID C. NOBES

Department of Earth Sciences

University of Waterloo

Waterloo, Ontario

Canada N2L 3G1

ERNEST A. HAILWOOD

Oceanography Department

Southampton University

SO9 $5 \mathrm{NH}$

United Kingdom

JASON CRUX

Stratigraphy Branch

BP Research Centre

Chertsey Road

Sunbury-on-Thames

Middlesex, Tw16 7LN

United Kingdom

JULIANE FENNER

Geologisch-Palaontologisches Inst.

der Universitat Kiel

Olshausenstr. 40-60

D-2300 KIEL

F.R.G.

MIRIAM F. KATZ

Lamont-Doherty Geological

Observatory

Palisades, New York

10964 
Paleontologist:

(Radiolarians and Ebridians)

Paleontologist:

(Planktonic Foraminifers)

Paleontologist:

(Planktonic Foraminifers)

Logging Scientist:

LDGO Logging Scientist:

Operations Superintendent:

Special Tools Engineer:

Laboratory officer:

Curatorial Representative:

Yeoperson:
HSIN YI LING

Department of Geology

Northern Illinois University

DeKalb, Il.

60115

MARISA NOCCHI

Department of Earth Sciences

Via Santini 6

Perugia, Italy

DOUGLAS F. WILIIAMS

Department of Geology

University of South Carolina

Columbia, s.c.

29208

CAMPBELL J. MWENIFUMBO

Geological Survey of Canada

601 Booth Street

Ottawa, Ontario

Canada K1A OE8

JEAN-PIERRE BLANGY

Dept. of Geophysics

Stanford University

Stanford, Ca. 94305

MIKE STORMS

Ocean Drilling Program

Texas A\&M University

College Station, TX 77840

FREDERIC YOUNG

Ocean Drilling Program

Texas A\&M University

College Station, TX 77840

TED GUSTAFSON

Ocean Drilling Program

Texas A\&M University

College Station, TX 77840

DAN QUOIDBACH

Ocean Drilling Program

East Coast Repository

Palisades, N.Y. 10964

MICHIKO HITCHCOX

Ocean Drilling Program

Texas A\&M University

College Station, TX 77840 
Shipboard Computer

Systems Manager:

X-ray Technician:

Chemistry Technician:

Chemistry Technician:

Photographer:

Electronics Technician:

Electronics Technician:

Paleomagnetics Technician:

Marine Technician:

Marine Technician:

Marine Technician: (Thin section/paleo tech)
JOHN EASTLAND

Ocean Drilling Program

Texas A\&M University

College Station, TX 77840

CHRISTIAN SEGADE

Ocean Drilling Program

Texas A\&M University

College Station, $\mathrm{TX} 77840$

MATT MEFFERD

Ocean Drilling Program

Texas A\&M University

College Station, TX 77840

JOE POWERS

Ocean Drilling Program

Texas A\&M University

College Station, $\operatorname{TX} 77840$

CHRISTINE GALIDA

Ocean Drilling Program

Texas A\&M University

College Station, $\mathrm{Tx} 77840$

MIKE REITMEYER

Ocean Drilling Program

Texas A\&M University

College Station, TX 77840

B HRRY WEBER

Ocean Drilling Program

Texas A\&M University

College station, TX 77840

SKIP HUTTON

Ocean Drilling Program

Texas A\&M University

College Station, TX 77840

MARK NESCHLEBA

Ocean Drilling Program

Texas A\&M University

College Station, TX 77840

DON SIMS

Ocean Drilling Program

Texas A\&M University

College Station, TX 77840

KEVIN ROGERS

Ocean Drilling Program

Texas A\&M University

College station, TX 77840 


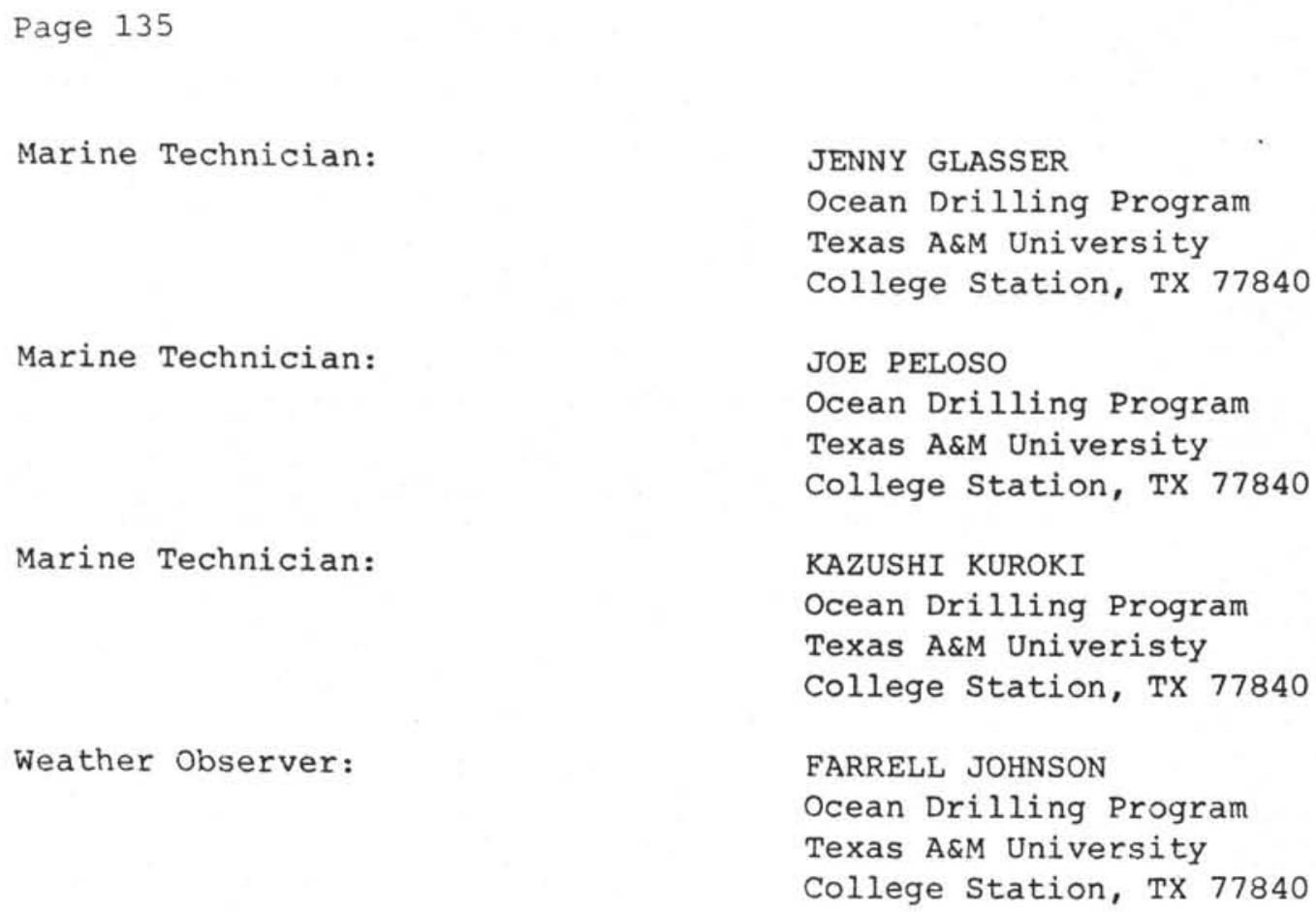

